\title{
CONSEJEROS DE ÓRDENES. PROCEDIMIENTO DE DESIGNACIÓN (1598-1700)*
}

por

\section{RICARDO GÓMEZ RIVERO}

Universidad Miguel Hernández de Elche (Alicante)

RESUMEN: En el artículo se analiza el procedimiento de nombramiento de los consejeros de Órdenes bajo los reinados de Felipe III, Felipe IV y Carlos II. El rey es quien decide los nombramientos de una de las dos maneras siguientes: directamente utilizando el mecanismo del decreto, o bien resolviendo una consulta que formula el Consejo de la Cámara. También se estudia como influyen en esos nombramientos los validos duque de Lerma y conde-duque de Olivares. Finalmente se ve cómo durante el reinado del último monarca de los Austrias se fija una nueva estructura del Consejo de Órdenes, aunque no será respetada por el monarca ya que nombrará consejeros supernumerarios, esto es, no regulados en la planta.

Palabras clave: Consejo de Órdenes. Consejo de la Cámara. Siglo XVII. Nombramientos.

ABSTRACT: This article analyses the process of appointment of the members of the Council of Orders advisers in the reigns of Philip III, Philip IV and Charles II. It is the king who decides upon the appointments in one of the two following ways: directly using the mechanism of royal decree, or instead making use of a brief drawn up by the Consejo de la Cámara. The article also studies the influence in these appointments of the royal favourites, the duke of Lerma and the count-duke of Olivares. Finally, it explores how in the reign of the last Habsburg king a new structure. for the Council of Orders is established, althought this structure would not be respected by the monarch, who will appoint numerous supernumeraries.

KEY WORDS: Council of Orders. Council and Cámara. Seventeenth century. Appointments.

\footnotetext{
* El presente trabajo se ha realizado dentro del Proyecto de Investigación El Gobierno y sus órganos en la Monarquía de los Austrias, PB 97-0581.
} 


\section{Planteamiento}

Cuando fallece Felipe II en 1598, su hijo hereda el sistema de gobierno mediante Consejos. En la Corte residen trece de esos Consejos: el de Guerra, el de Estado, el de Castilla, el Consejo de la Cámara de Castilla, el Consejo de Italia, de Aragón, de Indias, de Flandes, de Portugal, de Hacienda y los Consejos de la Inquisición, de la Cruzada y de las Órdenes Militares ${ }^{1}$. Se estudia en el presente trabajo a los componentes de este último Consejo y, más en concreto, el modo como llegaron al mismo. El objetivo primordial es analizar el sistema de elección de consejeros por el que se decantaron los reyes a lo largo del siglo XVII.

Dos son los métodos de que se sirvan los monarcas para conseguir estos fines. Uno, cuando resuelvan una consulta de la Cámara de Castilla proponiendo candidatos para las plazas vacantes y, otro, al nombrar directamente al consejero que estiman más adecuado. Creo, y así procurare demostrarlo, que tanto Felipe III como su hijo Felipe IV se valieron de la Cámara a la hora de nombrar a los consejeros de órdenes. En cambio, Carlos II hará uso frecuentemente de una forma más expeditiva: antes que la Cámara propusiera candidatos se adelantaba a ella designando mediante decreto.

Otra finalidad que persigo es averiguar cuántos consejeros de este tipo habían desempeñado con anterioridad empleos en alguna Audiencia o Chancillería. Como se verá, salvo un puñado de casos, todos los demás consejeros procedían de la carrera judicial.

Por último, me ha parecido interesante incorporar al final del trabajo, como demostrativo de lo expuesto en él, un extracto de las consultas del Consejo de la Cámara así como unos apuntes biográficos de los distintos consejeros².

\section{FELIPE III. NOMBRAMIENTO DE CONSEJEROS DE ÓRDENES PREVIA CON- SULTA DE LA CÁMARA}

Es conveniente expresar antes que nada, que los Reyes Católicos se habían atribuido la administración de los maestrazgos de las tres órdenes de Santiago,

\footnotetext{
1 TOMÁS Y VALIENTE, F.: «El Gobierno de la Monarquía y la administración de los reinos en la España del siglo XVII», en Obras Completas, Madrid, 1997, T. V, 3803; PARKER, G.: La gran estrategia de Felipe II, Madrid, 1998, 66-68 y EsCuDERO, J.A.: Felipe II: el rey en el despacho, Editorial Complutense, 2002, 36-46. Fuera de la Corte, con sede en Pamplona, residía el Consejo de Navarra (SALCEDo IZU, J.: El Consejo Real de Navarra en el siglo XVII, Pamplona, 1964).

2. Hace más de una década, cuando investigaba en el Archivo Histórico Nacional la Secretaría de Estado y del Despacho de Gracia y Justicia, encontré en la Sección de Consejos un legajo que contenía las propuestas de la Cámara y los decretos de nombramiento de los consejeros de órdenes desde 1588 hasta 1680. Hace poco tiempo —estudiando otra temática y por puro azar- hallé en la Sección de Estado las consultas de la Cámara y los decretos de designación de ese tipo de consejeros a partir de 1680. Esas consultas y esos decretos — desde el inicio del reinado de Felipe III hasta el fallecimiento del último monarca de los Austrias - son los que me propongo estudiar aquí.
} 
Calatrava y Alcántara, «por ser dignidades tan grandes que los que las tenían llegavan a más preheminente autoridad y poder de lo que los Reyes querían»3; y que una real cédula, despachada en Alfaro el 10 de noviembre de 1495, dispuso que el Consejo de Órdenes conocería de los pleitos de las órdenes de Santiago y Calatrava así como de las apelaciones de las sentencias que emitieran los gobernadores y los tenientes de los territorios de aquéllas órdenes 4 .

Según una Relación de los Consejos que su Magestad tiene en su Corte de ordinario y de que se sirve siempres, en 1577 era presidente del Consejo de Órdenes Antonio de Padilla y había cuatro oidores, todos ellos «cavalleros limpios» y adornados con algún hábito de Santiago, Calatrava o Alcántara. El Consejo conocía de los pleitos de los territorios de las órdenes y de la limpieza de los caballeros, competiendo a su presidente en exclusiva proponer al rey candidatos para los corregimientos, vicarías, capellanías y alcaldías de las «provincias» de las órdenes ${ }^{6}$.

Un documento del período que historiamos, custodiado en el mismo archivo que el anterior ${ }^{7}$, menciona las siguientes competencias del Consejo de Órdenes:

1.- Realizar las correspondientes averiguaciones e informaciones para conceder los hábitos a aquellas personas a las que el rey les ha hecho merced de los mismos.

2.- Conocer de los asuntos de justicia de los maestrazgos de Santiago, Alcántara y Calatrava.

${ }^{3}$ En el anónimo Origen de los Consejos de España, su jurisdición y exercicio, sin data, British Library (en adelante BL), Eg. 338, fol. 48 vto. Los autores han dado diversas fechas de creación del Consejo de Órdenes (Véase Postigo Castellanos, E.: Honor y privilegio en la Corona de Castilla. El Consejo de las Órdenes y los Caballeros de Hábito en el siglo XVII, Junta de Castilla y León, 1988, 21-26).

${ }^{4}$ Novísima Recopilación, libro II, título VIII, ley $1^{2}$, nota 2 . Según Tomás y Valiente ese año fue creado el Consejo de Órdenes ( TOMAS Y VALIENTE, «El Gobierno de la Monarquía y la administración de los reinos en la España del siglo XVII», T. V, 3820). En cuanto a las competencias del Consejo de Órdenes, según el documento anónimo citado en nota anterior, administra «la jurisdiçión eclesiástica con que procede en las causas de los cavalleros religiosos y los juzga conforme las definiçiones y establezimientos de las órdenes que todos están confirmados por autoridad Apostólica, Bullas y previlegios, y así mismo la Real y suprema para las causas entre partes que su Magestad fue servido de comunicarle como Rey y señor soberano en lo temporal, a quien perteneçía tanbién en tiempo de los maestres el derecho de la suprema jurisdiçión que es inenagenable y anexo a la soberanía de la Corona». También consultaba el Consejo «los ofiçios mayores de los lugares de las ordenes, las vicarías, prioratos y otros benefiçios eclesiásticos» (BL, Eg. 338, fol. 49 vto.).

5 Custodiada en BL, Harl. 3315, fols. 94-128.

${ }^{6} \mathrm{BM}$, Harl. 3315, fol. $96 \mathrm{r}^{\circ}$. En otro documento, también de BL, Sloan, 3610, fols. 8 vto.15 vto., Relación de los Consejos que su Magestad tiene en la Corte de ordinario y de que se sirve siempre, se recoge básicamente lo anterior y añade la composición del Consejo de Órdenes en 1604. Véase EsCUDERO, J.A.: «La Corte de España en Valladolid: los Consejos de la Monarquía a principios del siglo XVII", en Administración y Estado en la España Moderna, Junta de Castilla y León, 1999, 494.

7 Relación puntual de todos los Consejos y Tribunales supremos que residen de ordinario en la Corte de España, y las Chancillerías y Audiencias que ay en ella, con las de las Indias Occidentales, y el número de plaças y oficiales que cada una tiene y de lo que se trata, en BL, Add. 10.236, fols. 421-458. 
3.- Proponer al rey, de un lado, candidatos para los gobiernos, beneficios, prioratos y dignidades de las tres órdenes militares y, de otro, jueces para residenciar a los gobernadores y pesquisidores que castiguen a los que cometan delitos en los territorios de las órdenes militares 8 .

Como se observa claramente, entre esas competencias no se encuentra la de proponer candidatos para las plazas de consejeros de órdenes. Es la Cámara, que se institucionaliza en 1588 , el órgano encargado de someter a la consideración del rey la consulta, en la que consta la relación de candidatos a las vacantes del Consejo de Órdenes.La reorganización del sistema de trabajo del Consejo de la Cámara operada por Felipe II en 1588 cambiará radicalmente a partir de entonces los trámites de la provisión de muchas plazas de jueces y de magistrados. Para implantar el nuevo método de provisión, Felipe II se había asesorado de su secretario personal Mateo Vázquez. Cuando en 1591 fallezca Vázquez, el monarca resolverá todas las consultas de la Cámara directamente9. Interesa destacar que Felipe II nunca omitió el trámite de la previa consulta de la Cámara a la hora de nombrar a los jueces y magistrados, cosa que sí que harán — como veremos-los sucesivos monarcas.

Felipe II fallece el 13 de septiembre de 1598 . El régimen personalista que encarnaba será «sustituido por un modelo distinto de gobierno, en el que el favorito del nuevo rey, don Francisco Gómez de Sandoval, marqués de Denia, asume un papel crucial en el proceso de toma de decisiones; interponiéndose entre el trabajo de las secretarías y la voluntad soberana, orientando las consultas de los Consejos y controlando el patronazgo» ${ }^{10}$. Más adelante tendré ocasión de hablar de la relación del valido con el Consejo de la Cámara.

Apenas fallezca Felipe II, el nuevo rey designa al marqués de Denia como consejero de Estado. En efecto, el cronista de Felipe III y de Felipe IV González Dávila relata que la «primera cosa que hizo el nuevo Rey (Felipe III) en la primera hora de su Reynado fue declarar en gracia a D. Francisco Gómez de Sandoval, Marqués de Denia, Grande de España y su Caballerizo Mayor, mandando que jurase de su Consejo de Estado, entregándole el despacho de su Imperio ${ }^{11}$.

8 BL, Add., 10.236, fol. 430. Véanse las competencias de este Consejo en dos cronistas del siglo XVII: GonZÁlez DávilA, G.: Teatro de las Grandezas de la Villa de Madrid, Madrid, 1623 (manejo la edición facsímil, El consultor de los ayuntamientos, Madrid, 1986, 485) y NúÑEZ DE CASTRO, A.: Sólo Madrid es Corte, Madrid, 1675, 78-82.

9 Gómez RIvero, R: "Consejo de la Cámara (1588-1598)», en AHDE, T. LXX (2000), 125-194.

10 BENIGNO, F.: La sombra del rey, Madrid, 1994, 39.

11 González Dávila, G.: Monarquía de España. Historia de la vida y bechos del ínclito monarca, amado y santo D. Felipe Tercero, Madrid, 1771, 39-40. Tomás y Valiente expresa tajantemente: «Lerma no fue ni siquiera consejero de Estado» (TOMÁs Y VALIENTE, F.: Los validos en la monarquía española del siglo XVII, $2^{\text {a }}$ ed., Madrid, 1990, 80). Lerma, según Elliott, a "pesar de ser consejero de Estado, raramente asistía a sus sesiones, pues prefería ejercer el poder entre bastidores» (ELLIOTT, El conde-duque de Olivares, 56). 
Felipe III aceptó de buen grado el mecanismo de funcionamiento de la Cámara heredado, si bien realizó algunos pequeños cambios en la forma de proponer y en el estilo de los membretes de las consultas. Un oficial público, cuyo nombre desconocemos, escribirá al rey a comienzos de su reinado, planteando reformas respecto de una serie de asuntos, en especial, sobre el método de concesión de mercedes ${ }^{12}$. En cuanto a las propuestas del Consejo de la Cámara, opinará que se vuelva al sistema que imperaba con anterioridad a 1588, cuando los presidentes del Consejo de Castilla proponían a los candidatos para las vacantes de los oficios, sin necesidad de contar con el voto de los camaristas. El anónimo autor sugería al rey que eligiera a un presidente - el «offiçio de mayor importançia destos Reynos», dirá- solvente, prudente y con autoridad ${ }^{13}$.

En una carta fechada en Madrid el 14 de septiembre de 1598, esto es, el día siguiente a la muerte de Felipe II, el Nuncio Camillo Caetani decía al cardenal Pietro Aldobrandini: «Subito che fu morto il Re, il Pincipe se serro solo con il Marchese di Denia (...) Il Marchese di Denia cinque hore doppò la morte del Re fu fatto del Conseglio di Stato». En otra carta del 30 del mismo mes vuelve a insistir el nuncio sobre el nombramiento del duque de Lerma como consejero de Estado: «El mismo día que murió Su Magestad —escribía Caetani a Aldobrandini--, por la tarde el nuevo Rey juntó a Consejo de Estado al Arçobispo de Toledo, Don Christóbal de Mora y a Don Juan de Idiáquez y el Marqués de Velada, y a los Condes de Fuensalida y Chinchón y hizo del dicho Consejo al Marqués de Denia desde quando se començó a declarar su mucha privanza» [VARGAS HIDALGO, R: «Documentos inéditos sobre la muerte de Felipe II y la literatura fúnebre de los siglos XVI y XVII», en Boletín de la Real Academia de la Historia, T. CXIII, cuaderno III (sep.-dic. 1995), 430 y 433 ].

El embajador de Toscana en Madrid, Francesco Guicciardini, expresaba que el marqués de Denia fue designado con sejero de Estado a las seis horas de expirar Felipe II ( C. SECO SERRANO, «Los comienzos de la privanza de Lerma según los embajadores florentinos», en Boletín de la Real Academia de la Historia, T. CXLIV (1959), Cuaderno I, 78).

12 «Papel dado a Felipe III sobre advertencias y prevenciones para comenzar bien su reinado.1598", custodiado en la Biblioteca Nacional de Madrid e inserto en Mss. 2346, Sucesos de los años 1598 a 1600, fols. 23-30. Sabemos que es un servidor público por que al final del papel se dice: : «El amor, y zelo, con que he deseado servir en lo pasado (de que con liçençia de V.M de le daré cuenta) con la obligación de la fidelidad, y juramento que hize : y mayor desseo que tengo de continuar mis serviçios, me han obligado, a servir a V.M. ${ }^{\mathrm{d}}$. con este pobre cornado de mi caudal, en el prinçipio de su gobierno». La referencia en el fol. $30 \mathrm{r}^{\circ}$

13 Lo expresará así: «Para una parte de la justicia distributiva, que es hacer merced, tiene V.M ${ }^{d}$. su Consejo de Cámara, donde se trata y resuelve, en qué casos, y a qué personas se debe hacer merced, con tal conoçimiento de causa y justificaçión que sería agravio no hacerla (...).

El remedio que tiene lo passado, es, ponerle en lo porvenir: mandando V. $\mathrm{M}^{\mathrm{d}}$. que tenga diferente cuidado que hasta aquí en las elecciones que se huvieren de hazer, para que siendo posible, se escojan, como dixo Moysen los mejores de todo el pueblo, varones, sabios, temerosos de Dios, llenos de cuydado, y amor de la justiçia y enemigos de todo género de avariçia.

Considerando mucho si para esto convendrá que se continue hazerlas Presidente y los de la Cámara, como ahora se hace, o reduzirlo a solo el Presidente, como se hazía antes. Porque aunque es verdad que obliga a la novedad que se hizo, el deseo de remediar algunas malas provisiones que se hazían, pero la experiencia ha mostrado, que no se ha salido con el, como se pretendía, sino que ha sido, y es muy mayor el daño, como es notorio por el estado que tienen todos los tribunales, y sentimiento que ay de las más personas que se ponen en ellos.

Hispania, LXIII/2, núm. 214 (2003) 657-744 
En opinión de Postigo, tres eran como mínimo los requisitos exigidos a los futuros consejẹros de órdenes: nobleza y limpieza de sangre, tener un hábito de alguna de las órdenes militares de Santiago, Alcántara y Santiago y ser letrado ${ }^{14}$. A Gregorio de Tovar, consejero de órdenes desde 1626 hasta su fallecimiento, le preocupaba seriamente el tema de la limpieza de sangre. Era cofrade del hospital de nuestra Señora Santa María de Esgueva (Valladolid) y al respecto expresa en su autobiografía ${ }^{15}$ :

Este daño es más dificultoso de remediar, siendo la elección de muçhos, porque cada uno quiere favoreçer a sus cossas, parientes, y amigos, neçesariamente ha de ser mayor el daño, mientras fueren más, y también, porque desta manera la culpa, es, de todos sin poderse hazer cargo della a ninguno.

Multiplícase más este ynconveniente porque: como la consulta que haze la Cámara va a la Junta, y esta haze otra nueva : La Cámara dize, que no es suya la culpa, y la Junta dize, lo mismo, y con esto, la República y el servicio de V.M ${ }^{d}$. queda condenado a tener el ministro que no conviene, pues es la mayor pena que se le puede dar.

Pareçe que se le remediará todo, a lo menos para que sea del mal lo menos, siendo V.M. ${ }^{\mathrm{d}}$. servido de mandar que en materia de offiçios no consulte sino sólo el Pressidente de Castilla, siendo el que conviene: como se experimentó quando lo fueron, Juan de Vega Fonseca, el Marqués de Mondéjar, Figueroa, y Spinosa, cada uno de los quales en su tiempo tuvieron los tribunales llenos de personas las más insignes, en letras, prudençia y las demás partes que había en estos reynos.

$\mathrm{Y}$ porque los suçesores destos ayan declinado, como es çierto que lo han hecho, no por esto devió pagar su culpa el offiçio que no la tuvo.

Antes lo que conviene es, poner mayor cuidado, en que este offiçio tenga la autoridad que siempre tuvo, y si fuere posible mayor. Ansí porque la persona a quien se encarga es la principal de quien V.M ${ }^{d}$. confía toda la justiçia destos Reynos, como porque le pone para que sea medio entre $\mathrm{V}$. $\mathbf{M}^{\mathrm{d}}$. y todos sus vasallos, para oir, responder, y satisfazer a cada uno que la pidiere.

$\mathrm{Y}$ ansí lo que prinçipalmente conviene, es escoger siempre para Presidente de Castilla persona que tenga tanto crédito, y auctoridad, por su virtud, prudençia y grandes partes, y por la notoria experiençia que se tuviere de su vida, y costumbres immaculadas, como por razón del offiçio que se le diere: porque siendo tal, entenderá lo que se le da y reçibe, y para que effecto : y entendiéndolo será çierto, que no le convertirá en sí mismo, y en sus fines particulares, sino en cumplir con el serviçio de Dios, y de V.M ${ }^{d}$. consigo mismo y con el bien universal destos Reynos : sin acordarse, que ai más carne ni sangre.

Quien tuviere por dificultoso hallar persona tal, y de tanta confiança como, confieso que lo es, y más, en tiempo tan estéril: con razón tendrá por mas dificultoso hallar quatro que sean tales, como verdaderam $^{\text {te }}$. lo han de ser, sin que entre el Presidente y los de la Cámara aya poca, o ninguna diferençia, a lo menos para que se pueda conservar, la orden que agora ay en las elecçiones de offiçios.

De todas maneras pareçe que por ser este offiçio de la Presidençia de Castilla el de mayor importançia destos Reynos para descargo de la real conçiençia de V.M ${ }^{\mathrm{d}}$. quanto a lo de la justiçia que está tan a su cargo, conviene que siendo qual queda representado esté siempre muy favoreçido y benefiçiado, para que se halle más obligado a cumplit como debe.

Entre las cossas de que ha de tener mayor cuydado el Presidente es, que las cabeças que se pussieren por Virreyes y otros Gobernadores, fuera destos Reynos y Presidentes en los tribunales dellos sean de grande auctoridad, adquerida con exemplo, y vida, y reprehensible prudençia, y otras partes, con que verdaderamente sepa y pueda velar sobre los demás, procurando que sean tales quales conviene al serviçio de Dios y de V. M $\mathbf{M}^{\mathrm{d}}$. y que de los que no lo fueren den luego cuenta a V. $\mathbf{M}^{\mathrm{d}}$.» (fols. 25-26).

14 Postigo Castellanos, Honor y privilegio en la Corona de Castilla, 87-88.

15 Vida y memorias del Licenciado D. Gregorio de Tovar, ms. 19344 de la BNM. Algunos aspectos de la misma fueron tratados por PAZ y MELIÁ, A.: «Un jurisconsulto del siglo XVI pintado por sí

Hispania, LXIII/2, núm. 214 (2003) 657-744 
«adonde no puede ser ni entrar ninguno por cofrade ni a ella ser admitido si no es siendo limpio por todos los dieciséis costados de toda mala raza de judíos o moros o penitenciados por el Santo Oficio de la Inquisición (...) en la cual (cofradía) el número es de treinta cofrades sin que en ella puedan en un tiempo serlo padre e hijo, ni dos hermanos, ni dos cuñados, y ansí los cofrades que allí hay son los mejores y de más limpia sangre de todo Valladolid» ${ }^{16}$.

A la hora de elegir a su mujer, Francisca de Guevara, Tovar tuvo en cuenta su limpieza: «limpia y accesoriamente que fuese hermosa y rica» ${ }^{17}$.

En 1602 el rey ordenará que la Cámara proponga para cada oficio de justi$\mathrm{cia}^{18}$ una terna y cuando hubiera empate en la votación de los candidatos, el presidente del Consejo de Castilla tendría voto de calidad ${ }^{19}$. Hasta entonces era normal que en las consultas figurasen hasta seis aspirantes ${ }^{20}$.

mismo", en Revista de Arcbivos, Bibliotecas y Museos, enero-febrero (1908). Tovar escribió un Repertorio de las Partidas. Su abuelo, Gregorio López de Córdoba y Valenzuela fue editor de Las Partidas (PELORSON, J.-M.: Les Letrados, juristes castillans sous Pbilippe III. Recherches sur leur place dans la société, la culture et l'État, Poitiers, 1980, 144). Erra Pelorson cuando expresa que Tovar presidió la Chancillería de Valladolid en 1619 (véase MARTIN POSTIGO, M. DE LA S.: Los presidentes de la Real Chancillería de Valladolid, Valladolid, 1983, 136-137).

16 Pelorson, Les Letrados, 199. Sobre esta cofradía véase AlONSO CORTÉs, N. «Los cofrades de Santa María de Esgueva», en Miscelánea Vallisoletana, 2 (1955), 197-300.

17 Pelorson, Les Letrados, 199.

18 Como acertadamente señaló Tomás y. Valiente son oficios que llevan «incorporado poder jurisdiccional en sentido estricto, es decir, administración de justicia por vía contenciosa entre partes, tanto si se intervenía a título de juez como si la intervención no era decisoria (caso de los fiscales). Desde los simples corregidores hasta los consejeros de Castilla recibían su título tras haber sido consultado y despachado por esa secretaría de la Cámara de Castilla» (TOMAS Y VALIENTE, «El Gobierno de la Monarquía y la Administración de los Reinos en la España del siglo XVII», Obras completas, T.V, 3817-3818).

19 Resolución a la consulta del Consejo de la Cámara de 3 de octubre de 1602 [AHN, Estado, leg. 6408. Véase además FAYARD, J.: Los miembros del Consejo de Castilla (1621-1746), Madrid, $1982,85-86]$.

20 Véase, a este respecto, el anexo final. También ocurría igual en los últimos años del reinado de Felipe II. Como ejemplo cito la consulta de 20 de agosto de 1589 en que la Cámara había propuesto al rey cinco candidatos para una plaza del Consejo de Órdenes, vacante por promoción de Santoyo de Molina a consejero de Castilla. Los sujetos propuestos eran:

1.- El presidente del Consejo de Castilla y los camaristas Guardiola y Gómez «nombraron»:

a) Figueroa Maldonado, oidor de la Chancillería de Valladolid.

b) Antonio Sirvente de Cárdenas, oidor de la Chancillería de Granada . Ex colegial del colegio de Cuenca en Salamanca, en cuya Universidad desempeñaría una cátedra de cánones. La Cámara expresaba que Sirvente era «buen letr ${ }^{\mathrm{do}}$. y de buen entendimy ${ }^{\circ}$., virtuoso y recogido y buen juez, entero y que asiste con mucha diligençia y cuydado a su ofiçio y proçede en él con satisfaçión, es hijodalgo y limpio y no es casado».

2.- De otro lado, el presidente propuso a los dos siguientes jueces:

a) Cervantes de Gaete, oidor de la Chancillería de Granada. Juez «entero y buen letrado, cuerdo y de muy buen entendimy ${ }^{\circ}$. y tiene de comer y él y su muger las calidades de nobleza y limpieza que se requieren para esta plaça». 
A partir de aquél año el mecanismo de funcionamiento de la Cámara será del siguiente modo. El presidente y los tres camaristas se reunirían dos horas las tardes de los lunes y miércoles ${ }^{21}$. Para la validez de los acuerdos bastaba con la asistencia de dos miembros. En cuanto a los trámites para la provisión de plazas de los Consejos, Audiencias y corregimientos eran de la forma siguiente. Los que pretendan alguna plaza vacante elevan sus solicitudes al rey, quien a su vez las remite al presidente de Castilla. Este se encarga de señalar día para votar. El orden de votación es según la antigüedad en el cargo del Consejo Real — no de la Cámara - votando en primer lugar el consejero más moderno y asî sucesivamente. El último en votar será el presidente, que tiene voto de calidad. Para cada plaza vacante de oficio de justicia se propondrá una terna.

El secretario de Justicia se ocupa de tomar nota de las votaciones y luego en su casa redactará la minuta de la consulta. Consejeros de la Cámara y su presidente verán la minuta por si desean cambiar su parecer. Una vez redactado el original de la consulta ${ }^{22}$, los intervinientes se encargan de rubricarlo en sus casas. A continuación el presidente envía la consulta al rey, quien finalmente resuelve.

Felipe III escribiría de su puño y letra todas las respuestas a las consultas del Consejo de la Cámara ${ }^{23}$. Las resoluciones, unas veces anotadas al margen de esas consultas y otras en el membrete de las mismas, van rubricadas por el monarca que, en pocas ocasiones designará consejeros de órdenes o de castilla sin tener en cuenta la previa opinión de la Cámara ${ }^{24}$.

En las consultas, además de reflejar los estudios realizados y la actividad profesional desempeñada ${ }^{25}$, se resalta el parentesco de los candidatos propuestos con personajes influyentes de la Corte o que prestaron servicios a la Coro-

b) Doctor Calderón, del Consejo de Navarra. Era letrado «virtuoso y concurren en él y en su muger las otras partes y calidades neçesaryas de nobleza y limpieza para esta plaça».

3.- Los camaristas Gómez y Guardiola propusieron a Francisco de Contreras, oidor de la Chancillería granadina. Con anterioridad había ocupado una plaza en el Consejo de Navarra. Procedía del colegio de Oviedo de Salamanca. Letrado virtuoso, recto y juez entero; tenía «de comer y él y su muger las calidades y que se requyeren para esta plaça». Su mujer era hija del consejero de Castilla Gasca.

Como se puede apreciar, dos de los cinco pretendientes eran colegiales mayores. El rey, teniendo en cuenta la opinión de su secretario privado Vázquez, designó como consejero de órdenes a uno de los dos colegiales: Francisco de Contreras. Lo anterior en AHN, Consejos, leg. 51.708.

${ }^{21}$ Esto y lo que sigue se encuentra en La Orden que se tiene en el Cons ${ }^{\circ}$. de la Cámara es la siguiente, custodiada en Archivo General de Indias, Indiferente General, leg. 855 y que transcribo en el apéndice final. Probablemente sea del año 1603 ya que en ella se habla de la terna que la Cámara deberá presentar obligatoriamente a partir de finales de 1602. Véase al respecto SCHÄFER, E.: $E l$ Consejo Real y Supremo de las Indias, T. I, Sevilla, 1935, 181-182, quien data el documento en 1600 nota 3 de página 180-.

${ }^{22}$ Schäfer habla de copia (El Consejo Real y Supremo de las Indias, T. I, 181).

23 También en las del Consejo de Estado (BARrios, F.: El Consejo de Estado de la Monarquía Española (1521-1812), Madrid, 1984, 121)

${ }^{24}$ Esto lo analizo en un trabajo que en breve publicaré y que llevará por título Los miembros de los Consejos de Castilla y de la Cámara (1598-1621).

25 RolDÁn Verdejo, R: Los Jueces de la Monarquía Absoluta, Universidad de La Laguna, 1989, 94.

Hispania, LXIII/2, núm. 214 (2003) 657-744 
na $^{26}$. Así, Luis de Padilla era sobrino de Antonio de Padilla, que había ocupado las presidencias de los Consejos de Órdenes y de Indias ${ }^{27}$. Otro sobrino de éste último, Juan Gaitán de Ayala, era hijo de Juan Gaitán, mayordomo del archiduque Alberto, y además sobrino de Diego López de Ayala, consejero de Hacienda, de Castilla y camarista y primo hermano de Luis de Padilla, consejero de Castilla y camarista ${ }^{28}$. Jerónimo Medinilla, yerno de Pedro de Velasco, capitán de la guardia del rey Felipe II ${ }^{29}$. Pedro de Vega, hijo de Hernando de Vega, presidente del Consejo de Indias ${ }^{30}$. Sebastián de Villafañe, su padre había sido consejero de castilla y camarista ${ }^{31}$. Mendo de Benavides, hijo del conde de Santisteban y sobrino de Álvaro de Benavides, del Consejo y Cámara ${ }^{32}$. En fin, Pedro de Álava, cuyo bisabuelo, el licenciado Aguirre, perteneció al Consejo Real y su tío Andrés de Álava, al de la Inquisición ${ }^{33}$.

Este monarca elegirá hasta veintiún consejeros de órdenes: Álvaro de Benavides, Egas Venegas y Antonio Pedrosa, en 1599; García de Medrano, en 1600; Ruy Díaz de Mendoza, Luis de Padilla , Jerónimo de Medinilla y Diego de Salcedo, en 1604; Enrique Pimentel, en 1606; Pedro de Vega, en 1608; Juan Serrano, en 1609; Mendo de Benavides y Alonso de Cabrera, en 1612; Pedro de Álava y Juan Gaitán de Ayala, en 1613; Juan de Coello, en 1614 y Sebastián de Villafañe, Juan Jiménez de Ocón, Luis de Villavicencio y Pedro de Guzmán, en 1616 y el año siguiente Antonio de Castro. Generalmente eran nombrados al responder el rey a alguna consulta de la Cámara. Esta formuló hasta diez consultas para plazas vacantes del Consejo de Órdenes.

En la primera consulta, fechada el 25 de septiembre de 1599, la Cámara proponía candidatos para una plaza que había vacado por promoción de Francisco de Contreras al Consejo Real. Aunque iba propuesto en primer lugar Ruy Díaz de Mendoza, oidor de la Chancillería de Valladolid y con anterioridad de la de Granada, el monarca nombró al segundo colocado, Egas Venegas Girón, también magistrado de lo civil en Valladolid y del que la Cámara expresaba "que antes havía sido ally alcalde de la Chancillería, fue colegial del colegio de Cuenca, en Salamanca y es nieto de Hernando Girón que fue del Consejo del $\mathrm{Emp}^{\text {or }}$. n. $\mathrm{s}^{\mathrm{r}}$., que aya gloria y también es persona en quien concurren muy

${ }^{26} \mathrm{AHN}$, Consejos, leg. 51.708. FAYARD, Los miembros del Consejo de Castilla, 86.

27 Consulta del Consejo de la Cámara, 3-III-1604 (AHN, Consejos, leg. 51.708).

28 Consulta del Consejo de la Cámara, 14-II-1612 (AHN, Consejos, leg. 51.708).

${ }^{29}$ Consulta del Consejo de la Cámara, 31- III-1604 (AHN, Consejos, leg. 51.708)

30 Consulta del Consejo de la Cámara, 20-VI-1605 (AHN, Consejos, leg. 51.708).

31 Consulta del Consejo de la Cámara, 20-VI-1605 (AHN, Consejos, leg. 51.708).

32 Consulta del Consejo de la Cámara, 14-II-1612 (AHN, Consejos, leg. 51.708). Pelorson expresa sobre los Benavides: «le $\mathrm{L}^{\circ}$. Álvaro de Benavides, asistente de Cortes en 1607 et en 1611-1612 membre du Conseil des Ordres, est frère du sixième Comte de Santiesteban, Don Diego de Benavides y de la Cueva, dont un fils naturel, le $L^{\circ}$. Don Mendo de Benavides, est lui-même fiscal du Conseil des Ordres jusqu'en 1612» (PELORSON, Les Letrados, 216). Destacar que Alvaro de Benavides, en contra de Pelorson, sería consejero de órdenes a partir de 1599 (véase al final su apunte biográfico).

33 Consulta del Consejo de la Cámara, 8-VIII-1613 (AHN, Consejos, leg. 51.708). 
buenas partes». En la resolución también decía el rey «nombreseme personas para lo que deja» Venegas.

$\mathrm{Al}$ año siguiente volverá la Cámara a proponer candidatos para una vacante del Consejo de Órdenes al ascender Álvaro de Benavides a consejero de casti$\mathrm{lla}^{34}$. Cuando esta consulta se envía al rey todavía está pendiente de resolver la del año anterior ${ }^{35}$. Esta vez Felipe III se decantó por el quinto candidato: «para esta plaça nombro a don Garçía de Medrano, fiscal del mismo Cons ${ }^{\circ}$. de Hórdenes, $\mathrm{n}^{\circ} 5$ y nonbrenseme personas para lo que ha de dejar». Medrano acababa de ser procurador de Cortes por Soria «con demostraçión, y es pers ${ }^{\mathrm{a}}$. de buenas partes», según la Cámara.

Para dos plazas vacantes en el Consejo de órdenes, por acceso al Consejo Real de Juan Alderete y de García de Medrano, proponía la Cámara el 31 de marzo de 1604 a dos oidores de la Chancillería de Valladolid ( Ruy Díez de Mendoza y Jerónimo de Medinilla) y a otro de Granada (Luis de Padilla). Cuando el monarca decidió resolver la consulta, probablemente en agosto, se habían producido otras dos vacantes en el Consejo de Órdenes, una de ellas por fallecimiento de Gaspar Bonifaz y de la otra desconozco el motivo. Por ello proveyó cuatro: «Estas plaças - escribió Felipe III-an de ser cuatro y para ellas apruevo a los tres que vienen propuestos y añado para la cuarta a don $\mathrm{D}^{\circ}$. de Salçedo nombrado en otra cons ${ }^{\text {ta }}$. de la fecha desta».

El fallecimiento de los consejeros Venegas y Mendoza obligará a la Cámara a proponer nuevamente el 20 de junio de 1605 - en una única consultacandidatos para las respectivas vacantes ${ }^{36}$. Para la plaza de Venegas los preferidos de la Cámara fueron:

1.- Pedro de Vega, oidor de la Chancillería de Valladolid «que reside en Burgos». Había sido colegial del colegio de San Bartolomé en Salamanca. Eran sus «deudos» los presidentes del Consejo Real y de Indias Juan de Vega y Hernando de Vega, así como el obispo de Sigüenza, Pedro Gasca.

2.- Alonso de Cabrera, también oidor de la Chancillería de Valladolid. Colegial del colegio del arzobispo en Salamanca. Era sobrino de Jerónimo del Corral, que había desempeñado la presidencia de aquélla Chancillería.

3.- Fernando Ramírez Fariña, oidor de la Chancillería de Granada. Había sido juez de grados de la Audiencia de Sevilla y procurador de Cortes por Salamanca. Natural de Toro, tenía —opinaba la Cámara-»buen entendimiento».

\footnotetext{
${ }^{34}$ Madrid, 25-I-1600 (AHN, Consejos, leg. 51.708).

35 Por que en la nueva figura propuesto Egas Venegas.

36 Valladolid, 20-VI-1605.
} 
En cuanto a la otra vacante las propuestas eran:

1.- Sebastián de Villafañe, oidor de la Chancillería de Granada, colegial de Santa Cruz de Valladolid y catedrático de Sexto en su Universidad. Su padre, el doctor Villafañe, formó parte de la plantilla del Consejo y de la Cámara. «Es buen letrado — decía la Cámara de Villafañe - y persona de buenas partes».

2.- Ochoa de Urquizu, oidor de la Chancillería de Valladolid; colegial del colegio de Cuenca en Salamanca; abogado nombrado por el ayuntamiento de Salamanca, el claustro pleno de los doctores de la Universidad de Salamanca le designó para una cátedra de Código. Inició su carrera judicial desempeñando una plaza de alcalde mayor de la Audiencia de Galicia.

3.- Juan de Escobar Chaves y Mendoza, también oidor de la Chancillería granadina, donde ocupó con anterioridad una alcaldía de hijosdalgo. Colegial del colegio de Oviedo en Salamanca, en cuya Universidad sustituyó en cátedras de Leyes y Cánones. Conceptuado por la Cámara como «letrado cuerdo y virtuoso", era sobrino de fray Diego de Chaves, que había sido confesor de Felipe II.

Felipe III designó para una plaza a Pedro de Vega y dijo que la otra ya se había concedido, además resolvió adjudicar la vacante que dejaría Vega:

«La una destas plaças se dio a don Enrique Pimentel, y para la otra nombro a don $\mathrm{P}^{\mathrm{o}}$. de Vega, y para la suya a don Jerónimo de Camargo, y la que el ha de dejar de Granada, a don $\mathrm{R}^{\circ}$. de Vera, y para la de Galiçia que ha de dejarse, me propongan personas».

Curioso. La Cámara no se ha enterado de que ha sido nombrado Pimentel consejero de órdenes. Obviamente la designación de Enrique Pimentel no ha sido precedida de consulta de la Cámara. La propia Cámara, tres meses antes - el 29 de marzo - ha despachado el título de nombramiento de Pimentel, en el cual se expresa que ocupará la plaza vacante por fallecimiento de Ruy Díaz de Mendoza. ¿Cómo se ha producido este nombramiento?. Es un asunto harto complejo. Se me ocurre la posibilidad de una orden verbal o de un billete dirigido por el duque de Lerma al presidente de Castilla, su consuegro el conde de Miranda, comunicando el nombramiento y que éste lo olvidó.

Habrá que esperar cuatro años hasta que sea designado otro consejero de Órdenes: Juan Serrano Zapata. De los trámites de nombramiento del mismo, se conserva un documento que dic: $« \mathrm{D}^{\mathrm{n}}$. Juan Serrano, en consulta de Plaza de Granada del año de 1609». Frecuentemente Felipe III nombraba cuando resolvía consultas de la Cámara, aunque en ocasiones aprovechaba las mismas para conceder otras plazas, como es el caso que nos ocupa. El título de nombra- 
miento de Serrano se despachó el 22 de agosto de 1609 y sucedía a Luis de Padilla, promovido a consejero real ${ }^{37}$.

Dos veces se reunió el Consejo de la Cámara en 1612 para elaborar ternas para plazas de consejero de órdenes. La primera vez fue cuando vacó una plaza del Consejo de Órdenes por ascenso de Medinilla al Consejo Real. En la consulta, de 14 de febrero, figuraba en primer lugar el fiscal del propio Consejo, Mendo de Benavides, que previamente a su paso por el Consejo había desempeñado una magistratura de lo civil de la Chancillería de Valladolid. Su padre, el conde de Santisteban, y «todos sus passados an servido mucho a la Corona real»; era sobrino de Álvaro de Benavides, consejero de castilla y camarista. Alonso de Cabrera, oidor de la Chancillería de Valladolid, iba propuesto a continuación. Cabrera, como se apuntó más arriba, había sido colegial en el colegio del arzobispo de Salamanca y era sobrino de Jerónimo del Corral, que ocupó la presidencia de la Chancillería de Valladolid. El último era Juan Gaitán de Ayala, también oidor de la misma Chancillería. Colegial en el colegio del arzobispo de Salamanca, su padre fue mayordomo del archiduque Alberto; además, un tío suyo, Antonio de Padilla, desempeñó las presidencias de los Consejos de Órdenes y de Indias, y otro, Diego López de Ayala, perteneció a los Consejos de Castilla, de Hacienda y de la Cámara. También Luis de Padilla, consejero de Castilla y camarista, era primo hermano de Juan Gaitán de Ayala.

El rey se conformó con el pretendiente propuesto en primer lugar por la Cámara, al que nombró consejero de Órdenes y su plaza fue concedida al situado en segundo lugar en la consulta ${ }^{38}$.

La otra consulta se realizó el 20 de septiembre de aquél año cuando vacó una plaza de órdenes al ser promovido al Consejo Real Diego López de Salcedo. Los candidatos seleccionados por la Cámara eran Alonso de Cabrera, que apenas hacía cuatro meses que había tomado posesión de la fiscalía de órdenes ${ }^{39}$, Juan Gaitán de Ayala, al que he aludido antes, y Gaspar de Vallejo, oidor de la Chancillería de Granada y con anterioridad juez de grados de la Audiencia de Sevilla. Vallejo había sido colegial de San Bartolomé en Salamanca y catedrático de Cánones en su Universidad. El rey eligió a Alonso de Cabrera, propuesto en primer lugar.

Dos nuevas consultas habrá el siguiente año. Ambas se elaboran el mismo día, 8 de agosto, y en ellas se proponen candidatos respectivamente para dos

37 AGS, QC, leg. 29, fols. 754-762.

${ }^{38} \mathrm{La}$ resolución regia fue: «Nombro para esta plaza al lic ${ }^{\text {do }}$. don Mendo de Benavides $\mathrm{n}^{\circ}$. $1, \mathrm{y}$ para su plaza de fiscal al liç ${ }^{\text {do }}$. don $\mathrm{Al}^{\circ}$. de Cabrera $\mathrm{n}^{\circ}$. 2 y para esta plaza que ha de dejarse, me propongan personas» (Rúbrica real). AHN, Consejos, leg. 51708 . El día 26 de agosto de 1617 el rey otorgaría a Benavides una plaza de consejero de la suprema (GASCÓN DE TORQUEMADA, G.: Gaçeta y nuevas de la Corte de España desde el año 1600 en adelante. Continuada por su hijo DON GERÓNIMO GASCÓN DE TIEDRA, Gentilhombre del Duque de Alburquerque. La publica AlFonso DE CEBAllos-ESCALERA y GILA, MARQués De LA Floresta, Real Academia Matritense de Heráldica y Genealogía, Madrid, 1991, 43).

${ }^{39}$ Lo hizo el 27 de mayo de ese año. AGS, QC, leg. 5, fols. 872-883.

Hispania, LXIII/2, núm. 214 (2003) 657-744 
plazas vacantes en el Consejo de Órdenes. La primera de ellas se ha producido por la promoción de Enrique Pimentel a consejero de la suprema. Los tres magistrados incluidos por la Cámara en su consulta serán:

1.- Juan Coello de Contreras, alcalde de la Casa y Corte, con anterioridad había ocupado una plaza de oidor de la Chancillería de Valladolid. Procurador de Cortes por Salamanca y diputado de la Comisión de Millones. Estuvo siete años en el colegio de San Bartolomé de Salamanca, siendo provisor de Pamplona y de Burgos cuando el cardenal Zapata era prelado de esas diocésis. La Cámara expresaba que Coello «no tiene inclinación de Alcalde y será buen juez en este Consejo».

2.- Pedro de Guzmán, oidor de la Chancillería de Valladolid y antes de la de Granada. Colegial del arzobispo de Salamanca y rector de la Universidad de ella. Su padre era el marqués de Camarasa.

3.- Pedro de Álava, fiscal del Consejo de Órdenes desde comienzos de año y antes oidor de la Chancillería de Valladolid. Colegial del colegio de Santa Cruz de Valladolid y «en la Universidad - manifestaba la consulta- della fue Retor (y juez del estudio y tuvo las cáthedras de Código y Digesto Viejo) y la sostitución de Prima de Leyes y la de Decreto y leyó siete años en propiedad (y en Oñate donde también fue colegial leyó seis)». Desempeñó interinamente el oficio de juez mayor de Vizcaya durante 15 meses y una alcaldía de hijosdalgo. Un bisabuelo suyo, el licenciado Aguirre, perteneció al Consejo Real y su tío Andrés de Álava a la suprema.

Felipe III, como había hecho en otras consultas, prefería promocionar a los fiscales del Consejo de Órdenes, antes que a otros candidatos, por ello nombró al actual fiscal de éste último, Pedro de Álava, propuesto en tercer lugar.

En la otra consulta del mismo día, la Cámara propuso, para la plaza del Consejo de Órdenes que quedó vacante por promoción de Pedro de Vega a la presidencia de la Chancillería de Valladolid, a las tres personas siguientes:

1.- Juan Gaitán de Ayala, oidor de la Chancillería de Valladolid.

2.- Sebastián de Villafañe, oidor más antiguo de la Chancillería de Valladolid «donde sirve desde agosto de 609 , con la antigüedad que tenía en Granada, donde era oydor desde hebrero de 602 , y el mudarle a Valladolid fue por convenir que viniese a presidir en una Sala de aquella Audiençia».

3.- Doctor Mandojana, también oidor de la Chancillería de Valladolid. Colegial de Osma y catedrático de Vísperas de su Universidad. Alcalde mayor de la cuadra de Sevilla; corregidor de Bayona, de Guipúzcoa y de Vizcaya.

El rey designó a Juan Gaitán de Ayala, que era el que menos tiempo llevaba desempeñando una plaza de magistrado de lo civil en la Chancillería de Valladolid, pero propuesto en primer lugar. 
El 17 de junio de 1614 la Cámara propondrá para cubrir la vacante producida por fallecimiento de Pedro de Álava a los tres jueces siguientes:

1.- Juan Coello de Contreras, alcalde de Casa y Corte.

2.- Juan de Chaves y Mendoza, oidor de la Chancillería de Granada.

3.- Luis de Villavicencio, oidor de la Chancillería de Valladolid. Fue colegial del colegio de Cuenca en Salamanca, llegando a desempeñar la cătedra de Volumen en la Universidad de esta ciudad. Villavicencio era natural de Jerez de la Frontera y «deudos suyos - expresa la consulta - an servido en ocasiones de guerra y un hermano suyo murió en ella. Es persona noble, de buenas partes y letras».

El día siguiente, el valido duque de Lerma envía un billete al presidente del Consejo, instando a que la Cámara proponga a Chaves para la vacante de Álava. Por indicación expresa de Lerma, Juan Jiménez de Ocón, fiscal del Consejo de Órdenes, queda preterido en esta ocasión, aunque deberá tenerse en cuenta en el futuro. El billete en cuestión decía:

«Su Magd. manda que para la plaça del Consejo de Órdenes que a vacado por Don Pedro de Álava, se le proponga la persona de don Juan de Chaves, oydor de Granada y no se haze mençión ahora del fiscal del dicho Consejo por algunas consideraçiones. Pero manda Su Magd. que la Cam ${ }^{\text {ra }}$. tenga quenta de consultarle en la primera ocasión que se ofrezca. Guarde Dios a V.S.I. En Palaçio 18 de junio de 1614. El Duq ${ }^{\mathrm{e}}$. (Rubricado). (Alpie) S S. Press $^{\mathrm{te}}$. del Cons ${ }^{\mathrm{o}}$. «40.

Es la primera vez que el duque de Lerma escribe oficialmente al presidente del Consejo de Castilla recomendando a alguien para una plaza de consejero de Órdenes. El presidente, que debía su ascenso a Lerma, era Juan de Acuña ${ }^{41}$. Todas las "grâces passaient par ses mains (del valido)» ${ }^{42}$. Como señala Céspedes, «el cardenal (Lerma) con su privança avía abogádose de tal manera los negocios, que tribunales y Consejos no resolvían ni ordenavan sin su advertencia y voluntad» ${ }^{43}$. También es cierto, como indica Stradling, que entre "1613 y 1614, el rey comenzó a hacer caso omiso de las recomendaciones de Lerma respecto a la asignación de cargos» ${ }^{44}$.

El rey resolverá un mes más tarde, otorgando la plaza a Coello y ascendiendo a Chaves a la alcaldía que éste libere:

${ }^{40} \mathrm{AHN}$, Consejos, leg. 51.708 .

${ }^{41}$ GonZÁlez Dávila, Teatro de las Grandezas, 391-392.

42 ROTT, E.: Pbilippe III el le duc de Lerme (1598-1621). Étude bistorique d'apres des documents inédits, Paris, 1897. Extrait de la Revue d'Histoire diplomatique. La cita en pág. 17. A pesar de tener algo más de un siglo este trabajo, sigue siendo útil.

${ }_{43}$ Céspedes y Meneses, G.: Historia de Don Felipe IIII, Rey de las Españas, Barcelona, 1634, 12.

${ }^{44}$ STradling, R. A.: Felipe IV y el Gobierno de España (1621-1665), Madrid, 1989, 29. 
«Nombro para esta plaça al Liç ${ }^{\mathrm{do}}$. don Juan Coello $\mathrm{n}^{\circ}$. primero y para la plaza de Alcalde de Corte que vacará por él al liç ${ }^{\mathrm{do}}$. don Juan de Chaves y Mendoza».

Algunos historiadores han puesto de manifiesto la relación de Lerma con algunos Consejos de la monarquía, a los que mandaba en nombre del rey, llegando, en ocasiones, a responder a sus consultas. Schäfer y Reglá se refirieron respectivamente a la dinámica del trabajo de Lerma con los Consejos de Indias y de Aragón ${ }^{45}$. Tomás y Valiente analizó la comunicación de Lerma con los Consejos de Estado y de Hacienda ${ }^{46}$ y, últimamente, Escudero ha incidido asimismo en lo ordenado por el duque al Consejo de Estado ${ }^{47}$.

También se relacionará el valido con la Cámara de Castilla, enviando billetes a su presidente, en los que unas veces comunica el nombramiento real de un consejero de castilla ${ }^{48}$ y otras trata de aspectos relativos a provisiones de plazas. O lo que es lo mismo, el rey designará consejeros sin recabar previa consulta a la Cámara, que verá cercenada la competencia que tenía de proponer candidatos para las vacantes de oficios de justicia. Claro está que los nombramientos que comunica el duque son de «hechuras» suyos: Los billetes, unas veces se redactan directamente por el valido y otras por Rodrigo Calderón, uno de sus hombres de confianza. Eso sí, siempre se realizan en nombre del rey. Calderón obtendrá dos títulos nobiliarios: primeramente, el condado de la Oliva y, más tarde, el marquesado de Siete Iglesias ${ }^{49}$. Durante el proceso incoado

45 SCHÄFER, El Consejo Real y Supremo de las Indias, T. I, 188-189, REGLÁ, J.: «La expulsión de los moriscos y sus consecuencias", en Hispania, 13 (1953), 226.

46 TOMÁS Y VALIENTE, Los validos en la monarquía española del siglo XVII, $2^{\mathrm{a}}$ ed., Madrid, 1990, 73-75. Según Lynch, Lerma «daba con frecuencia órdenes perentorias, en nombre del rey, al presidente del Consejo de Hacienda, disponiendo diversos pagos, entre ellos gastos de carácter militar» (LYNCH, J.: Los Austrias (1598-1700), Historia de España, ed. crítica, T. XI, Barcelona, 1993, 43). También esa relación del duque de Lerma con el presidente del Consejo de Hacienda ha sido abordada por García García, B.: La Pax Hispanica. Política exterior del Duque de Lerma, Leuven University Press, 1996, 205 y ss.

47 ESCUDERO, J.A.: «Los poderes de Lerma», en Homenaje al profesor Alfonso García-Gallo, Editorial Complutense, Madrid, 1996, T. II, V*, 78. Según Rott, «les consultes du Conseil d'État ne seront plus communiquées au roi que pour la forme, et quand celui-ci se résignera parfois à les parcourir, voire même à les annoter, ce sera toujours à la demande de Lerme, désireux de se prévaloir auprès de ses collègues de la sanction du souverain» (Philippe III et le duc de Lerme, 6).

48 También, en alguna ocasión, el duque de Lerma comunica al presidente del Consejo de Castilla la designación de un magistrado de una Audiencia o Chancillería. Así, por ejemplo, el billete de Lerma - escrito por Rodrigo Calderón-, en el que avisaba que el rey había nombrado oidor de la Chancillería de Granada a Pedro de Guzmán, decía: «Su Magestad es servido de azer merzed a Don Pedro de Guzmán, hijo del marqués de Camarassa, de la plaça de Granada que está vaca por no averla azetado el $\mathbf{L i}^{\mathrm{do}}$. San Vicente, teniendo consideración a las partes que le consultó la Cámara de su persona y manda que assí lo ordene y que lo diga en la Cámara. Dios guarde a V.E. en Palazio 9 de avril de 1606 (Rubrica el Duque). (Alpie) Señor Conde de Miranda . En AHN, Consejos, leg. 13.515.

49 GASCÓN DE TORQUEMADA, Gaçeta y nuevas de la Corte de España desde el año 1600 en adelante, 33 y 36; Quevedo VILLEGAS, F. DE: «Grandes anales de quince días», en Obras Completas, estudio 
contra Rodrigo Calderón a finales del reinado de Felipe III, se encontraron cartas suyas dirigidas al presidente del Consejo de Castilla, en las que daba «su pareçer» sobre "personas que pretendía se proveyesen en plaças, assí del, como de la Cámara, y de otros Consejos, Tribunales y audiencias»s0. El presidente del Consejo de Castilla Acevedo se opuso a los candidatos que le recomendaban el valido y Calderón:

«Siempre —escribe en sus memorias- que havía alguna provisión de Plazas y oficios, si no salían por resolución de S.M. los que el Duque y Don Rodrigo querían, y tenían grandes encuentros conmigo; de manera que jamás me hacían el festejo, ni aplauso que a los demás Presidentes» $\$ 1$.

Veamos los casos en que de alguna manera intervino el duque de Lerma en la designación de consejeros de Castilla o en algún trámite de su nombramiento.

La primera vez que ocurre es en 1608. En un billete escrito por Rodrigo Calderón, el duque de Lerma comunica al presidente del Consejo de Castilla que el rey ha nombrado a Molina de Medrano como consejero de Castilla, mandando al propio tiempo que se amorticen las plazas que éste último desempeña:

«Su Magd. por la satisfazión que tiene del lizenciado don Molina de Medrano le nonbra para la plaza del Consejo Real que a vacado por Juan Alderete y me a mandado dezirlo a Vm. para que lo diga en el Consejo y en la Cámara y ordene que se le despache su título para que comienze a servir. Y su magd. es servido que la plaza de Molina de Medrano assí del Consejo de Indias como de la Cámara que se consuma y que no se provea y manda que todo se ordene assí. Dios $g^{e}$. a Vm. En Valladolid, 2 de Agosto de 1608. El duq ${ }^{e} . \gg$ (rubricado) ${ }^{\text {s2 }}$.

Otros dos consejeros de Castilla fueron designados por el rey a comienzos de 1609, sin tener en cuenta la opinión de la Cámara, y en cuyos nombramientos influyó decisivamente el valido: Melchor de Teves y Martín Fernández Portocarrero. De estos nombramientos no existió ninguna orden escrita. El rey había comunicado verbalmente al presidente de Castilla -el patriarca de las Indias - la adjudicación de la plaza a Portocarrero. En cuanto a la plaza de Teves, el presidente de Castilla tenía un papel de Rodrigo Calderón «en que

preliminar, edición y notas de F. Buendía, ed. Aguilar, 1974, T. I, 835; RotT, Pbilippe III et le duc de Lerme, 24 y LYNCH, J.: Los Austrias (1598-1700), Historia de España, ed. Crítica, T. IX, Barcelona, 1993, 41. Escudero ha entendido que el conde de la Oliva es un personaje distinto a Rodrigo Calderón (ESCUDERO, «Los poderes de Lerma», pág. 75, texto y notas 114 y 115).

so Consulta de la Junta de jueces del marqués de Siete Iglesias, Madrid, 28-VII-1619, en OsSORIO, A.: Los hombres de toga en el proceso de D. Rodrigo Calderón, Madrid, 1918, 168-210; la cita en pág. 172.

5i Escagedo Salmon, M.: «Los Acebedos», en Boletín de la Biblioteca Menéndez y Pelayo, 7 (1925), 53. Sobre Fernando de Acevedo, véase PELORSON, Les Letrados, 463-466.

s2 AHN, Estado, leg. 6408.

Hispania, LXIII/2, núm. 214 (2003) 657-744 
decía que el duque (de Lerma) le avía mandado escriviese a su señoría Ilustrísima (el presidente) que publicase la plaça del señor don Melchor (de Teves)» ${ }^{53}$.

Dos meses más tarde, el duque de Lerma vuelve a dirigir al presidente del Consejo de Castilla un billete-escrito por Rodrigo Calderón--en el que comunica que el rey ha designado a Luis de Padilla como consejero de Castilla, ordenando al propio tiempo que la Cámara consulte para la plaza vacante que deje Padilla:

«Su mag ${ }^{\mathrm{d}}$. a sido servido de nonbrar para la plaza del Consejo Real que vaca por don García de Medrano a Don Luis de Padilla, del Consejo de Órdenes y manda que V. I. se lo avise luego y le diga que venga a servir y que el Consejo de Cámara proponga personas para su plaza y se invie la consulta. Dios $g^{\text {e }}$ a V. I. En San Lorenzo, 27 de Abril de 1609. El duq. (rubricado). (En línea tendida y separada: En $\mathrm{M}^{\mathrm{d}} .4$ de mayo 1609) (En otra línea más abajo: Despáchesele el título -rúbrica de

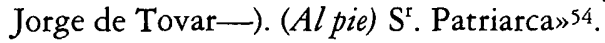

Finalmente, en 1616, cuando ya se ha producido el declive del cardenalduque, éste enviará un billete al presidente de Castilla para que mande al secretario de Justicia de la Cámara que elabore el título del recién nombrado consejero de Castilla Márquez de Gaceta:

«Remitiéndome a lo que su $\mathrm{mg}^{\mathrm{d}}$. escribe a V.m. no tengo que dezir yo aquí mas de suplicar a V.m. hordene al secretario Contreras que haga luego el título que el licdo. Márquez de Gazeta, por que le pueda su $\mathrm{mg}^{\mathrm{d}}$. firmar mañana antes que salga el Consejo y él pueda tomar la posesión. Dios de a V.m. muy buenas Pasquas de Reies y le guarde como deseo. De Palazio a 6 de enero de 1616». El duque (Rúbrica)»s5.

El billete anterior lo escribe personalmente el valido, quien además de rubricar firmará con los títulos de duque y de marqués de Denia. En cuanto a Márquez de Gaceta había sido designado consejero por resolución real a consulta de la Cámara de 5 de octubre de $1615^{56}$.

La última consulta proponiendo la Cámara a Felipe III jueces para consejeros de órdenes es la de 12 de abril de 1616. Elaborará dos ternas para cubrir cada una de las plazas que hay vacantes en el Consejo de Órdenes, una por promoción de Alonso de Cabrera al Consejo Real y la otra también por ascenso de Juan Gaitán de Ayala al Consejo de la Inquisición.

La primera terna era:

1.- Sebastián de Villafañe, oidor de la Chancillería de Valladolid.

\footnotetext{
${ }_{53}$ En Papel de lo que ocurrío (...)». AHN, Estado, leg. 6408

${ }_{54} \mathrm{AHN}$, Estado, leg. 6408.

55 AHN, Estado, leg. 6408

56 AHN, Estado, leg. 6408.
} 
2.- Pedro de Guzmán, también oidor de la misma Chancillería. El que fuera propuesto Guzmán se debió al presidente del Consejo de Castilla. Ello sería así si creemos a Acevedo, arzobispo de Burgos, quien en sus autocomplacientes memorias expresa: ««Don Pedro de Guzmán, consejero de Órdenes, en cuia plaza havía yo consultado de ordenes, tanto por su mucho mérito quanto porque convenía restaurar en parte la quiebra de su padre; y por haver hecho memoria de este cavallero no pudo pasar en blanco, fue persona a quien estimé mucho porque haviéndose havierto el ataúd en que se depositó el cuerpo de mi hermano en San Martín delante de toda Corte le abrazó. Pero después en la propiedad de Felipe quarto no se acordó de mi correspondencia, ni veneficios, ni García Pérez de Arasiel, de los suyos, porque faltaron a la correspondencia devida, y no me espantó porque heran hombres, y sugetos a mudanzas como todos» ${ }^{57}$.

3.- Juan Jiménez de Ocón, fiscal del Consejo de Órdenes. Con anterioridad había desempeñado las plazas de oidor de Comptos, alcalde de la Corte Mayor y consejero de Navarra. En la consulta se recordó que «por billete del Duque de Lerma de 18 de Junio de 614 tiene mandado V. $\mathrm{M}^{\mathrm{d}}$. que la Cámara tenga quenta de consultarle para plaça del dho. Consejo en la primera ocasión que se ofreciese».

En cuanto a la segunda:

1.- Luis de Villavicencio, oidor de la Chancillería de Valladolid.

2.- Antonio de Castro y Andrade, oidor de la misma Chancillería.

3.- Fernando Pizarro de Orellana, oidor de la Chancillería de Granada. Noble, natural de Trujillo, había sido colegial del colegio de Cuenca en Salamanca, ingresó en la carrera judicial desempeñando una plaza de la Audiencia de Sevilla. «Sus pasados sirvieron mucho a la corona real».

Al margen de la consulta, Felipe III dictará dos resoluciones. Una primera en la que nombra a Villafañe y a Jiménez de Ocón para las dos vacantes y además "por que ha de vacar presto en él otra plaça nombro para ella al liç ${ }^{\text {do }}$. don Luis de Villaviçençio, y consulténseme personas para sus resultas destos tres» (Rubricado). En otra, escrita debajo, el rey decidió proveer una vacante que se iba a producir en el Consejo de Órdenes así como la fiscalía del mismo: «nombro para esta plaça que ha de vacar en el Cons ${ }^{\circ}$. de Órdenes por Mandojana al $\mathrm{D}^{\text {or }}$. don $\mathrm{P}^{\circ}$. de Guzmán, y ha de ser supernumeraria asta que se cumplan los dos meses de la jubilaçión de Mandojana; y para la fiscalía deste mesmo Consejo nombro al liç ${ }^{\mathrm{do}}$. don Antonio de Castro, $\mathrm{n}^{\circ} .2^{\circ} . »($ Rubricado).

\footnotetext{
57 Escagedo Salmón, M.: «Los Acebedos», en Boletín de la Biblioteca Menéndez y Pelayo, T. VIII
} (1926), 160. 
Villafañe fallecerá el 10 de mayo, sin haber tomado posesión de su plaza. Jiménez de Ocón pasará a ocupar la vacante de Cabrera ${ }^{58}$, a Villavicencio se adjudicará la plaza que deje Pedrosa al jubilarse ${ }^{59}$ y Guzmán obtendrá la de Gaitán de Ayala ${ }^{60}$.

Una vez designado un consejero - si aceptaba el nuevo destino- acudía a la Cámara, la cual despachaba el título de nombramiento. Con el título en su poder; el flamante consejero se presentaba al Consejo de Órdenes a jurar su cargo ${ }^{61}$. El juramento, por ejemplo, de Luis Padilla realizado cuando se encontraba la Corte en Valladolid fue:

«En la çiudad de Valladolid a quinze días del mes de nobienbre de mill y seisçientos y quatro años. El Sr. Don Luis de Padilla y Meneses, cav $^{\circ}$. de la Orden de Santiago, paresçió ante los señores presidente y demás del $\mathrm{Con}^{\circ}$. de las Órdenes y presentó este título de Su Magd. y por los dhos. $s^{s}$. bisto lo tomaron en sus manos y lo besaron y pusieron sobre sus cabeças y lo obedeçieron con el acatamiento y reberençia debido y mandaron que el dho. don Luis de Padilla aga el juramento que por el se manda, el qual se resçivió en la manera siguiente $=$ Don Luis de Padilla y Meneses, cavallero de la Orden de Santiago, que jura a Dios y al ávito de Santiago que trae en los pechos, que usará bien y fielmente del cargo de consejero que Su $\mathrm{Mag}^{\mathrm{d}}$. le a probeydo, guardando sus mandamientos y Real serviçio, procurando el bien de las Ordenes de Santiago, Calatrava y Alcantara y conserbaçión de sus bulas y libertades, patrimonios y rentas, administrando justiçia con toda rectitud, procurando el bien de las órdenes, sin que aya falta ni negligençia alguna y guardará el secreto lo neçesario y en todo hará lo que debe y es obligado. El qual dixo sí juro, si ansí lo hiziere Dios le ayuda y si no lo demande amén» ${ }^{62}$.

En cuanto al salario percibido por un consejero de Órdenes era desde 1588 de 400.000 maravedís anuales. En efecto, una real cédula de 17 de noviembre de aquél año había incrementado en 100.000 maravedís el sueldo de 300.000 maravedís que hasta entonces percibían los oidores del Consejo de Órdenes ${ }^{63}$. Otra cédula, expedida en Madrid el 19 de noviembre de 1608, dispuso que a cada uno de los cuatro oidores o consejeros se incrementara en 100.000 maravedís su sueldo, con lo que pasaría a ser de $500.000^{64}$.

58 AGS, QC, leg. 17, 471-478.

s9 AGS, QC, leg. 32, 1595-1598.

60 AGS, QC, leg. 37, 322-331.

61 Sobre el título de nombramiento, la recepción del oficial, el derecho al oficio y, en su caso, la revocación del oficio, referido básicamente en el ámbito municipal, véase GARCíA MARÍN, J.M.: La burocracia castellana bajo los Austrias, Madrid, 1986, 227-247.

${ }^{62}$ AGS, QC, leg. 32, fols. 1202 vto. $-1203 \mathrm{r}^{\circ}$.

${ }^{63}$ AGS, QC, leg. 6, fol. $880 \mathrm{r}^{\circ}$.

${ }^{64}$ AGS, QC, legs. 13 y 14, fol. 718. Confróntese lo anterior con lo que expone Postigo de que a finales del siglo XVI «los consejeros de Castilla vieron acrecentados sus ingresos mientras que los de Ordenes continuaron percibiendo los 400.000 maravedís fijados años atrás. De nada sirvieron las numerosas quejas de este organismo para que se acrecentaran los salarios de sus miembros y hubo

Hispania, LXIII/2, núm. 214 (2003) 657-744 


\section{CONSEJEROS DE ÓRDENES DEL REINADO DE FELIPE IV.}

En Grandes anales de quince días comienza Quevedo relatando la muerte de Felipe III:

A 21 de marzo de este año de 1621, a las nueve de la mañana, la majestad del Rey don Felipe III pasó a mejor vida, que en los justos y santos tiene más corteses y más consolados nombres de muerte.

Ninguna cosa despierta tanto el bullicio del pueblo como la novedad viose en este día que en mudar el señor regocijó el reino, sin saber del que sucedía más de que era otro (...) Salió para el Escurial el cuerpo del grande y piadoso rey, no bien acompañado de luces y mal asistido de criados: fue mortificación de su grandeza y amenaza de la de su heredero, pues le mostró cuán seca es la muerte de los monarcas y cuán deslucida y desamparada su memoria65.

Comparto la tesis de Alcalá-Zamora de que el nuevo rey, Felipe IV, participará y decidirá en los asuntos de gobierno ${ }^{66}$. Se empieza a superar esa imagen estereotipada que han transmitido muchos historiadores de que había sido un monarca indolente ${ }^{67}$. Stradling ha señalado que este monarca «a menudo mantuvo una postura crítica hacia la política y el comportamiento de su valido» ${ }^{68}$. Este historiador hispanista también ha dicho que muchas de las resoluciones reales a consultas de los Consejos, por su «estilo y tono denotan claramente que le fueron dictadas al rey por su mentor»; empero, a partir de 1626, parece que las respuestas reales ya no sean opiniones del conde-duque de Olivares ${ }^{69}$. El propio monarca, en la autosemblanza que incorporó a la Historia de Italia de Guicciardini, expresa que a los seis años de su reinado despachaba directamente, «sin secretario que me las leyese», todas las consultas relativas a asuntos de gobierno y a propuestas de oficios ${ }^{70}$. Según el conde de la Roca, amigo y admirador del conde-duque de Olivares, éste desde las 9 a las 11 de la mañana se

que esperar hasta 1600, en que el Capítulo General de la Orden de Santiago, reunido en Madrid hizo una petición formal al rey para que aumentara los 100.000 maravedís que permitían igualar los sueldos de los consejeros de ambas instituciones» (POSTIGO CASTELlanos, Honor y privilegio en la Corona de Castilla, 94).

65 "Grandes anales de quince días", 817-818; Jauralde POU, P.: Francisco de Quevedo (15801645), Madrid, 1998, 430-431.

66 AlCalÁ-Zamora y Queipo de Llano, J.: España, Flandes y el Mar del Nórte (1618-1639): La última ofensiva europea de los Austrias madrileños, Barcelona, 1975, 31.

67 Hace ahora treinta años el hispanista Devèze decía del cuarto Felipe que era de «nature indolente, sans caractère et sans volonté, mais sensuel et délicat, se sentait mal à làise dans son rôle de roi, qui demandait energie, tenacité, volonté» [DEVÊZE, M.: L' Espagne de Pbilippe IV (1621-1665), Paris, 1970, T. I, 86].

68 STRADLING, Felipe IV y el Gobierno de España, 67.

69 STRADLING, Felipe IV y el Gobierno de España, 98.

70 «Autosemblanza de Felipe IV», en SeCo SerRano, C.: Epistolario español. V. Cartas de Sor Maria de Jesús de Ágreda y de Felipe IV, T. CIX, Madrid, 1958, 233.

Hispania, LXIII/2, núm. 214 (2003) 657-744 
encargaba de ajustar "con quatro Secretarios las consultas que ha de ver, y resolver el Rey para volverlas a los Consejos» ${ }^{71}$. El mismo conde de la Roca manifiesta que el valido apenas participaba en las consultas de provisiones eclesiásticas, aspecto reservado al confesor real; como «los Consejos - explicaba el conde-enviaban los pliegos al Rey, así se los ponía en el bufete del despacho de S. M. (esto es cierto) y a puerta cerrada los abría, y habiéndolos abierto, y reconocido, los mandaba cerrar, y llevar al Confesor, el qual con la noticia que le dan las consultas Eclesiásticas, y la que tiene de los sugetos en un papel, que encaxa en cada consulta, dice su parecer, y el Rey le sigue tan ordinariamente, que de cien consultas, no habrá dos, que no sean del Confesor; en lo qual nada hace el Conde (de Olivares) $»^{72}$. En la década de los treinta, Felipe IV pasaba muchas horas trabajando en su despacho ${ }^{73}$. Creo que acierta Elliott cuando dice que Olivares ultilizó el patronazgo en menor medida que el duque de Lerma ${ }^{74}$.

El conde-duque sabía mejor que nadie lo importante que era controlar a los que se encargaban de gestionar los nombramientos, porque como ya observara Malvezzi "qué importa que él (valido) elija para todos los oficios, basta para elegir que haya elegido a aquellos que eligen, porque entonces es seguro que será elegido aquél que él hubiera elegido» ${ }^{75}$. De esta manera, en la década de los veinte y de los treinta el valido situará en el Consejo de la Cámara —cuyos miembros se designaban directamente por el rey, sin consulta previa de ningún órgano colegiado - a sus más fieles colaboradores ${ }^{76} \mathrm{o}$ a otros letrados que, como dice Elliott, habían despertado su interés77: Alonso de Cabrera, Juan de Chaves y Mendoza ${ }^{78}$, Fernando Ramírez Fariña ${ }^{79}$, García Pérez de Araciel ${ }^{80}$, García de Haro y Avellaneda ${ }^{81}$, Francisco de Tejada y Mendoza ${ }^{82}$, Diego de Corral y Are-

71 Vera y Figueroa, J. A. DE, CONDE DE la RoCA: «Fragmentos históricos de la vida de D. Gaspar de Guzmán», en Semanario Erudito, t. II, 245.

72 Vera y FigueroA, «Fragmentos históricos de la vida de D. Gaspar de Guzmán», 292.

${ }^{73}$ Elliott, J.: «Conservar el poder: el Conde-Duque de Olivares», en El mundo de los validos, bajo la dirección de J. Elliott y L. Brockliss, Madrid, 1999, 170.

${ }^{74}$ «Mucho más moderada y selectivamente», como expresa Elliott («Conservar el poder: el Conde-Duque de Olivares», 173).

75 MALVEZZI, V.: Il ritratto del privato politico christiano estratto dall'originale di alcune ationi del conte-duca di Olivares, Bolonia, 1635, 99; cit. BENIGNO, La sombra del rey 149-150.

76 BENIGNO, La sombra del rey, 156.

77 El conde-duque de Olivares, 302.

78 Ambos nombrados por decreto expedido en Madrid el 31-VII-1621 (AHN, Estado, leg. $6404^{2}$, doc. 8).

79 Decreto, Madrid, 7-XII-1622, en AHN, Estado, leg. 6404², doc. 9.

80 Decreto, El Pardo, 6-II-1624, en AHN, Estado, leg. 6404², doc. 10.

81. Decreto, Madrid, 31-III-1625, en AHN, Estado, leg. 6404², doc. 11. García de Haro, conde de Castrillo, al amparo del valido desarrollará una carrera fulgurante: designado a finales del reinado de Felipe III oidor de la Chancillería vallisoletana, en 1623 asciende al Consejo de Órdenes y, un año después, al Consejo de Castilla (FAYARD, Los ministros del Consejo Real de Castilla, 11-12).

82 Decreto, Madrid, 5-X-1629, en AHN, Estado, leg. 6404², doc. 12. 
llano ${ }^{83}$, Juan Chumacero y Carrillo ${ }^{84}$, José González ${ }^{85}$, Francisco Antonio de Alarcón $^{86}$, Antonio de Contreras ${ }^{87}$ y Antonio de Camporredondo ${ }^{88}$. Todos ellos, sin excepción, formarán parte de las diversas Juntas que se creen durante el valimiento de Olivares. En la Junta de Reformación estarán Cabrera, Chaves y Garcipérez; García de Haro en la de Población; Alarcón y González en la de Minas; Tejada en la de Compañías; Juan Chumacero en la Junta Grande; Fariña en la de la Sal; Corral en la de Colegios; Contreras y Camporredondo en la de Millones ${ }^{89}$.

\section{A) Nombramientos previa consulta de la Cámara. Votos secretos}

Cuando el monarca tenía noticia de cualquier vacante en el Consejo de Ordenes, solicitaba a la Cámara, mediante orden dirigida al presidente o gobernador del Consejo, que propusiera sujetos para ella ${ }^{90}$.

83 Decreto, Madrid, 6-XI-1629, en AHN, Estado, leg. 6404², doc. 13.

${ }^{84}$ Decreto, Madrid, 13-III-1631, en AHN, Estado, leg. 6404 ${ }^{2}$, doc. 14.

85 Decreto, Villatovas, 13-IV-1632, en AHN, Estado, leg. 6404², doc. 15.González antes de desempeñar una plaza de asiento de magistrado había sido abogado y como tal ayudó al condeduque a conseguir el territorio ducal de San Lúcar la Mayor (ElliotT; El conde-duque de Olivares, 302). Éste «hidalgüelo riojano que nunca pudo llegar a título, ni siquiera alcanzar el don (...) fue uno de los hombres con más influencia y más poder efectivo" (DOMínguEz ORTíz, A.: Política y Hacienda de Felipe IV, Madrid, 1960, 173). Al igual que el conde de Castrillo, este hombre de confianza de Olivares, tuvo una carrera meteórica: fiscal de la Chancillería de Valladolid (1624); fiscal de la Sala de Casa y Corte (1626); fiscal del Consejo de Castilla (1628); consejero de Castilla (1629). FAYARD, J.: «José González (1583?-1668), «créature» du comte-duc d'Olivares et conseiller de Philippe IV», en Hommage a Roland Mousnier, Paris, 1981, 351-368.

86 Decreto, Madrid, 11-IX-1634, en AHN, Estado, leg. 6404², doc. 16.

87 Designado en 1638, no se conserva en el AHN, Estado, leg. $6404^{2}$ su decreto de nombramiento.

${ }^{88}$ Decreto, Madrid, 10-III-1639, en AHN, Estado, leg. 6404², doc. 17.

89 Véanse Domínguez Ortiz, Política y Hacienda de Felipe IV y Baltar Rodríguez, Las Juntas de Gobierno en la Monarquía Hispánica.

90 Recojo tres peticiones de consulta:

1.- «Con la promoçión de don Gaspar de Bracam ${ }^{\text {te }}$. al Cons ${ }^{\circ}$. y averse de yr aora a Ytalia Don $A n t^{\circ}$. Ronquillo, queda el Cons ${ }^{\circ}$. de las Órdenes sin consexero de la orden de Alcántara, que conforme a difiniçiones deve averle y así me propondrá el Con ${ }^{\circ}$. de la Cámara sujetos prover una plaça en dho. Cons ${ }^{\circ}$. de Órdenes» (Madrid, 7-III-1635. Al Arzobispo de Granada).

2.- «La experiençia ha mostrado quanto conviene que los Ministros, que exerçen el puesto de Alcalde de mi Cassa y Corte, sean de edad, y'salud, que puedan acudir a las obligaçiones del con la actividad, y continuación que neçessita y pide el buen Gobierno de la administra $^{\circ}$. de la Justiçia, que por su exerçicio les incumbe, y así he tenido por conveniente advertirlo al Conss ${ }^{\circ}$. de la Cámara para que se esté con esta atención en lo de adelante, y que se propongan luego personas para la plaza del Conss ${ }^{\circ}$. de Órdenes, que ha vacado por muerte de Don Marcos Tamariz de la Escalera, sin embargo de ser supernumeraria» (Madrid, 9-IX-1650).

3.- «He resuelto que se provea una Plaza en el Conss ${ }^{\circ}$. de las Órdenes y así se me propondrán luego sujetos para ella por la $\mathrm{Cam}^{\mathrm{a}}$. para que yo elija el que tuviere por conveniente, res- 
Felipe IV escribirá de su puño y letra todas las resoluciones hasta aproximadamente 1660 . Desde esa fecha sus resoluciones son escritas por otro, probablemente el Secretario del Despacho Universal. Eso sí, aquél continúa rubricando sus respuestas, respuestas que siempre decide. En 1647 el rey escribía a sor María de Ágreda que, aunque se asesoraba de «ministros» para resolver las consultas, él era quien decidía:

«Yo, Sor. María, no rehuso trabajo alguno, pues, como todos pueden decir, estoy continuamente sentado en esta silla con los papeles y la pluma en la mano, viendo y pasando por ella todas cuantas consultas se me hacen en esta Corte y los despachos que vienen de fuera, resolviendo las más materias allí inmediatamente, procurando se ajuste el dictamen que tengo por más ajustado a la razón; otros negocios de mayor peso y que piden más inspección para resolverlos, remito a diferentes ministros para, habiéndolos oído, resolver lo que tengo por más conveniente. En fin, las ültimas resoluciones no pasan por otra censura, pues es esto lo que yo entiendo que a mí me toca» ${ }^{91}$.

Los membretes de las consultas de la Cámara para la provisión de oficios de justicia serán algo distintos en tiempos de Felipe IV que en los de su antecesor. En la época de Felipe III figura en aquéllos la fecha de la consulta, un resumen de la misma y, en algunos casos, se incluye la resolución real, con su rúbrica correspondiente. Por el contrario, los membretes de la Cámara del cuarto Felipe, además de esos elementos, añaden las señales del consejero o camarista más moderno y del secretario de Justicia.

A comienzos de su reinado, Felipe IV ordenó que cuando respondiera a las consultas de los Consejos, los secretarios de éstos remitieran los membretes de ellas al secretario del Despacho, "pues conviene» conocer «lo que se me consulta y yo resuelvo»92. Algunos Consejos no cumplieron esta disposición. Por ello, en 1638, el mismo rey resolvió que se enviara con la consulta dos membretes, ambos rubricados por un consejero y el secretario, uno de los cuales quedaría archivado en la secretaría del Despacho ${ }^{93}$.

pecto de tener enten ${ }^{\text {do }}$. se necessita de más juezes en dho. Consejo por los neg ${ }^{\text {os }}$. que en el se ofrezen» (Buen Retiro, 31-V-1656).

${ }^{1}$ Seco Serrano, C.: Epistolario español. IV. Cartas de Sor María de Jesús de Ágreda y de Felipe IV, BAE, T. CVIII, Madrid, 1958, 92. La cursiva es mía.

92 En orden de 25-II-1638 (TOMÁs Y VALIENTE, Los validos en la monarquía española del siglo XVII, 187).

93 «Reduciendo - expresaba la orden citada en la nota anterior - los membretes de las Consultas a sola una breve noticia de lo que contienen, vengan señaladas de un consegero; y del Secretario a quien tocare, otro membrete de por sí juntamente con la Consulta que a de quedar en mi Secretaría del Despacho, que reduzca en substancia más extensamente lo que se me consultare»; de la no ejecución de lo anterior responderían el secretario y consejero que hubieren rubricado el membrete. Esta orden debió comunicarse a todos los Consejos. Para el Consejo de Aragón, véase ARRIETA AlBerdi, J.: El Consejo Supremo de la Corona de Aragón (1494-1707), Zaragoza, 1994, 468-469.

Hispaniá, LXIII/2, núm. 214 (2003) 657-744 
¿Cuánto tiempo tardaba el rey en resolver las consultas? No mucho. Por ejemplo, los primeros años de la década de los treinta era bastante expeditivo, resolviendo en unos cuantos días. Así, la consulta de la Cámara de 20 de marzo de 1632 llegó respondida el 16 del mes siguiente; la de 27 de agosto de ese año, tres días más tarde; la de 4 de septiembre, dos días después y la del 19 de enero de 1633, el 24 del mismo.

Un decreto de 28 de febrero de 1643 dispuso que ningún Consejo o Junta propusiera candidatos para plazas, oficios de justicia y empleos militares en que mediara dinero, porque el rey quería que los cargos se concedieran teniendo en cuenta los méritos de los pretendientes ${ }^{94}$.

En las primeras consultas del Consejo de la Cámara del reinado de Felipe IV aparece como pretendiente a una plaza del Consejo de Órdenes Fernando Pizarro de Orellana, noble natural de Trujillo, que alegaba para ser promocionado los servicios de sus antepasados, de su padre Hernando de Orellana, que había estado en la guerra de Granada y de sus abuelos Juan Pizarro de Orellana y Hernando Pizarro que participaron en la conquista del Perú en compañía del marqués Francisco Pizarro, hermano del último.

Recién iniciado su reinado, se volverá al estilo que tenía el Consejo de la Cámara antes de 1602 a la hora de consultar para las vacantes de empleos de justicia. Ahora, si el presidente y los consejeros de la Cámara no están de acuerdo en los candidatos a proponer en cada lugar, entonces elegirá cada uno a tres aspirantes ${ }^{95}$. Habrá consultas en las que figuren 15, 18 y hasta 21 candidatos ${ }^{96}$. Por el contrario, en otras consultas se propondrá a un solo candidato para una plaza de consejero ${ }^{97}$, accediendo el rey a su nombramiento.

Por orden de 3 de noviembre de 1647, Felipe IV cambiará nuevamente el método de las propuestas de la Cámara. Se vuelve al estilo fijado en 1602 en que de los tres pretendientes seleccionados se situará en primer lugar el que más votos obtenga, detrás figurará el segundo más votado y en último lugar irá el menos votado ${ }^{8}$.

\footnotetext{
94 De León Pinelo, A.: Anales de Madrid (desde el año 447 al de 1658), transcripción, notas y ordenación cronológica de Pedro Fernández Martín, Madrid, 1971, 326.

95 Véase en el anexo final las consultas de 17-XII-1622, 27-II-1624, 25-VIII-1631, 20-III1632, 4-IX-1632 y 19-I-1633.

96 Como las de 25-VIII-1631 y de 20-III-1632.

97 Véase en el anexo final las consultas de 8-X-1642 y de 9-VI-1649.

98 En consulta del presidente del Consejo de Castilla de 17-XI-1647. En esta consulta el presidente solicitaba aclaraciones de la norma:

«(...) Así entiendo lo que V.M. manda en esta orden: que se prefieran en las consultas y lugares de ellas, las personas que igualados todos los votos que se hallaren en la Cámara vinieren a tener mayor número en cualquiera grado que sea; que es decir que el mayor número de votos componga la consulta y los lugares de ella en cualquier grado. Porque decir que el que no tuvo para primero ni segundo lugar voto ninguno sino para el tercero, si en él tuvo cinco votos, se a de preferir a los que tuvieron cuatro en el primero y segundo lugar; sería en mi sentir contra justicia, en perjuicio de los elegidos contra la voluntad de los que consultan, y consiguientemente contra el servicio de V. M.
}

Hispania, LXIII/2, núm. 214 (2003) 657-744 
Cuando se proponga una terna, Felipe IV casi siempre designará al colocado en primer lugar ${ }^{99}$. En dos ocasiones el rey nombrará a alguien que no va en la consulta ${ }^{100}$. Cuando se propongan 15,18 o 21 candidatos el rey se decantará, o bien por uno de ellos, o bien por alguno no propuesto ${ }^{101}$.

En alguna ocasión cuando el monarca fue consultado para alguna plaza, decidió no proveerla. Así, el 17 de octubre de 1651 proponía la Cámara para un empleo vacante por promoción de Villamarín al Consejo de Indias, el rey respondió: "No es necessario proveer esta plaza ahora» ${ }^{102}$. Diez años más tarde el Consejo de la Cámara propuso para una plaza supernumeraria y el rey también se negó a proveerla ${ }^{103}$.

En las votaciones para plazas de asiento cuando algún candidato era pariente de un miembro de la Cámara, éstos votaban en primer lugar y luego se ausentaban de la reunión. Así, en la votación para la vacante que dejó Hierro al

Sería contra justicia, porque los preferidos en grado, respecto del tercero, vendrían a quedar después de él. Sería contra la voluntad de lo que consultaron, porque la inclusión del primero y segundo nombrados ocuparon aquellos lugares, excluyendo de ellos a los demás, y si no revocan su nombramiento no puede haber vacío para el excluido del primero y segundo, se ponga en el primero; ni se puede decir a V.M. que la Cámara propone en primer lugar a aquél de quien no se hizo mención en el primero y segundo, sino en el tercero lugar; y entendiendo V.M. que merece más que los otros, vendría a elegir al menos digno, con perjuicio de los más dignos y contra el voto de la mayor parte (....)

Estas razones tienen en mí tanto peso que, cuando hubiera estilo contrario, se había de servir V.M. de reducirle a esta inteligencia, porque no puede ser jurídico el que quite su lugar a los primeros un voto más en el último, y que este voto lo sea de mayor provecho y prelación votando por él en tercero lugar que si le diera el primero, porque en él como sólo fuera inútil para sacarlo del último lugar (....)». La resolución de Felipe IV a la consulta fue: «Habiendo comunicado los puntos de esta consulta a diferentes Ministros y con Fray Juan Martínez, por lo que me representasteis, y oído su parecer, he resuelto se ejecute lo que últimamente tengo mandado, y así os ordeno se publique el decreto que en esta razón envío, para que en lo de adelante se guarde el estilo antiguo» («Papeles del Consejo y Cámara de Castilla, 1645 a 1647», en Colección de documentos inéditos para la Historia de España, T. XCV, Madrid, 1890, 309-312).

99 En las consultas de 22-VII-1626, 26-IV-1651, 10-VII-1662 y 26-III-1664 el rey nombró al que iba en segundo lugar, y en las 14-IX-1650 y 24-III-1654 al tercero.

100 Consultas de 8-IV-1652 y 24-I-1659.

101 Véase en el anexo las consultas.

102 Los propuestos eran José del Pueyo, Juan de Cerecedo y José Pardo de Figueroa (AHN, Consejos, leg. 51.708.

103 «Aunque-consultaba el 19 de enero de 1661 la Cámara- el número de los del Consexo de las Órdenes es de seis consegeros, y ay probeydos siete con Don Lope de los Ríos, que actualmente se halla sirviendo la Regençia de Navarra y el cargo (en ínterin) de aquel Reyno. Respecto de aver falleçido el liçen ${ }^{\text {do }}$. Don Juan de la Estrada y de los muchos negocios que ocurren en dicho Conss ${ }^{\circ}$. a que es preçiso acudir como combiene al mayor serviçio de V. Mag ${ }^{\mathrm{d}}$. y a la buena administraçión de justiçia. Tiene la Cámara por neçess ${ }^{\circ}$. se provea en él otra plaça más de consegero, como ha avido últimamente. Para la qual propone» los siguientes sujetos: Fernando Queipo de Llano, Juan de Córdova y Juan de Navarrete. La resolución regia indicaba: «supuesto que están cumplidas las Plazas, y que también $D$. Lope de los Ríos vendrá a servir la suya, se escusará el proveer esta que se me propone». AHN, Consejos, leg. 51.708. 
ser promovido a fiscal del Consejo Real, el camarista Antonio de Camporredondo «votó el primero y se salió del Consejo para que se acavase de votar por ser Don Diego Çapata su yerno»104. También cuando la Cámara, el primero de julio de 1665 , propuso sujetos para una plaza supernumeraria, el presidente del Consejo de Castilla, «cumpliendo con las resoluçiones de V. Mag. en materia de los parentescos, así de sangre como de afinidad, por el que tiene su nuera con Don Francisco de Moscoso, hijo del conde de Altamira, que es pretendiente, votó el primero, y se salió fuera y lo mismo hiço Don Juan de Carvajal, por el que tiene con Don Pedro de Ulloa y Golfín» ${ }^{105}$.

En la Cámara se discutía y se votaba públicamente. No obstante, en tres ocasiones se votó reservadamente ${ }^{106}$. Ello ocurrió en los años 1635-1638. La primera vez fue cuando se produjo una vacante en el Consejo de Órdenes al ser designado Antonio Briceño Ronquillo como Gran Chanciller de Milán y el rey mandó que la Cámara propusiera candidatos para su plaza ${ }^{107}$. Nuevamente se propuso por votación secreta cuando se creó una plaza supernumeraria de consejero por encontrarse algunos consejeros ausentes ${ }^{108}$. La última vez que se uti-

\footnotetext{
${ }^{104}$ Consulta de 31-VIII-1648. El rey designó precisamente a Zapata.

105 AHN, Consejos, leg. 51.708.

106 Para el Consejo de Aragón, véase ARrieta, El Consejo Supremo de la Corona de Aragón, 440-441.

${ }_{107}$ De este asunto únicamente se conserva el papel que escribió al rey el secretario de la Cámara, que decía: «El Liçen ${ }^{\text {do }}$. Don Antonio Briceño Ronquillo, del ábito de Alcántara y del Consejo de Órdenes está proveído por Gran Chançiller de Milán y su partida ha de ser muy presto y por que en aquél Consejo es neçesario que aya ministro de la misma orden para los negoçios que se ofrezen della. Y ha mandado V. $\mathrm{mg}^{\mathrm{d}}$. que se le propongan personas para proveher su plaza. La Cam ${ }^{\mathrm{ra}}$. cumpliéndolo las propone en los botos de cada uno de los della que ban con este. Haviendo yo hecho primero relación de los subgetos que pueden ocupar este puesto, cuyas relaçiones van aquí. Que V. $\mathrm{mg}^{\mathrm{d}}$. mandará ver y proveherá lo que fuere servido. En $\mathrm{M}^{\mathrm{d}}$. a 12 de março de 1635» (Rúbrica del secretario). Y también la resolución real escrita en el membrete: «Nonbro a don Juan Girón, fiscal del Cons ${ }^{\circ}$. de Guerra, mudando el ávito que tiene al de Alcántara» (Rúbrica real). Años más tarde cuando el rey nombre a otro consejero de órdenes como Gran Chanciller de Milán conservará la plaza del Consejo: «A Don Diego Zapata — disponía el decreto despachado el 10 de marzo de 1652-, a quien se ha conferido el cargo de Gran Chançeller de Milán, he hecho merced de que se le conserve la plaza del Conss ${ }^{\circ}$. de las Órdenes, y que los gajes y emolum ${ }^{\text {tos }}$. de ella se le paguen en el Estado, en la misma forma y $\operatorname{man}^{\mathrm{a}}$. que se pagava a Don Gerónimo Quijada, su anteçesor, la plaza del Conss ${ }^{\circ}$. de las Indias. Tendráse entendido en la Cámara». En AHN, Consejos; leg. 51.708.

${ }_{108}$ El papel que envió el secretario de la Cámara para que el rey resolviera expresaba: «El arçobispo de Granada, Governador del Consejo, ha referido en la Cámara que por consulta suya a sido V. $\mathrm{mg}^{\mathrm{d}}$. servido de mandar se le propongan subgetos para la provisión de una plaza del Consejo de Órdenes del ávito de Alcántara por no haver en el ninguno que le tenga y haver muchos días que falta don Juan Xirón que le tenía y ser preçiso que le aya conforme a los establecimientos. Y aunque V. $\mathrm{mg}^{\mathrm{d}}$. por una orden suya de 23 de julio de 624 tiene mandado que no se le consulten plazas supernumerarias quando bacaren o añadidas por que todas se han de reduçir al número que havía en tiempo del Rey nuestro Señor don Felipe $2^{\circ}$. su abuelo, por que los que havía entonces eran solamente quatro, si bien los muchos negoçios después acá an obligado a crezer el númº ${ }^{\circ}$ de siete y la Cámara siempre que se a ofrezido ocasión de provisión lo ha representado a V. $\mathrm{mg}^{\mathrm{d}}$. como lo haze agora. Y para que V. $\mathrm{mg}^{\mathrm{d}}$. sepa los que ay en aquél Consejo se referirán sus nombres que son los
} 
lizó el método de votar secretamente fue con motivo de la provisión de la plaza vacante que quedó en el Consejo de Órdenes al ser promovido Zambrana al Consejo Real ${ }^{109}$. En los membretes de las consultas de la Cámara con votos secretos no rubrica el camarista. En 1643 el rey dispuso que en lo sucesivo se votara en las sesiones de los Consejos públicamente ${ }^{110}$.

\title{
B) Nombramiento por decreto
}

La primera vez que el rey designa un consejero de órdenes sin tener en cuenta la opinión de la Cámara es en 1627. Felipe IV nombrará consejero supernumerario del Consejo de Órdenes a Gaspar de Bracamonte, fiscal del mismo. El decreto dirigido al presidente del Consejo de Castilla disponía:

«A Don Gaspar de Bracamonte, fiscal del Cons ${ }^{\circ}$. de las Órdenes he hecho merced de plaza de consejero de aquel $\mathrm{Con}^{\circ}$. con el voto y preeminencias que tie-

\begin{abstract}
liçen ${ }^{\text {dos }}$. don Ant ${ }^{\circ}$. de Luna, don Juan de Mendoça, don Sebastián Çanbrana, don Diego de Çeballos, don Manuel de Guzmán, don Lope de Morales, don Juan Xirón (y el fiscal Valtodano). Y don Manuel de Guzmán está en Flandes y don Juan Xirón en Alemania y don Sebastián Çanbrana pidiendo el donativo. Con que sólo ay en el Conss ${ }^{\circ}$. quatro sin el fiscal. $Y$ en conformidad de lo que agora ha mandado V. $\mathrm{mg}^{\mathrm{d}}$. haviendo yo hecho relaçión de las pers ${ }^{\text {as }}$. que podrían ser propuestas, consultan los de la Cámara, los que V. $\mathrm{m}^{\mathrm{d}}$. berá en el voto de cada uno, que ban con las relaçiones, haviendo adbertido don Juan de Chaves en el Consejo y asegurado que los negoçios de la Horden de Alcántara, no se pueden despachar sin que aya consejero que tenga ávito de la misma orden, que es conforme a los estableçimientos, por que si V. $\mathrm{mg}^{\mathrm{d}}$. fuere servido de elijir persona que tenga avito de Sant ${ }^{\circ}$. aya de ser con obligaçión de mudarle en el de Alcántara. Y también se abló en el Cons ${ }^{\circ}$. que don Diego $\mathrm{R}^{\circ}$. Valtodano, fiscal tiene voto de consejero, y por que podría ser que se ofreziere diferençia entre el y el que agora se nonbrare en raçón de la preçedençia, pareçió al Consejo sería justo que V. mg ${ }^{d}$. se sirviese de darle título de consejero, por quitar con esto la ocasión de la dubda. En $M^{\mathrm{d}}$. a 6 de otubre 1636» (Rúbrica del secretario del Consejo de la Cámara). La resolución real anotada en el membrete dispuso: «Nombro a don Álvaro de Occa con condición que mude el ávito de Santiago en el de Alcántara" (Rúbrica real). Más tarde, la Cámara -en consulta de 15 de octubre de 1636 solicitó al rey que declarase si a Diego Rodríguez Valtodano, fiscal del Consejo de las Órdenes, que tenía ya voto de consejero, se le otorgara título de consejero para evitar diferencias sobre la precedencia entre él y Álvaro de Oca, recién designado consejero. Y el rey resolvería favorablemente: «déssele el título» (Rubrica real). Lo anterior en AHN, Consejos, leg. 51.708.

${ }^{109}$ El documento justificativo que se custodia es el siguiente: «Por la promoción al Consejo del liçen ${ }^{\text {do }}$. don Sebastián Çanbrana de Villalobos, queda vaca la plaça del Consejo de Órdenes que tenía y para ella ha pareçido en la Cámara proponer a V. $\mathrm{mg}^{\mathrm{d}}$. personas. Lo qual hazen los del Consso. con sus votos en la forma que se acostumbra. Haviendo yo hecho primero relaçión de los subgetos que pueden ocupar este puesto, cuyas relaçiones de partes y serviçios ban en este juntam ${ }^{\text {te }}$. con los votos, que siendo V. $\mathrm{mg}^{\mathrm{d}}$. servido podrá mandar ver. En $\mathrm{M}^{\mathrm{d}}$. a 22 de $7^{\mathrm{re}}$. de $1638 \%$. La respuesta real fue: «Nombro a don Claudio Pimentel y para la fiscalía a uno de los dos de las levas de Cartagena y al otro se le de la plaza de Alcalde de Corte, en que me los dividiréis por consulta, y se les avisará que hasta que yo mande otra cosa se han de detener en las cosas destas que yo mandaré» (rúbrica real).

110 Decreto, 2-III-1643 (De León Pinelo, Anales de Madrid, 326).
\end{abstract}


nen los demás que me sirven en él, vos se lo diréis, y que hasta que sea otra mi vo$\operatorname{lun}^{\mathrm{d}}$. ha de acudir a las obligaciones del officio de fiscal que quedan por su quenta, sperando de la atención y zelo con que me sirve, que las tratará con toda asistencia y cuidado. Con esta declaración se le despachará el título de consejero» ${ }^{111}$.

No agradó a la Cámara esta decisión regia, que mermaba claramente sus competencias. Por ello, cuando conoció el decreto - el misma día de su expedición-se reunió y, antes de su publicación, propuso al rey los inconvenientes que se producirían de aplicarse el mismo. El Consejo de la Cámara objetaba que cuando era designado un consejero supernumerario se vulneraban las expectativas de promoción de otros jueces, sobre todo de aquellos que prestaban sus servicios en alguna de las dos Chancillerías; asimismo que cuando un fiscal desempeñaba al propio tiempo una consejería descuidaba su trabajo de la fiscalía y que, en los casos de concesiones hábitos, el fiscal sería juez y parte, planteándose también no pocos conflictos de precedencia cuando concurriera a los actos públicos el fiscal-consejero. Finalizaba la consulta de la Cámara con una critica velada al sistema de provisión de plazas cuando era preterida la Cámara ${ }^{112}$.

111 Madrid, 8-XII-1627 (AHN, Consejos, leg. 51.708).

112 La consulta de la Cámara de 8 de diciembre de 1627 manifestaba: «Este Decreto se vió en la Cámara, haviéndose juntado los que sirven en ella en la Sala de Govierno después de acavado el Consejo, luego que se reçivió para dar quenta del y ejecutar lo que V. Mag ${ }^{d}$. se sirve de mandar por él, pero antes de hacerlo y de publicarlo, cumpliendo con la obligación que se deve al mayor servicio de V. Mag ${ }^{d}$. a parecido necesario y conveniente proponerle las raçones siguientes para que vistas y entendidas por V. Mag ${ }^{d}$. como dueño y señor de todo resuelba lo que más convenga.

La primera que en lo general para la causa pública premio de los que an serbido esperanças para que otros lo hagan como deven asçenso de los ministros inferiores tiene grandes inconvenientes criar plaças supernumerarias como en sustancia lo viene a ser esta, pues llegada la ocasión de haverse de proveer y consultar por la Cámara, queda çerrada la puerta de la esperança del premio a los que con muchos años de estudios y de travajos en ambas Chancillerías tienen merecido que se haga relaçión dellos y memoria a V. Mag . y siendo promovidos dejan lugar para pretender el mismo asçenso los que sirven en plaças de Alcaldes del Crimen, de Hijosdalgo, de fiscales y de las Audiencias de Sevilla y Galiçia y aunque la persona de Don Gaspar de Bracamonte sea de tan buenas partes su acrecentamiento es particular y lo público se deve preferir y reparar en ello tanto mas que en todos los Consejos se an proveido muchas plaças por este camino y V. Mag ${ }^{d}$. tiene mandado sintiendo estos inconvenientes y otros que las plaças supernumerarias se vayan consumiendo como fueren vacando.

La segunda raçón de reparo consiste en que si bien V. Mag ${ }^{d}$. por sus partes y servicios querrá hacer mrd. al dho. Don Gaspar tanbién abrá tenido fundamento para dar mayor expediente a las causas y negocios que se tratan en el Consejo de las Órdenes, pues siendo muchas el día de oy también es necesario que aya más jueçes y por este medio quedando en una persona el voto como juez y también las actiones de fiscal no se acrecienta nueva costa ni salario, pero en esta misma consideraçión es neçesario advertir que la experiencia tiene mostrado quan flojamente acuden al ministerio de fiscales los que sirven con título de consegeros, pues naturalmente el premio anima al travajo y le reusa el que se halla premiado de antemano, tomando muy acesoriamente y como de prestado la obligación principal del oficio que se exerçe sin proseguir las causas muy grabes y las que requieren para su inteligencia y buena directión, duración de tiempo sin dependencia de plaço fixo de donde 
Al disponerse el rey a resolver la consulta se enojó muchísimo, alegando no poder leerla:

«Estando para responder a los primeros capítulos desta consulta no he hacertado a lerosros, y assí será bien que la agais poner de buena letra y que adbirtáis a los secretarios que no escriban lo que no se puede ler, y porque me ba sucedido ya otra vez en consulta desse $\mathrm{Con}^{\circ}$. adbierto que son muchas»113.

El 14 de febrero de 1628 el Consejo de la Cámara volvió a reiterar la consulta de 8 de diciembre del año anterior, pero suprimiendo el último párrafo, que ahora queda redactado de la siguiente manera:

«Lo de ariva es copia de la consulta que se hizo a V.M. en 8 de Diciembre del año pasado, de la qual se ha quitado el último capítulo que V.M $M^{d}$. honrrando a este Consejo se ha servido de no haver acertado a ler y lo contenido en él se acordó en la Cámara que se propusiese a V.M. ${ }^{\mathrm{d}}$. pareciendo que era de la obligación, zelo y amor

nace estar desiertas las causas fiscales, padeçer mucho la causa pública las que se an de seguir de oficio, que si no ay quien las mueba son siempre las peor libradas.

La tercera que si lo dicho procede generalmente ay raçón más particular de inconvenientes en el fiscal del Consejo de las Órdenes, pues siendo la mayor ocupación de aquél tribunal la de los hávitos en ellos, es parte el dicho fiscal y se puede y debe interponer muchas veçes y juez y parte repugna a toda raçón y cesa la raçón de dar expediente a los negocios y fuera de menor inconveniente quando V. Mag ${ }^{d}$. mandara proveer juntamente la fiscalía, si bien esto demás del daño referido en lo general acrecienta costa que qualquiera es de consideración en el estado en que V. Mag ${ }^{\mathrm{d}}$. se halla y la consequencia que haçe para otros.

La quarta por que dando título de consegero al que actualmente haçe oficio de fiscal se causa mucha confusión y competencia en las ocasiones y actos públicos donde se concurre y porque si a de prebaleçer el exercicio de fiscal, a de ser preferido de otros consegeros, aunque sea de tribunales inferiores desta Corte y si el fiscal se a de considerar como consegero a de preferir a los fiscales de Consejo superiores y siendo así que el fiscal de las órdenes viene a defender su jurisdicción a la Sala de Govierno, muchas veçes donde asiste el que lo es del Consejo podría intentar preferirle biniendo como biene inferior en el exercicio y si bien este inconveniente cesa el día de oy porque también tiene Don Juan Chumaçero, fiscal título de consegero quedarán en pie las dificultades para diferentes actos y en los semejantes se a sentido este inconveniente y el dicho Don Juan no concurre el día que se publica la Bula, donde asiste el Consejo porque interbienen tanbién ministros del Consejo de Aragón y otros que sirven en la Cruzada.

Últimamente no repara la Cámara tanto en que sin preceder examen y consulta suya se ayan hecho las dos provisiones del dho. Don Gaspar y otras (por que esto se reconoce que privativa y personalmente es de la mayor regalía) como en los inconvenientes referidos y otros muchos que se dejan considerar y en esta presente aun no se ponderä la novedad y otros daños con que se desconsuelan los que están sirviendo por no parecer que se incurre en defensa de preeminencia propia. El servicio de V. Mag ${ }^{\mathrm{d}}$. a obligado solamente a deçir esto que mandará lo que más convenga». (AHN, Consejos, leg. 51.708)

113 AHN, Consejos, leg. 51.708 
de los que sirven en ella, representando a $\mathrm{V}$. $\mathbf{M}^{\mathrm{d}}$. por mayor bien de la causa pública y de su Real servicio. V. $\mathbf{M}^{\mathrm{d}}$. mandará en todo lo que sea servido»114.

De todos los reparos formulados por la Cámara, únicamente resolvió el rey el relativo a la fiscalización de los hábitos. Mandaba Felipe IV que la Cámara estudiara las ordenanzas del Consejo de Órdenes por si en ellas se regulaba algo sobre el control de los hábitos ${ }^{115}$. Una nueva consulta de la Cámara reconocía que en las ordenanzas del Consejo de Órdenes no se contemplaba que el fiscal interviniera en los hábitos, aunque era costumbre hacerlo ${ }^{116}$. Finalmente, el rey ordenó que se cumpliera el decreto concediendo al fiscal del Consejo de Órdenes una plaza supernumeraria de consejero. El nuevo consejero, Gaspar de Bracamonte, llegaría con el tiempo a presidir el Consejo de Órdenes ${ }^{117}$.

\footnotetext{
114 AHN, Consejos, leg. 51.708

115 La decisión real expresaba: «He mandado traer las ordenanzas del Cons ${ }^{\circ}$. de Órdenes para ver en ellas lo que se ordena al fiscal y en ninguna he hallado que se ordene el fiscalizar los ávitos como aquí presuponéis, con que pareçe que cesa el inconbeniente que havéis antepuesto, será bien que veáis estas ordenanzas por si se me a quedado alguna por ver y si no se hallare que haya de fiscalizar los ávitos, se hará lo que tengo mandado» (Rúbrica real). En AHN, Consejos, leg: 51.708.

116 «Vista esta respuesta de V. $\mathrm{Mg}^{\mathrm{d}}$. en la Cámara — decía ésta-, ha pareçido que antes de executarse lo que por ella se manda se deve advertir a $\mathrm{V} . \mathrm{Mg}^{\mathrm{d}}$. que aunque en las ordenanças del Consejo de las Órdenes no se diçe que el fiscal haga ofiçio de tal en los ávitos, es de su obligación y le toca y está en costumbre asentada de hazerlo y mostrarse parte en las causas dellos quando entiende que es menester y suele recusar al consegero o consegeros que le pareze conviene que no sean juezes de las informaçiones y otras diligençias que para ellos se hazen. Lo qual es cosa llana y ordinaria, como particularmente lo saven el cardenal Presidente y Don Alonso de Cabrera que tubieron aquella fiscalía, y quando no fuera parte ni tratara, como trata, estas materias, como fiscal quedavan en pie los otros inconvenientes, que en la consulta se representan de que en una persona estén juntos estos ofiçios, demás de ser en aquél Consejo muy pocos los pleytos entre partes y todo lo restante que es govierno y criminal, tocarle al fiscal, con que puede servir a pocos negoçios en el ofiçio de consegero, no faltando al de fiscal. Y en los títulos de los fiscales de otros Consejos y de las Audiençias ni en las Ordenanças de sus tribunales, tanpoco se dize en particular las cosas en que han de entender ocupar y defender y se conprehenden en solo el nombre de procurador y abogado fiscal, a quien toca todo lo que no es entre partes y se haze de ofiçio, como las informaçiones de ávitos. V. Mag $^{\mathrm{d}}$. mandará lo que fuere su Real Voluntad. En Madrid a 2 de marzo de 1628» (Cinco señales). En AHN, Consejos, leg. 51.708.

117 El título de presidente despachado a Bracamonte decía: «Por quanto el cargo de presidente de mi Conss ${ }^{\circ}$. de las Órdenes de Santiago, Calatrava y Alcántara, cuya administración perpetua yo tengo por autoridad apostólica, está vaco por muerte del Marq. de Miravel y combiene prover persona que le sirva y exerça, teniendo consideraçión a la prudençia, fidelidad y méritos que concurren en vos D. Gaspar de Bracamonte y Guzmán, conde de Peñaranda, cavo ${ }^{\circ}$ de la orden de Alcántara y Comendador de Daymiel, en la de Calatrava, Gentilhombre de mi Cam ${ }^{\mathrm{a}}$. de mis Consejos de Estado y Guerra y Cámara de Castilla y a los agradables y continuos serviçios que me havéis echo y espero que me haréis, de que me hallo con entera satisfación y entendiendo que así combiene a la buena administrazión y execuzión de la justiçia y vreve expediçión de los negoçios, tengo por bien que ahora y de aquí adelante por el tiempo que fuere mi voluntad seáis presidente del dho. mi Consejo de las Órdenes y hagáis y proveáis en todos los cassos y cossas tocantes al dho. cargo, según y
}

Hispania, LXIII/2, núm. 214 (2003) 657-744 
Otros siete consejeros - numerarios o no- serán nombrados por el rey mediante decreto, sin recabar consulta de la Cámara: Juan Chacón Ponce de León, comisionado al propio tiempo para convocar a la nobleza castellana para la guerra ${ }^{118}$; Juan de Carvajal, visitador de la Audiencia de Charcas ${ }^{119}$; Antonio de Aragón, como reconocimiento a los servicios de su padre el duque de Car-

de la manera que lo an echo, podido y devido hacer los demás presidentes que an sido del y por la presente mando a los del dho mi Conss ${ }^{\circ}$. que haviendo recivido de vos el juramento acostumbrado os ayan y tengan por presidente del y ussen con vos este cargo en todos los cassos y cossas a él anejas y concernientes y os guarden y hagan guardar todas las preheminençias, prerrogativas e ynmunidades y las demás cossas que como presidente del dho. mi Consejo devéis haver y goçar y os deven ser guardadas, según que mejor y demás cumplidamente se ussó y devió usar y guardar con los demás presidentes vuestros antecesores y es mi voluntad que llevéis de salario con el dho. cargo otros tantos maravedís como ellos llevaron y tenían señalados en mis libros de las dhas. órdenes y man ${ }^{\mathrm{do}}$. a mis contadores dellas y a sus thenientes, que os libren y hagan pagar este presente año de mill y seiscientos y cinquenta y uno lo que huviéredes de haver prorrata y desde allí adelante en cada un año de los que sirvieredes este cargo, a los tiempos según y de la manera que se libraron a los demás Preside ${ }^{\text {tes }}$. que an sido del dho. mi Conss ${ }^{\circ}$. y que se asiente el traslado de esta mi carta en los libros de las Contadurías de las dhas. órdenes y se os buelba original para que la tengáis por título del dho. cargo. Dada en Madrid a veinte y dos de febrero de mill y seiscientos y cinquenta y un años. Yo el Rey» (AGS, QC, leg. 20, fols. 853-854r $\mathrm{r}^{\circ}$.).

118 Un primer decreto concedió a Chacón la primera vacante que se produjera en el Consejo de Órdenes: «A don Juan Chacón Ponze de León he mandado que vaya a proseguir la comisión que se havía dado a don Álvaro Doca para la convocaçión de la nobleça de Castilla La Viexa para acudir a los acçidentes pres ${ }^{\text {tes. }}$. de Guerra, por haver ordenado a don Álvaro que se detenga por ahora en Navarra a cosas de mi servy ${ }^{\circ}$ y en consideraçión de lo que en esto me ha de hazer don Juan Chacón $\mathrm{y}$ de los que me tiene hechos, es mi vol ${ }^{\mathrm{d}}$. se le ofrezca la primera plaça que vacare en el Cons ${ }^{\circ}$. de las Órdenes. Tendrálo entendido la Cam ${ }^{\text {ta }}$. para quando llegue la ocasión" (Madrid, 4-III-1637). Otro posterior dispuso que se le despachase el título de nombramiento: «He resuelto por alg ${ }^{\text {as }}$. consideraçiones y satisfacçión con que ha servido y sirve Don Juan Chacón, de ordenar, como lo hago, se le despache luego el título de consexero del Cons ${ }^{\circ}$. de las Órdenes y que le corra la antigüedad desde el día del, pues le tengo hecha merced desta plaça antes de ahora, haréis que por la Cámara se le de este despacho" (Madrid, 15-VII-1637). En AHN, Consejos, leg. 51.708.

Según el cronista del reino de Aragón Pellicer, Juan Chacón se casó con Catalina de Ayala, «hermana del Señor Conde de Villalva, contra voluntad de los deudos de la novia» (PELLIZER Y TOBAR, J.: "Avisos históricos, que comprehenden las noticias y sucesos más particulares, ocurridos en nuestra Monarquía desde el año 1639", en VALLADARES DE SOTOMAYOR, A.: Semanario Erudito, que comprehende varios obras inéditas, críticas, morales, instructivas, políticas, bistóricas, satíricas y jocosas de nuestros mejores autores antiguos y modernos, Madrid, 1790, T. XXXI, aviso de 19 de julio de 1639, 51).

119 El decreto despachado al efecto dispuso: «Haviendo remitido a una Junta particular un memorial del Liz ${ }^{\text {do }}$. Don Juan de Carvajal sobre la pretensión que a tenido de que sin embargo de las dependencias que resultan de la visita de las Charcas en que estuvo, de que se conoce en el Consejo de Indias, devía continuar su plaça de consejero del, como los demás que allí sirven. En conformidad de la consulta que cerca desto me hiço, he resuelto entre otras cosas que sirva en el Consejo de Órdenes como los demás del, y respecto de que en entrar a servir en el dho. Consejo es como hacer un depósito de este ministro en el ínterin que, o buelve a servir en el Consejo de Indias, o se le hace otra merced, declaro que desta no debe media anata. En esta confor ${ }^{d}$. se le dará el despacho necesario» (Madrid, 25-XII-1639). AHN, Consejos, leg. 51.708.

Hispania, LXIII/2, núm. 214 (2003) 657-744 
dona $^{120}$; Jerónimo de Mascareñas ${ }^{121}$; Bernardo de Ipiñarrieta ${ }^{122}$; Francisco de Borja, en compensación por los servicios de su padre el duque de Villahermosa ${ }^{123}$; Marcos Tamariz de la Escalera, fiscal del propio Consejo de Órdenes ${ }^{124}$ y a Lope de los Ríos, regente del Consejo navarro ${ }^{125}$.

\section{C) Plazas supernumerarias}

Un decreto de 1622 creará una plaza supernumeraria con el fin de poner al día el excesivo volumen de trabajo pendiente y obligará a la Cámara a propo-

120 «A don Antonio de Aragón - decía el decreto-, en consideración de los servicios del Duque de Cardona, su padre, y por las buenas partes que concurren en su persona, le he hecho merced de plaza en el Cons ${ }^{\circ}$. de Órdenes. Darásele el despacho necesario para que entre luego a servirla» (Madrid, 20-IX-1640). AHN, Consejos, leg. 51.708.

121 El decreto mandando cumplir la merced de consejero de órdenes expresó: «Véase en el Consejo de la Cámara el membrete incluso que va señalado de don Fer ${ }^{\text {do }}$. de Contreras, y es lo que en substancia me consultó la Junta de $\mathrm{Ex}^{\mathrm{on}}$. y yo he resuelto sobre dar cumplimiento a la merced que tengo hecha del Conss ${ }^{\circ}$. de las Órdenes a Don $\mathrm{Ger}^{\mathrm{mo}}$. Mascareñas y executese mi resolución» (Madrid, 23-III-1641). AHN, Consejos, leg. 51.708.

${ }_{122}$ Un decretó otorgó a Ipiñarrieta la primera vacante que hubiere en el Consejo de Órdenes: «Haviendome dado quenta la Junta de Execución de la pretensión que la villa de Molina, su tierra y cavildo introdujo, de que la merced que hiçe al liz ${ }^{\text {do }}$. don Ver ${ }^{\text {do }}$. de Ipeñarrieta de Alcalde de Casa y Corte, sea de plaza de uno de los Consejos de Indias o de Órdenes por estar imposivilitado de poder servir la de Alcalde por sus achaques. He resuelto que si ay plaça vaca y es cierto el impedimento se le podrá dar una de Órdenes» (Madrid, 14-VII-1641). Posteriormente se dispondrá que «en conformidad de consulta de la Junta de Execución, he resuelto que la plaza del Consejo de Órdenes, de que tengo hecha merced a don Ber ${ }^{\text {do }}$. de Ipeñarrieta para quando vaque se le de con efecto desde luego, despachándole título della en la forma que se acostumbra, pues será muy posible la aya para quando don Ber ${ }^{\text {do }}$. se aya desembarazado y esté en disposición de poder entrar a servir» (Madrid, 22-VIII-1641). AHN, Consejos, leg. 51.708.

123 «A Don Fran ${ }^{\text {co }}$. de Borja, en consideración de las buenas partes que concurren en su persona y de los servicios del Duque de Villahermosa, su padre, le he hecho merced de plaza del Conss ${ }^{\circ}$. de Órdenes. Darásele el despacho necesario» (Madrid, 13-XII-1642). AHN, Consejos, leg. 51.708.

${ }^{124}$ Disponía el decreto: "Al lic ${ }^{\text {do }}$. Don Marcos Tamariz de la Escalera, fiscal del Conss ${ }^{\circ}$. de las Órdenes, he hecho merced, en consider ${ }^{\circ \mathrm{n}}$. de sus servicios, de plaza de consejero en el dicho Conss ${ }^{\circ}$. y de la fiscalía que por él vaca al lic ${ }^{\text {do }}$. Don Joseph Pardo, fiscal de la Chancillería de Vall ${ }^{\text {. }}$. en contemplaçión del casamiento que ha çelebrado con Doña Ana de Lezama, hija maior de Don Gerónimo de Lezama, mi $S^{\text {rio }}$. de la Guerra, y en $\operatorname{ex}^{\text {on }}$. de la que se le prometió con ocasión de su muerte, de plaza en Madrid en uno de los Consejos, para quien cassase con la dicha Doña Ana de Lezama, su hija maior. Daránseles a los dos los despachos que se acostumbra para su cumplimiento" (Madrid, 19-VIII-1650). AHN, Consejos, leg. 51.708.

${ }^{125}$ El decreto de nombramiento fue: «Teniendo consideración a los serviçios y méritos de Don Lope de los Ríos, Regente de mi Consejo de Navarra, a lo que los a aumentado en la ocasión presente de asistir mi Persona Real en la frontera a la concluss ${ }^{\text {on }}$. última de las Paces de mi Corona con la de Françia, y entrega de la infanta Doña María.Teressa, mi hija, al Rey xpmo. mi sobrino. He resuelto hazerle merced de Plaza del Consejo de las Órdenes. Tendráse enten ${ }^{\mathrm{do}}$. en la Cámara y darásele el despacho de que necesitare para su cumplimiento» (Burgos, 15-VI-1660). AHN, Consejos, leg. 51.708. 
ner, entre otros, al fiscal del Consejo de Órdenes Chumacero. El decreto dirigido al presidente del Consejo- dispuso:

«Aviéndoseme representado que en el Cons ${ }^{\circ}$. de las Órdenes ay muchos negoçios atrasados assí tocantes a informaçiones de hábitos, como de pleytos entre partes, visitas y residençias y que añadiendo una plaza supernumeraria, podría aver de ordinario dos Salas, y algunas vezes tres, con que se podría dar cabo a los dichos negoçios. He resuelto que se añada la dicha Plaça supernumeraria, por agora. Y assí me consultará la Cámara personas para ella, y entre otros, al licen ${ }^{\text {do }}$. don Juan Chumaçero, fiscal del mismo Cons ${ }^{\circ} .{ }^{126}$.

Con esta nueva plaza serán siete los consejeros: Juan Serrano Zapata, Antonio de Pedrosa, Juan Coello de Contreras, Juan Jiménez de Ocón, Luis de Villavicencio, Antonio de Castro y Juan Chumacero. La presidencia la ocupa Luis Carrillo y Toledo, marqués de Caracena ${ }^{127}$.

Dos años más tarde, el rey decretará que la Cámara no proponga para ninguna de las plazas vacantes en los Consejos y Tribunales de la Corte «acrecentadas a las que había en tiempo del Rey don Filipe $2^{\circ} .{ }^{128}$. Se trataba con ello de volver a la planta que tenían los tribunales en la época del Rey Prudente. Por lo que respecta al Consejo de Órdenes, eran cuatro los consejeros que en su reinado ocupaban plaza de número, luego con Felipe III se incrementaron dos plazas numerarias y otra supernumeraria ${ }^{129}$.

No se consiguió en el reinado de Felipe IV que hubiera solo cuatro consejeros de órdenes. Tanto es así que en 1647 conformaban el Consejo los siguientes nueve consejeros:

1.- Antonio de Luna

2.- Juan Girón y Zúñiga

3.- Diego Rodríguez Baltodano

4.- Antonio de Aragón

5.- Jerónimo Mascareñas

6.- Francisco de Borja y Aragón

7.- Pedro de Alarcón y Ocón

8.- Agustín del Hierro

9.- Antonio de Benavides

126 Madrid, 8-XII-1622 (AHN, Consejos, leg. 51.708).

127 GONZÁLEz DÁvila, Teatro de las Grandezas, 490.

${ }^{128}$ AHN, Consejos, leg. 51. 708.

129 Postigo, de manera incorrecta y confusa, expresa que en 1600 se incrementó una plaza de consejero de Ordenes, alrededor de 1628 otra, en 1656 la tercera y una cuarta en fecha que declara no conocer» (Postigo CASTELlanos, Honor y privilegio en la Corona de Castilla, 91). 
No obstante, lo decretado por Felipe IV en 1624, en reiteradas ocasiones proveerá plazas de consejero supernumerario de órdenes. Unas veces lo hará directamente a través de decreto ${ }^{130}$, y otras, previa consulta de la Cámara ${ }^{131}$. No quisiera dejar de analizar aunque sea someramente los singulares trámites de nombramiento de dos consejeros supernumerarios: Alarcón y de la Torre. El primero de ellos sería nombrado por recomendación de la Junta de Ejecución. En efecto, el 12 de agosto de 1642 expresaba ésta Junta que en consulta del Consejo de Guerra de 31-X-1640 se habían representado los servicios de Alarcón, oidor de la Chancillería de Valladolid, siendo de parecer que se le concediera plaza de asiento en la Corte. El rey se conformó con esta propuesta. Al propio tiempo Alarcón presentó memorial en la Junta de Ejecución suplicando que por sus servicios y en particular por la leva que había llevado a cabo de 400 infantes «para el Regimiento del príncipe» se le concediese plaza en la Corte. La Junta opinó «que por la inteligençia y çelo con que havía acudido a las ocasiones militares y levas de mar y guerra y por sus serviçios» el rey podría otorgarle alguna plaza, recomendándole al efecto a la Cámara. El 26 de agosto la Junta de Ejecución reiteró lo mismo, añadiendo que la Cámara le consultase. El 8 de octubre de 1642 ésta opinó que el rey podría concederle la merced de una plaza supernumeraria del Consejo de Órdenes, amortizándose la primera que vacare. El rey se adhirió a lo consultado por la Cámara: «Está bien» ${ }^{132}$.

El otro caso fue el de Alonso de la Torre, también oidor de la misma Chancillería y agente en Roma. Un decreto real le adjudicó plaza en alguno de los Consejos de la Corte:

«A Don Alonso de la Torre Iberna, oydor de la Chancillería de Valladolid y mi Agente en Roma, en consideración de sus letras y grados y por lo bien que ha servido y está sirviendo la dha. Agencia, le he hecho merced de que se le señale plaza en uno de los Tribunales desta Corte, y que desde luego venga a exercerla. El Consejo de la $\mathrm{Cam}^{\mathrm{a}}$. lo tendrá entendido y dará execución a lo referido»133.

Días después la Cámara respondió: "pareçe que siendo servido se le podría dar una plaça supernumeraria de Oydor en el Conss ${ }^{\circ}$. de las Órdenes»134. Felipe IV se conformó con la propuesta que formuló la Cámara.

En los títulos de nombramiento de los consejeros de órdenes supernumerarios, al contrario que en los de alcaldes de Casa y Corte y de consejeros de Castilla, no suele figurar el término supernumerario. De todos los títulos que he tenido ocasión de manejar en la sección de Quitaciones de Corte de Simancas,

\footnotetext{
${ }^{130}$ Más arriba apunté los casos.

131 Véase a este respecto en el anexo las consultas de 22-VI-1626, 20-III-1632, 8-X-1642, 9-VI1649, 14-IX-1650, 27-III-1653, 10-VII-1662, 28-I-1664, 26-III-1664, 15-IX-1664 y 5-VII-1665.

132 AHN, Consejos, leg. 51.708.

133 Madrid, 1-VI-1649 (AHN, Consejos, leg. 51.708).

134 9-VI-1649 (AHN, Consejos, leg. 51.708).
} 
solamente aparece el vocablo supernumerario en los títulos de Bracamonte y de Alarcón. El de éste último expresa al respecto, lo siguiente:

«Por hacer vien y merced a vos el Liz ${ }^{\mathrm{do}}$. Don Pedro de Alarcón de Ocón, $\operatorname{cav}^{\circ}$. de la dicha orden de Santiago, oydor que ha sido de la Chancillería de Valladolid y Gobernador de Asturias. Acatando vuestra sufiçiençia y avilidad, letras, méritos y buena conçiençia y entendiendo que assí conbiene a mi servio ${ }^{\circ}$. y a la buena Administraçión de mi justiçia, he tenido y tengo por vien que ahora y de aquí adelante quanto mi merced y volunt ${ }^{d}$. fuere seáis uno de los de mi Consejo de las dichas Órdenes, con plaça supernumeraria, a las que hubiere en él, con que en lugar della se consuma la primera que vacare y como tal (...)»135.

En los demás títulos de consejero supernumerario en los que no figura el término supernumerario, quizá se pretenda con ello que no se amortice la primera plaza vacante que se produzca en el Consejo de Órdenes.

\section{D) Destinos, ascensos y jubilaciones}

Los designados como consejeros de órdenes eran reclutados, en su inmensa mayoría, en alguna de las dos Chancillerías. Otros ocupaban una fiscalía del Consejo de Guerra, de la Cruzada o de Órdenes; algunas eran alcaldes de Casa y Corte o desempeñaban una regencia ${ }^{136}$. En cuanto a la promoción posterior, generalmente pasaban a los Consejos de Indias o de Castilla, o bien a la presidencia de una Chancillería.

Como se ha señalado, muchos de los fiscales del Consejo de Órdenes eran promovidos a consejeros del mismo: Juan Chumacero de Sotomayor, Fernando Pizarro, Antonio Briceño, Juan de Mendoza, Lope de Morales, Diego Rodríguez Baltodano, Claudio Pimentel, Diego Zapata, Marcos Tamariz, Miguel de Luna, Antonio de Riaño, Fernando de Arce, Francisco de Vergara, Baltasar de la Cueva, Gabriel de Chaves, Jerónimo de Morquecho, Jerónimo de Prado, y Antonio de Urrutia ${ }^{137}$. Tres fiscales no accederían a plaza de consejero: Pedro Ordóñez de la Real ${ }^{138}$, Rodrigo Jerónimo Pacheco ${ }^{139}$ y José Pardo de Figueroa $^{140}$. Era frecuente otorgar a los fiscales voto de consejero, e incluso, compa-

135 AGS, QC, leg. 36, fols. $21 \mathrm{r}^{\circ}$.

136 Véase a este efecto los apuntes biográficos de los consejeros en el anexo final. Para el iter profesional de los consejeros de Órdenes, POSTIGO CASTELlanOs, Honor y privilegio en la Corona de Castilla, 89-91.

137 Véase en el anexo sus apuntes biográficos.

138 Fiscal del Consejo de Órdenes, 30-I-1642. AGS, QC, leg. 37, fols. 1290-1293.

139 Fiscal del Consejo de Órdenes, 5-VIII-1646 y consejero supernumerario de Indias, 4-VII1647. AGS, QC, leg. 39, fols. 329-336.

${ }_{140}$ Fiscal del Consejo de Órdenes, 22-VIII-1650; fiscal del Consejo de Indias, 28-XI-1651; consejero de Indias, 31-XII-1652; fiscal del Consejo Real, 15-X-1657 y consejero de Castilla, 19-X1659. AGS, QC, leg. 24, fols. 36 5-386. En la relación de Ministros del Consejo de Órdenes desde el año 
tibilizar la fiscalía con una consejería, como fueron los casos de Gaspar de Bracamonte y de Diego Rodríguez Baltodano.

Pocos consejeros de órdenes no serían promovidos a otros puestos. Algunos de aquéllos fallecieron ocupando sus plazas: Antonio de Castro, Juan Serrano Zapata, Marcos Tamariz, Gregorio de Chaves, Bernabé de Andrade y Juan de Estrada. Felipe IV sólo concedió la jubilación a dos consejeros: Gregorio de Tovar ${ }^{141}$ y Juan de Ocón.

de 1589 al de 1680, custodiada en AHN, Consejos, leg. 51.708, no se incluye a Pardo entre los consejeros de Órdenes. Tampoco se encuentra su título en Quitaciones de Corte del Archivo de Simancas. En cambio, sí que estiman que fue consejero Fayard (Los ministros del Consejo Real de Castilla, 47), Schäfer (El Consejo Real y Supremo de las Indias, I, 368) y Postigo (Honor y privilegio en la Corona de Castilla, 108).

${ }^{141}$ La cédula concediendo la jubilación a Tovar expresó: « Por quanto vos el liz ${ }^{\text {do }}$. don Greg ${ }^{\circ}$. de Tovar, $\mathrm{cav}^{\circ}$. de la horden de Santiago, de el nuestro $\mathrm{q}^{\circ}$. de las Hórdenes, nos abéis echo relación que vuestro padre y abuelo sirbieron muchos años en la nuestra Audia. de Galiçia y Chançillería de Balladolid y Granada y en los nuestros Consejos de las Yndias y Órdenes y vos a ymitaçión suya nos abéis serbido de fiscal de la dicha Audia ${ }^{a}$. de Balladolid y de alcalde mayor de la de el nuestro reyno de Galiçia, donde hiçistéis ofiçio de rexente como más antiguo muchos años y después de oydor de las nuestras Audiençias de Valladolid y Granada, donde abéis sido el más antiguo y serbido las aussençias y bacantes de Presidentes de ella y últimamente en el dicho nuestro Consexo de las Hórdenes y que por buestra mucha edad y los muchos años que nos abéis serbido y lo que abéis trabaxado en ellos, os faltan ya las fuerças y salud que para proseguir en el son neçesarias y que el poco tiempo que os resta de bida lo deseais emplear y ocupar solamente en las cosas que tocan a vuestra alma y salbaçión con la quietud que esto requiere, suplicéndonos fuesemos serbido de conçederos liçencia para recoxeros, escusándoos de la ocupaçión, serbiçio y asistençia de la plaça que tenéis en el dicho nuestro Consejo de las Hórdenes y como quiera que por la mucha satisfaçión que tenemos de vuestra perssona, partes y serbiçios olgaramos que pudiérades asistir en él. Bista la particular ynstançia que abéis echo ss $s^{e}$. ello y las justas causas que representáis y por os honrar y açer merced en señal y muestra de tantos y tan buenos y agradables serviçios echos con la continuaçión, rectitud y limpieça que es notorio, abemos tenido por bien de concederos como por la press ${ }^{\text {te }}$. os conçedemos la liçencia que pedís con retençión de el título y salario de la dicha plaça en el dho. nuestro Consexo de las Hórdenes y de la cassa de aposento que por ella se os da y por que es justo que os sea guardado y se os guarde el honor y autoridad y lugar que por la dicha plaça se os debe, no obstante que dexéis de asistir personal y actualmente en ella, mandamos al Presidente y a los de el nuestro Consexo de las Hórdenes, que en los actos públicos de besarnos la mano, fiestas, proçesiones y otros os agan dar vuestro lugar y antigüedad y os libren y agan pagar el salario y creçimiento de la dicha plaça que se libra y paga por el dicho Consexo de las Hórdenes y Contadores de él y assí mandamos a los de el nuestro Consexo de Haçienda y Contaduría mayor de ella, que tanbién ellos os libren el salario y creçimiento que por el se os a librado y libra en la nómina y en el pagador de nuestros Consexos en cada un año durante vuestra bida, los unos y los otros según y de la manera y en el mismo lugar y antigüedad que hasta aquí y como se os librava si sirbiérades la dicha plaça y a los presidentes y oydores de las nuestras Audiençias, alcaldes y alguaciles de la nuestra Casa, Corte y Chançillerías y a los dhos. tribunales y a los Conçexos, justiçias, rexidores, caballeros, escuderos, ofiçiales y ombres buenos y personas particulares de qualquiera estado y condiçión que sean de todas las çiudades, villas y lugares de estos nuestros reynos y señoríos por donde pasaredes, estubiéredes y residiéredes, que os guarden y agan guardar assí en los asientos y lugares como en los demás que se ofreçiere todas las honrras, graçias, mercedes, franqueças y libertades, exsençiones, preminençias, prerrogati-

Hispania, LXIII/2, núm. 214 (2003) 657-744 


\section{REINAdo DE CARLos II}

Felipe IV fallece el 17 de septiembre de 1665 . El príncipe Carlos, su heredero, sólo tenía cuatro años de edad. En su testamento, aquél había designado a la reina madre, Doña Mariana, tutora del príncipe y mandaba que una Junta de Gobierno, dispuesta en el testamento, que la asesoraría en el despacho de consultas, memoriales, cartas y otros papeles ${ }^{142}$. Componían la Junta el conde de Castrillo y Cristóbal Crespí de Valladaura, presidentes, respectivamente, de los Consejos de Castilla y de Aragón; Baltasar Moscoso, arzobispo de Toledo; Pascual de Aragón, inquisidor general; el conde de Peñaranda —que había sido, recordémoslo, consejero y presidente del Consejo de Órdenes-y el marqués de Aytona, ambos consejeros de Estado. Como secretario actuaría Blasco de Loyola, secretario de Estado y del Despacho ${ }^{143}$. La reina regente, como veremos más adelante, resolvió las consultas del Consejo de la Cámara en las que proponía candidatos para consejeros de órdenes y, en ocasiones, dictaría decretos de nombramiento de éstos últimos, sin atender para nada a la Cámara. Doña Mariana resolverá probablemente siguiendo el consejo de la Junta de Gobierno.

\section{A) Nombramientos con consulta de la Cámara}

La regente decidió sobre nueve consultas del Consejo de la Cámara en las que se proponían candidatos a plazas del Consejo de Órdenes ${ }^{144}$. A comienzos de la regencia, el conde de Oropesa, presidente de ese Consejo, solicitará a la

bas e ynmunidades que por raçón de ser de el dho. nuestro Consejo de las Hórdenes y antigüedad en él se os guardaban, pudieran y debieran guardar, bien y tan cumplidamente como si actual y personalmente estubiérades y residiérades en él, sin os poner en ello ynpedimento alguno, que assí es nuestra boluntad y que tome la raçón de esta nuestra cédula, don Joan de Castillo, nuestro Secretario y de el rexistro de mercedes dentro de quatro meses primeros siguientes. Fecha en Madrid a diez y nuebe de agosto de mill y seiscientos y treinta y un años $=$ Yo el Rey $=$ Por mandado de el rey nuestro Señor don Gabriel de Ocaña y Alarcón = Tomé la raçón en beinte y ocho de agosto de mill y seiscientos y treinta y uno, don Joan de Castillo = Assentóse el traslado de la çedula de su mag $^{d}$. en la oxa antes de esta escrita en los libros de rentas de su Consexo y Contaduría mayor de haçienda como por ella se manda. En Madrid a treinta de agosto de mill y seiscientos treinta y uno, Gerónimo de Canençia» (AGS, QC, leg. 22, fols. 746-747 $\mathrm{r}^{\circ}$.).

${ }_{142}^{42}$ Yali Roman, A.: «Origen y evolución de la Secretaría de Estado y de la Secretaría del Despacho", en Jabrbuch fur gescbichte van stact wirts chafs und gesellsechaft la tenamerikas, $\mathrm{n}^{\circ} 6$, Colonia, 1969, 115. TOMÁS Y VALIENTE, Los validos, 18.

${ }_{143}$ DuQue De MaURA, Vida y reinado de Carlos II, Madrid, 1990, 53-61; BaLTAR RodríGuez, Las Juntas de Gobierno en la Monarquía Hispánica, 103-118 y RiBOT GARCIA, L. A.: «La España de Carlos II», en Historia de España Menéndez Pidal, dirigida por José María Jover Zamora, T. XXVIII, Madrid, 1994, 78-85. Sobre el cardenal de Aragón existe una monografía: EsTENAGA Y ECHEVARRÍA, N.: Estudio histórico sobre el cardenal de Aragón (1626-1677), 2 vols., París, 1929-1930.

${ }^{144}$ Las consultas fueron de 4-II-1669, 5-I-1671, 12-I-1671, 16-XI-1671, 27-I-1672, 4-V$1672,17-V-1673,27-X I-1673$ y 4-XII-1673. Véanse las propuestas en apéndice final. 
reina regente que Fernando Queipo, fiscal del mismo Consejo, debido a su inexperiencia en los asuntos fiscales, sea promovido a consejero supernumerario. En su consulta, del 14 de febrero de 1666, el conde proponía que:

«Fernando Queypo de Llanos, Ministro muy digno y graduado, por su calidad, por sus letras, larga asistencia de tribunales, integridad y justificaçión, pero respeto de no haver entrado en las plaças que ha servido, por el camino de fiscal, cuyo exercicio es diferente, y pide otro género de expedizión y estudio que el juzgar y votar los pleytos, se halla tan remoto y tan nuevo en las diligençias, instançias, y términos judiçiales a que obliga este manejo que se ha empeçado ya a experimentar 'el incombeniente de su falta de experiencia y se puede temer que la Jurisdiçión Real (cuya defensa toca positivamente al fiscal) no tenga en sus manos el cobro que conviene, y se atrasen o pierdan los negoçios que están a su cargo sin que lo pueda remediar mi cuidado ni el de los demás Ministros, particularmente debiendo concurrir con la nueba forma que se ha tomado en la Junta de competencias y así he tenido por de mi precisa obligazión el poner a V. Mag ${ }^{d}$. en consideraçión quanto conviene ocurrir a este inconveniente, siendo de pareçer (....) podría V. Mag ${ }^{d}$. servirse de honrrar los serviçios, y canas de Don Fernando Queypo de Llanos, mandando que pase a plaça de oydor, para cuyo exerçiçio le tengo por mucho más a propósito que para el de fiscal, mandando V. Magd. al mismo tiempo que el $\mathrm{Cons}^{\circ}$. de Cámara proponga sugetos para la fiscalía, con que dexará V. $\mathrm{Mag}^{\mathrm{d}}$. premiado a un sugeto digno y de satisfaçión (....)»145.

La reina mediante decreto, despachado el 19 de febrero de 1666, ordenaría a la Cámara que emitiera su opinión al respecto. La Cámara no era partidaria de que se crearan plazas supernumerarias y que el fiscal fuera propuesto en el futuro, cuando surgiera alguna vacante de número:

«A la Cámara se le ofrece representar a V. $\mathbf{M}^{\mathrm{d}}$. (como lo a hecho en otras ocasiones) que el aumentar plaças en los Consejos es contra las órdenes de V. $\mathrm{M}^{\mathrm{d}}$. y materia de inconviniente y de consequencia y mucho más en el Cons ${ }^{\circ}$. de las Órdenes, respecto de que la mayor parte de los salarios que goçan aquellos consejeros, está consignada en la mesa maestral, cuyas rentas perteneçen a juristas ynteresados y no alcançando (como no alcança) en mucha cantidad para darles satisfazión, ya se vee debe repararse todo lo pusible este perjuicio, tanto más que siendo el $\mathrm{n}^{\circ}$. de plaças que debe tener el $\mathrm{Con}^{\circ}$. de las Órdenes de solos seis ministros, son ocho las que oy se hallan proveydos y sirviendo, respeto de que Don Antonio de Venavides que asistía a la Congregación de las Iglesias ha cesado en esta ocupación y por consiguiente el motivo más principal que se representava por los Presidentes de Órdenes para pedir se proveyese una plaça más como se hiço, mandando se consumiese en la primera vacante fuera de estas plaças está goçando otra Don Gerónimo Mascareñas, con que son tres las que fuera del $n^{\circ}$. consumen gages; y si ahora se aumentase otra teniendo prelación a los juristas estos salarios

$145 \mathrm{AHN}$, Consejos, leg. 51.708. Los documentos que manejo seguidamente se encuentran en este legajo, por ello evito citas reiterativas y para cuya comprobación remito al mismo. 
el daño sería considerable $=Y$ no dexa de reparar la Cámara que por el medio de esta proposición se quiera en caminar la mudança o promoción del fiscal a consejero y así atendiendo a todo la Cámara es de parecer que por ahora no debe $\mathrm{V}$. $\mathbf{M}^{\mathrm{d}}$. añadir ninguna plaça y que quando llegue el caso de proveerse se tendrán presentes los méritos de Don Fernando Queypo»146.

Doña Mariana se conformó con lo que propuso la Cámara. Su resolución fue la siguiente:

«Está bien lo que pareze. Y respeto de que este sujeto es más a propósito para juez que para fiscal, tendrá quenta el Consejo de proponérmele en la primera ocasión para quitar qualquier inconveniente que esto pueda tener».

El 23 de junio de 1667, el conde de Oropesa elevaba a la reina una consulta en la que explicaba el atraso que experimentaban los negocios del Consejo de Órdenes por faltar jueces y volvía a pedir que se concediera voto de consejero al fiscal. En su vista, la reina expidió el 3 de julio el siguiente decreto al presidente del Consejo de Castilla:

«El Conde de Oropesa en la consulta inclusa buelve a representar la gran necesidad que ai de añadir un consexero más en el Consexo de Ordenes, y quan preciso es poner otro fiscal en lugar del que oy ay, para el mejor expediente de los negocios, proponiendo que a Don Fernando Queipo de Llanos, que sirve esta plaza, se le de voto de consexero. Remítola à la Cámara para que con inteligencia de que es inescusable proveer la fiscalía, vea la forma en que se podrá acomodar a Don Fernando, atendiendo a lo que el Conde refiere de ser menester añadir ministro al Cons ${ }^{\circ}$. de Órdenes, y se me consulte sobre todo lo que se ofreciere y pareciere».

En ejecución del antecedente decreto, la Cámara consultaría el día siguiente a la reina expresando nuevamente que no era conveniente crear una plaza supernumeraria de consejero de órdenes, pero, atendiendo a los motivos que aducía el conde como eran el de ausencia de jueces y la falta de preparación del fiscal, le parecía «que por esta vez y lo que mira a esta causa y con calidad de suprimirse en la primera vacante podría V. Magd. servirse de que se provea una plaça más de las que oy tiene aquél $\mathrm{Cons}^{\circ}$. y si V. Mag ${ }^{d}$. lo resolviere así, propondrá este $C{ }^{\circ}{ }^{\circ}$. sugetos para ella y entonces atenderá a la pers ${ }^{\mathrm{a}}$. de Don Fernando Queypo llegando el caso de proveerse».

La reina daría satisfacción a la demanda del conde de Oropesa al decidir nombrar, sin esperar a las propuestas de la Cámara, a Fernando Queipo como

146 Consulta del Consejo de la Cámara, Madrid, 15-III-1666. Acordaron esta consulta, además del presidente, los camaristas Antonio de Contreras, Juan de Góngora y Juan de Carvajal (AHN, Consejos, leg. 51.708). 
consejero supernumerario de Órdenes; eso sí, mandó que la Cámara propusiera sujetos para la fiscalía que dejara vacante Queipo ${ }^{147}$.

Carlos II cumplió catorce años el día 6 de noviembre de 1675. El día siguiente una consulta conjunta de los Consejos de Estado y de Guerra indicaba al rey que firmara los decretos, pero asesorándose de la Junta de Gobierno durante dos años ${ }^{148}$.

Cuando el monarca tome las riendas del poder incrementará dos plazas numerarias en el Consejo de Órdenes: el decreto de 16 de diciembre de 1677 mandó que la Cámara propusiera jueces para una nueva plaza que convenía crear para garantizar el mejor expediente de los negocios de aquél Consejo y por resolución a consulta de la Cámara de 18 de enero de 1678 el rey nombró para otra plaza a Francisco Moscoso. No obstante, cuando el dos de enero de 1679 la Cámara solicitó al rey que se creara otra plaza de oidor, Carlos II no accedió a ello ${ }^{149}$. Pero, paradójicamente, unos meses después se concederá una consejería supernumeraria a Andrés de Riaño ${ }^{150}$.

${ }_{147}$ La resolución regia fue como sigue: «Hágase assí luego, quanto a la proposición de la plaza de fiscal, dándose la del Consejo de Órdenes a D. Fer ${ }^{\text {do }}$. Queipo de $\mathrm{q}^{\mathrm{e}}$. le hago merced, con la calidad que se me propone» (Rúbrica de la reina). AHN, Consejos, leg. 51.708.

148 DUQUe De MAURA, Vida y reinado de Carlos II, 168. No obstante, como señala Baltar, «el nombramiento de Valenzuela como primer ministro supuso en la práctica la disolución de la Junta que fue oficialmente certificada por un Real Decreto de 22 de septiembre de 1676, lo que no hacía más que confirmar la inoperancia de la misma» (BALTAR RODRíGUEZ, Las Juntas de Gobierno en la Monarquía Hispánica, 117).

149 «Reconociendo la Cámara — decía la consulta — que hace falta otro ministro (había siete) para formar dos Salas que son muy necesarias para la expedición de los nego ${ }^{s}$. de aquél Conss ${ }^{\circ}$. por que en la que se despachan pruebas se ocupan quatro, y uno en la guerda (sic) del contagio y por los accidentes de enfermedad de alguno, estando limitado el número cesa el despacho; añadiéndose a esto la instancia que hace el Duque de Sesa, Presidente de aquél Conss ${ }^{\circ}$. para que se provea otra plaza con estos motivos.

Por todo lo qual es de parecer la $\mathrm{Cam}^{\mathrm{ra}}$. que combiene se augmente otra plaça de oydor en lugar de Don Pedro Sarmiento que passó a fiscal del Conss ${ }^{\circ}$. en que no se acrecientan gages, pues no los goça D. Francisco de Moscosso, con la que exerce».

La resolución regia fue: «Pues ay al presente en este Consejo aún más Ministros de los de su instituto, y la ocupación del que asiste en la puerta a la guardia del contagio se debe esperar en Dios cesará con brevedad, no se necesita de nombrar otro» (AHN, Consejos, leg. 51.708).

150 Los trámites de esa concesión fueron de la siguiente manera. Andrés de Riaño presentó al rey un memorial relatando que se encontraba «sin crédito ni forma de mantenerse» por haber sido excluido de la plaza que desempeñaba de consejero de Hacienda y solicitaba un puesto en el Consejo de Órdenes. Por decreto de 13 de mayo de 1679 remitió a la Cámara el memorial de Riaño para que en su vista consultara lo que se ofreciere. Cinco días después, a la Cámara, «atendiendo al desconsuelo con que se halla al fin de sus años», le parecía que «puede V. $\mathbf{M g}^{\mathrm{d}}$. servirse de hacerle merced de la plaza del Conss ${ }^{\circ}$. de Órdenes que pide, aunque no la aya vaca, pues respecto de que Don Francisco Moscosso sirve la suya sin gages, no augmenta gastos y V. $\mathrm{Mg}^{\mathrm{d}}$. honrra y consuela a este sugeto en lo último de su vida, manifestando lo acepto que son a $\mathrm{V} . \mathrm{Mg}^{\mathrm{d}}$. sus muchos méritos y buen deseo de continuarlos» (Consulta de la Cámara, Madrid, 18-V-1679, en AHN, Consejos, leg. 51.708). El rey se conformó con lo consultado por la Cámara.

Hispania, LXIII/2, núm. 214 (2003) 657-744 
Las resoluciones tanto de la reina regente como de Carlos II a las consultas del Consejo de la Cámara las escribe el secretario del Despacho Universal y las rubrica uno de aquéllos. Según un Fragmento anónimo ${ }^{151}$, los presidentes de los diversos Consejos remiten directamente al «quarto» del rey las consultas. Después, el secretario del Despacho Universal estudia las consultas y expone el asunto al rey, quien decide. Una vez formalizado el decreto y rubricado por el monarca, se enviará la consulta al presidente del respectivo Consejo ${ }^{152}$.

En 1684 Carlos II regulara la planta definitiva del Consejo de Órdenes. Un primer paso lo constituye el decreto dirigido al presidente del Consejo de Castilla en verano de aquél año, en el que se mandaba a la Cámara que informara sobre la plantilla ideal de aquél Consejo:

«Sin embargo de haver resuelto - expresaba el decreto- y mandado se conserven en la nómina del Consejo de Órdenes, solos los salarios del Presidente, los seis Consejeros más antiguos, del Secretario y del Fiscal, y que los de los demás Ministros que en el ay, se consignen en otros efectos de la $R$. Haçienda (aunque sea en la nómina general de los Consejos) en el ínterin que determino el punto de conservarlos o suprimirlos; quiero estar enterado del número de Plazas, que combendrá quede por pie fijo en aquél Consejo, y assí ordeno a la Cámara me informe luego de ello» (Rúbrica real) ${ }^{153}$.

A finales de agosto informó la Cámara que se podría fijar la planta del Consejo de Órdenes en ocho consejeros y un fiscal. En ese momento prestaban sus servicios un total de diez consejeros ${ }^{154}$. El rey se conformó con la propuesta de la Cámara y mandó que «las dos plazas que ay de más deste número se extingan precisamente en las primeras vacantes, sin que con ningún pretexto se altere esta resolución».

El propio rey no cumplió su resolución. En 1686 designará, como veremos más adelante, dos consejeros supernumerarios: Sarmiento y Portocarrero. De ahí que decidiera dictar otro decreto a comienzos del año siguiente mandando que en lo sucesivo sólo hubiera los ocho consejeros numerarios establecidos en la planta de 1684:

«Siendo tan de mi serviçio el ir reduçiendo los Tribunales al pie que deven tener, así por escusar la maior dilaçión que el creçido número de Ministros causa al breve expediente de los negoçios, como por el gasto de los salarios que se augmentan, quando tanto se debe atender a minorarle; he resuelto que en el Consejo

${ }^{151}$ El Secretario de Estado y del Despacho Instruido. Su origen en España, sus funciones, ejercicio, máximas y manejos; su dirección, bonores y preeminencias, custodiado en la Real Academia de la Historia, manuscrito 9-26-1-D-7 y publicado por EscuDERO, J.A.: Los secretarios de Estado y del Despacho, $2^{\circ}$ ed., Madrid, 1976, T. IV, 1188-1275.

152 El Secretario de Estado y del Despacho Instruido, 1221.

153 Madrid, 17-VIII-1684 (AHN, Estado, leg. 6406, doc. 151).

${ }^{154}$ Consulta de la Cámara, Madrid, 30-VIII-1684. (AHN, Estado, leg. 6406, doc. 152). 
de las Órdenes, no haia más Plazas de número que ocho y el fiscal, y que no se me consulte supernumeraria para él, con ningún motivo ni pretexto : pero por ahora es mi voluntad se mantengan las que ay de más del número de las ocho, en la forma que están conzedidas, las quales se irán consumiendo, como fueren vacando hasta que queden en el número de ocho y el fiscal como va referido. Tendráse entendido assí en la Cámara, para su observançia (rubricado)»155.

¿Cumplió, por fin, Carlos II esta nueva resolución? A ello hemos de responder que tampoco. En efecto, en 1690 el rey designará por decreto a dos consejeros supernumerarios ${ }^{156}$ y en 1697 manda a la Cámara que consulte para una plaza supernumeraria ${ }^{157}$ y también nombra directamente a otro consejero fuera de la planta ${ }^{158}$.

\section{B) Nombramiento por decreto}

En el reinado de Carlos II se utilizó frecuentemente para designar a los consejeros de órdenes la vía directa del decreto, omitiendo el trámite de la consulta de la Cámara. Fueron designados directamente por decreto diecisiete consejeros. De ellos, catorce supernumerarios y el resto ocuparía plaza de número. Los supernumerarios fueron los siguientes:

\section{1.- Melchor de Cevallos, yerno de la azafata del rey:}

«Con atención a lo que ha servido $\mathrm{D}^{\mathrm{a}}$. Ana María Giner, Azafata del Rey mi hijo y a lo que está mereciendo este exercicio; y a los méritos y servicios que también concurren en Don Melchor de Cevallos El Cavallero, su hierno; le hago merced de Plaza supernumeraria de consexero del Consejo de Órdenes, con calidad de que aia de extinguirse la primera que vacare del numero. Tendráse entendido en la Cámara y darásele el despacho necesario a su cumplimiento» (Decreto, 15-XII-1674).

15s Decreto dirigido al presidente del Consejo, Madrid, 31-I-1687 (AHN, Estado, leg. 6406, doc. 156).

156 Los alcaldes de Casa y Corte Medrano y Miranda, que continuarían percibiendo sus salarios de alcaldes hasta que optaran a plaza numeraria de consejeros. El Consejo de Órdenes les abonaría las propinas y casa de aposento. Véase más adelante el decreto de nombramiento de los mismos.

157 El decreto que despachó a la Cámara disponía:

«Aunque para el número de consegeros de que a de componerse el Consejo de Órdenes, según la planta que le está dada no falta oy más que una Plaza, atendiendo a la falta de salud de algunos de los Ministros que le componen y a la más breve expedición de los negocios. Mando a la Cámara me consulte para dos, con calidad de que a de extinguirse precisamente la supernumeraria en la primera vacante y la encargo muy particularmente la atención y cuidado en la proposición de sugetos para ellas, por lo que importa, y se necesita que sean muy a propósito y de entera satisfacción en letras, y experiencias» (rúbrica real). En línea separada y tendida : En Madrid a 3 de Mayo de 1697. Al pie : Al Governador del Consejo. AHN, Estado, leg. 6406, doc. 162.

158 A Carlos de Borja, del que se puede ver su decreto de designación más adelante.

Hispania, LXIII/2, núm. 214 (2003) 657-744 


\section{2.- Jerónimo de Villamayor:}

«En atención a los méritos y servicios de Don Gerónimo de Villamayor, y de la satisfación con que los ha continuado en los empleos que ha tenido, le he hecho merced de la Plaza de Consejero de las Órdenes, que vacó por haver pasado el Adelantado de la Florida al de Indias, sin embargo de que quando se nombró a Don Melchor se previno se huviese de consumir la primera que vacase en aquel Consejo. Tendráse entendido en la Cámara, y me propondrá personas para la fiscalía de Ordenes, que vaca por $\mathrm{D}^{\mathrm{n}}$. $\mathrm{Ger}^{\mathrm{m} \text {. }}$. en la forma que se acostumbra» (Decreto, 7-XI-1675).

\section{3.- Manuel Coloma, embajador de la República de Génova:}

«En atención a los méritos y servicios que concurren en $\mathrm{D}^{\mathrm{n}}$. Manuel Coloma, a quien he nombrado por embiado a la República de Génova; he resuelto hazerle merced de plaza supernumeraria en el Consejo de Órdenes, para que pase más condecorado a servir aquel empleo, y que los gajes que debe percivir por razón della, reduciéndose a la moneda de allá, se los paguen con su sueldo, por no cargarse más la consignación de los Maestrazgos. Tendráse entendido assí en la Cámara, y se dará en esta conformidad el despacho necessario para su cumplimiento» (Decreto, 15-I-1677) 159 .

4.- Alonso Rico de Villarroel, ex vicario de Madrid:

«Para la mejor y más breve expedición de los negocios que se ofrecen en el Conss $^{\circ}$. de las Órdenes, y que no se retarden por falta de juezes, respecto de hallarse ausente Don Manuel Coloma; he benido por conveniente se provea una plaza más en él, para la qual he nombrado a Don Alonso Rico de Villarroel, que ha sido Vicario de Madrid, con calidad que se aya de consumir la primera que vacare. Tendráse entendido en la Cámara y darásele el despacho que se acostumbra» ${ }^{160}$.

\section{5.- El conde de Montezuma, oidor de la Chancillería de Granada:}

«Al Conde de Montezuma, Oydor de la Chan ${ }^{\text {ria }}$. de Granada, he hecho merced en atenzión a sus servizios y a los del Obispo Inqq ${ }^{\text {or }}$. Gnarl. su tío, de Plaza del Conss ${ }^{\circ}$. de las Órdenes, sirviéndola desde luego sin gages. Tendráse entendido en la $\mathrm{Cam}^{\mathrm{ra}}$. y darásele el despacho que se acostumbra» (Decreto, 24-VI-1681).

\section{6.- Baltasar de Mendoza, oidor de la Chancillería de Granada:}

«En consideraçión a los méritos y serviçios de $\mathrm{D}^{\mathrm{n}}$. Balthasar de Mendoza y estarlos continuando al presente de Oydor, de la Chançillería de Granada, le hago merced de Plaza supernumeraria del Consexo de las Órdenes, extinguiéndose la primera que vacare. Tendráse entendido en la Cámara, y se le dará el despacho nezesario para su cumplimiento» (Decreto, 10-X-1681).

159 Los tres decretos en AHN, Consejos, leg. 51.708.

${ }_{160}$ Decreto, Madrid, 20-I-1681 (AHN, Estado, leg. 6406). Los diez decretos que transcribo a continuación se custodian en el mismo legajo.

Hispania, LXIII/2, núm. 214 (2003) 657-744 


\section{7.- El agente general en Roma Bernardo de Quirós:}

«A D ${ }^{n}$. Francisco Bernardo de Quirós, mi Agente General en Roma, hago merced, en attención a sus servicios, de Plaza supernumeraria del $\mathrm{Conss}^{\circ}$. de las Órdenes, con los gages de ella, situados en la Presidencia de Hacienda. Tendráse entendido en la Cámara y darásele el despacho que se acostumbra, con calidad que se ha de extinguir la primera que vacare» (Decreto, 31-V-1684).

\section{8.- Antonio Sarmiento, oidor de la Chancillería de Granada:}

«Haviéndome representado el Duque de Sesa tiene por muy preciso que con motivo de la muerte de Don Luys de Cañas, que era del Conss ${ }^{\circ}$. de las Órdenes, se provea otro Ministro en su lugar, respecto de que no ay en él otro de la Orden de Calatrava, debiendo aver dos de cada una, conforme a las constituziones. Y para el más breve de los negocios que concurren, he venido en ello, y nombrado para esa Plaza a D. Antonio Sarmiento y Toledo, Oydor de Granada, por la satisfación con que me hallo de sus méritos y servicios, para que la sirva sin gages, hasta que entre al goze de ellos en Plaza numeraria, la primera que vacare. Tendráse entendido en la Cámara y darásele el despacho necesario a su cumplimiento en esta conformidad» (Decreto, 8-I-1686)161.

\section{9.- El conde de Obedos:}

«Con ocasión de la ausencia que Don Manuel Coloma ha de hacer a Olanda, donde está nombrado por embiado extraordinario; he hecho merced a Don Antonio Portocarrero, Conde de Obedos, de Plaza supernumeraria del Conss ${ }^{\circ}$. de las Órdenes, sin gages ni emolumento alguno hasta que entre por su antigüedad en Plaza del número. Tendráse entendido en la Cámara, y darásele en esta conformidad el despacho que se acostumbra» (Decreto, 20-VIII-1686).

\section{0.- Los alcaldes de Casa y Corte Medrano y Miranda:}

«Teniendo consideración a los méritos y servicios de D. García de Medrano, y de Don Rodrigo de Miranda, Alcaldes de mi Casa y Corte; y por el motivo particular de aver ido a las disposiciones de la jornada de la Reyna hasta venir a Madrid; les he hecho merced de Plazas del Conss ${ }^{\circ}$. de las órdenes supernumerarias con calidad, que no ayan de gozar más gages que los que oy tienen como Alcaldes y en la mesma situación, hasta que vaquen Plazas del número; pagándoseles solamente, por el Conss ${ }^{\circ}$. de Órdenes, las propinas, y casas de aposento, en los efectos que los demás Ministros del lo gozan. Tendráse entendido en la Cámara y

${ }^{161}$ A instancia del propio Sarmiento, el rey le concedería el año siguiente la fiscalía del Consejo de Órdenes. Sarmiento solicitó la plaza por carecer de medios económicos. La Cámara había expresado tener «por cierta la falta de medios que padece Don Antonio Sarmiento de Toledo, y para que pueda ocurrir a ello parece que V. $\mathbf{M g}^{d}$. puede servirse de mandar se le encargue la fiscalía del Consejo de las Órdenes, con el goze, que la corresponde hasta que entre en los gages y por vacante en la plaza del número» (Consulta de la Cámara, Madrid, 13-II-1687. AHN, Estado, leg. 6406). 
daráseles en esta conformidad los despachos necesarios; y la preferencia a D. García de Medrano» (Decreto, 22-V-1690).

\section{1.- El fiscal del Consejo de Guerra Zárate:}

«Atendiendo a la falta de Ministros que oy se experimenta en el Consejo de Órdenes para la expedición de los negocios, por la crecida edad y poca salud de algunos de los Ministros, que le componen. He resuelto que demás de la plaza que ha vacado por el Conde de Motezuma, y va proveída en otro decreto de la fecha de este, se augmente otra más y nombro para ella a Don Ignacio de Zárate, fiscal del Consejo de Guerra. Tendráse entendido en la Cámara y darásele el despacho que se acostumbra, y respecto de venir a quedar oy aquel Consejo con una Plaza mas de las de su dotación, se suprimirá la primera que vacare, y no se pasará a proponerme sugetos para ella. Executarese assí» (Decreto, 21-XI-1695).

\section{2.- Carlos de Borja, Sumiller de Cortina:}

«Atendiendo a la calidad y méritos de Don Carlos de Borja, mi Sumiller de Cortina, al que executó, como Capellán y Limosnero mayor, en el viage de la Reyna a España, y a los particulares, y agradables servicios de la Casa de Borja, le hago merced de plaza, supernumeraria, del Consejo de las Órdenes con gages, en el interin, que se le sitúan en renta eclesiástica. Tendráse entendido en la Cámara, y se le dará el despacho necesario en esta conformidad» (Decreto, 30-XII-1697).

\section{3.- El fiscal del Consejo de Guerra Doriga:}

«A Don Andrés Doriga, fiscal del Consejo de Guerra, he hecho merced, en atención a sus méritos y buenas prendas, de la plaza que ha vacado en el Consejo de Órdenes, por muerte de Don Christóbal de Chaves, con calidad de que le haia de preceder Don Matheo Ibáñez, fiscal del mismo Consejo, a quien he concedido honores de él. Tendráse entendido en la Cámara» (Decreto, 29-X-1698).

En principio, los consejeros supernumerarios realizaban idéntico trabajo que los numerarios, percibiendo el mismo sueldo. No obstante, se nombraron, como hemos visto en alguno de los decretos anteriores, supernumerarios sin «gajes» (salario): conde de Montezuma, Antonio Sarmiento y conde de Obedos.

Tres fiscales del Consejo de Órdenes ascendieron a consejeros del mismo utilizando el mecanismo de decreto y ocupando plazas de número: Rodrigo Portocarrero ${ }^{162}$, Luis de Silva ${ }^{163}$ y Pedro Nicolás de Orellana ${ }^{164}$.

${ }^{162}$ El decreto de nombramiento, rubricado por doña Mariana, dispuso: «Atendiendo a los méritos y partes que concurren en la persona de Don Rodrigo Portocarrero, Fiscal del Consejo de las Órdenes, le he hecho merced de una de las dos Plazas de Oidor que están vacas en él. Tendráse entendido en la Cámara y darásele el despacho que se acostumbra» (Madrid, 29-I-1672. AHN, Consejos, leg. 51.708).

${ }_{163}$ El decreto que se despachó fue: «A $\mathrm{D}^{n}$. Luis de Cañas y Silva, Fiscal del Consejo de Órdenes, le he hecho merced de Plaza entera en él, en atención a sus méritos y serviçios. Tendráse entendido 
A otro fiscal, Villamarín, se le concedió voto de consejero con el decreto siguiente:

«A don Luis Francisco de Villamarín he hecho merced, en atención a sus servicios, de voto en el Consejo de las Órdenes, juntamente con la fiscalía que está exerciendo y sin más gages que los que por ella tiene; y assí mando que por la Cámara se le de el despacho en esta conformidad»165.

La Cámara se quejó en reiteradas ocasiones de los nombramientos que realizaba el rey sin impetrar previo dictamen a la misma. Su malestar procedía, de un lado, por que esos nombramientos vulneraban las expectativas de promoción de jueces que habían desempeñado los diferentes escalones de la carrera judicial y, de otro, por que se gravaban las rentas de la mesa maestral. Especial gravedad revestía la designación cuando recaía en alguien que no pertenecía a la carrera judicial. A este propósito, cuando Carlos II nombró a Alonso Rico de Villarroel, ex vicario de Madrid, la Cámara respondió:

«(....) Y venerando la Cámara, como debe, las soberanas resoluciones de V. $\mathrm{Mg}^{\mathrm{d}}$. no puede dejar de hacer presente a $\mathrm{V}$. $\mathrm{Mg}^{\mathrm{d}}$. que por las obligaciones de su instituto en que la pusieron los gloriosos progenitores de $\mathrm{V}$. $\mathrm{Mg}^{\mathrm{d}}$. con las órdenes $e$ instrucciones que le regulan, y la continuada conseqüencia de los exemplares de haver hecho representación a V. $\mathrm{Mg}^{\mathrm{d}}$. en el caso de semejantes mercedes, debe poner en la real consideración de $\mathrm{V}$. $\mathrm{Mg}^{\mathrm{d}}$. que en esta concurren motivos de toda reflexión que manifiestan sus conocidos inconvenientes. Pues siendo las plazas de los Consejos de la Corte para los sugetos que siguiendo la regularidad de los estudios, experimentados en la práctica de las Chancillerías, donde se califican, se sigue grave perjuicio a la causa pública de que recaigan en quienes no ayan precedido estas circunstancias, resultando también en mucho desconsuelo de los beneméritos, que por estos medios miran más retardados sus ascensos. A que se añade el reparo de aumentar plazas que tanto se prohive por las ordenes antiguas, y modernas, mayormente en este Consejo, donde la mayor parte del goçe está consignado en la Mesa Maestral, cuyas rentas pertenecen a juristas perjudicados, en que se apliquen a otros gastos»166.

\footnotetext{
en la Cámara, y darásele el despacho neçesario a su cumplimiento" (San Lorenzo, 27-X-1680. AHN, Consejos, leg. 51.708).

164 «Hallándose oy vaca - expresaba el decreto- la Plaza del Consejo de Órdenes que tenía el Conde de Motezuma; he venido en ascender a ella a Don Pedro Nicolás de Orellana, fiscal actual del mismo Consejo. Tendráse entendido en la Cámara, y darásele el despacho que se acostumbra» (Madrid, 21-XI-1695. AHN, Estado, leg. 6406).

165 Madrid, 14-I-1687 (AHN, Estado, leg. 6406).

166 Consulta del Consejo de la Cámara, 23-I-1681 (AHN, Estado, leg. 6406).
} 


\section{CONCLUSIONES}

Cuando se produce una vacante en el Consejo de Órdenes, Felipe III casi siempre recabará la correspondiente consulta al Consejo de la Cámara, para que proponga candidatos para la plaza en cuestión. De las ternas que ésta elabora, el rey elige indistintamente a cualquiera de los propuestos. La resolución la escribe él directamente.

En alguna ocasión, el consejero es designado en virtud de la denominada resulta, esto es, en el momento que el rey resuelve una consulta para otra plaza, aprovecha e introduce a alguien en la vacante que se produzca por la promoción de un consejero de Órdenes a otro puesto.

Este monarca nombrará a veintiún consejeros, todos ellos procedentes de la carrera judicial, prefiriendo en la elección a los fiscales del propio Consejo de Órdenes. El duque de Lerma alguna vez recomendará a «hechuras» suyas para aquéllas plazas.

Con Felipe IV, la Cámara continúa proponiendo para las vacantes del Consejo de Órdenes, aunque el método de provisión experimentará dos cambios. El primero tiene lugar a comienzos del reinado, cuando es derogado el sistema de ternas, concediendo libertad a los camaristas para que propongan en cada uno de los puestos de la consulta hasta tres candidatos y, el otro en 1643, al restablecerse nuevamente las ternas en la Cámara. El monarca designará frecuentemente al candidato propuesto en primer lugar en la consulta e incluso, en ocasiones, a alguien que no figura en la misma. En las votaciones de las consultas, que salvo en tres casos serán públicas, si había algún candidato emparentado con un camarista, éste se ausentaba, eso sí, una vez que hubiera votado.

Felipe IV trató de reducir las plazas de consejeros a las cuatro que existían en tiempos del rey prudente. No obstante sus buenos deseos, no lo logrará, recurriendo a partir de 1622 a la figura de los consejeros supernumerarios. Hasta ocho veces nombró aquél consejeros, algunos de esta clase última, valiéndose del decreto y omitiendo, de esta manera, la consulta previa de la Cámara.

Al Consejo de Órdenes se llega después de haber desempeñado muchos años un puesto en alguna Audiencia o Chancillería, ocupando muchos de ellos primeramente una fiscalía de ese Consejo, para luego pasar a una consejería. Excepción a esta regla lo son dos nobles (Antonio de Aragón y Francisco de Borja) que ocuparán plaza de consejero como retribución por los servicios que han prestado a la Corona sus progenitores.

La reina regente, durante la minoridad de su hijo Carlos II, resolvió un total de nueve consultas de la Cámara en las que proponía candidatos para vacantes del Consejo dé Órdenes. Aquélla, a instancias del presidente de éste Consejo y en contra de la opinión de la Cámara, nombrará en 1667 a un consejero supernumerario.

En 1684, Carlos II fijó en ocho las plazas de número. No obstante, creó varias plazas fuera de ese número. Aquél monarca empleará muy a menudo el

Hispania, LXIII/2, núm. 214 (2003) 657-744 
nombramiento mediante decreto - diecisiete veces-, sin apenas recurrir a la consulta de la Cámara, la cual en reiteradas ocasiones se quejaría de la utilización de este procedimiento extraordinario.

A los puestos de consejeros, durante el reinado del último de los Austrias, acceden algunas personas que no provienen de la magistratura sino de otras carreras, como la diplomática. 


\section{EXTRACTO DE CONSULTAS DEL CONSEJO DE LA CAMARA PARA PLAZAS DE CONSEJEROS DE ÓRDENES (1598-1700)}

\section{I.- REINADO DE FELIPE III}

\section{1}

Consulta de la Cámara, 25-IX-1599. Vacante por promoción de Francisco de Contreras al Consejo Real. Propuestos:

1) Ldo. Rui Díaz de Mendoza, oidor de la Audiencia de Valladolid. 2) Ldo. Egas Venegas Girón, oidor de la Audiencia de Valladolid. 3) Dr. Axpe, oidor de la Audiencia de Granada. 4) Luis de Padilla, oidor de la Audiencia de Granada.

Designado: Egas Venegas.

\section{2}

Consulta de la Cámara, 25-I-1600. Vacante por promoción de Álvaro de Benavides al Consejo Real. Propuestos:

a) El presidente y los licenciados Guardiola y Juan de Acuña «nombraron las dos personas que se siguen»:

1) Ldo. Egas Venegas, oidor de Valladolid. 2) Ldo. Luis de Padilla, oidor de Granada.

b) El presidente y los camaristas Alonso de Agreda y Juan de Acuña «nombraron las tres personas siguientes".

1) Ldo. Rui Díaz de Mendoza, oidor de Valladolid. 2) Ldo. Ochoa de Luyando, oidor de la Audiencia de Granada. 3) Ldo. García de Medrano, fiscal del Consejo de las Ordenes.

c) El Presidente y el Ldo. Juan de Acuña «nombran en tercer lugar»

- Al Dr. Axpe, oidor de la Chancillería de Granada.

Designado: García de Medrano.

\section{3}

Consulta de la Cámara, 31-III-1604. Dos plazas vacantes por promoción de Juan Alderete y de García de Medrano al Consejo Real. Propuestos:

Hispania, LXIII/2, núm. 214 (2003) 657-744 
1.- Ruis Díez de Mendoza, oidor de la Audiencia de Valladolid. 2.- Luis de Padilla, oidor de la Audiencia de Granada. 3.- Gerónimo de Medinilla, oidor de la Chancillería de Valladolid.

Designados los tres propuestos y también Diego López de Salcedo.

Consulta de la Cámara, 26 de junio de 1605. Propone para dos plazas vacantes en el Consejo de Ordenes por muerte de los licenciados Venegas y Díez de Mendoza.

a) Para la de Venegas:

1) Pedro de Vega, oidor de la Chancillería de Valladolid. 2) Alonso de Cabrera, oidor de la Chancillería de Valladolid. 3) Fernando Ramírez Fariña, oidor de la Chancillería de Granada.

b) Para la de Díez de Mendoza.

1) Sebastián de Villafañe, oidor de la Chancillería de Granada. 2) Ochoa de Urquizu, oidor de la Chancillería de Valladolid. 3) Juan de Escobar Chaves y Mendoza, oidor de la Chancillería de Granada.

Designados: Enrique Pimentel y Pedro de Vega.

Consulta de la Cámara, 14-II-1612. Plaza vacante en el Consejo de Órdenes por promoción de Jerónimo de Medinilla al Consejo Real. Sujetos propuestos:

1) Ldo. Mendo de Benavides, fiscal del Consejo de Órdenes. 2) Ldo. Alonso de Cabrera, oidor de la Chancillería de Valladolid. 3) Juan Gaitán de Ayala, oidor de la Chancillería de Valladolid.

Designado: Mendo de Benavides.

Consulta de la Cámara, 20-IX-1612. Plaza vacante en el Consejo de Órdenes por promoción de Diego López de Salcedo al Consejo Real. Sujetos propuestos:

1) Ldo. Alonso de Cabrera, fiscal del Consejo de Órdenes. 2) Ldo. Juan Gaitán de Ayala, oidor de la Chancillería de Valladolid. 3) Ldo. Gaspar de Vallejo, oidor de la Chancillería de Granada.

Designado: Alonso de Cabrera.

Hispania, LXIII/2, núm. 214 (2003) 657-744 
Consulta del Consejo de la Cámara, 8-VIII-1613. Plaza vacante en el Consejo de Órdenes por promoción de Enrique Pimentel al Consejo de la Inquisición. Propuestos:

1) Ldo. Juan Coello de Contreras, alcalde de Casa y Corte. 2) Ldo. Pedro de Guzmán, oidor de la Chancillería de Valladolid. 3) Dr. Pedro de Álava, fiscal del Consejo de Órdenes.

Designado. Pedro de Álava.

Consulta del Consejo de la Cámara, 8-VIII-1613. Plaza vacante en el Consejo de Órdenes por promoción de Pedro de Vega a la presidencia de la Chancillería de Valladolid. Propuestos:

1) Ldo. Juan Gaitán de Ayala, oidor de la Chancillería de Valladolid. 2) Sebastián de Villafañe, oidor de la Chancillería de Valladolid. 3) Dr. Mandojana, oidor de la Chancillería de Valladolid.

Designado: Juan Gaitán de Ayala.

Consulta del Consejo de la Cámara, 17-VI-1614. Plaza vacante por fallecimiento de Pedro de Álava. Propuestos:

1) Ldo. Juan Coello de Contreras, alcalde de Casa y Corte. 2) Ldo. Juan de Chaves y Mendoza, oidor de la Chancillería de Granada. 3) Ldo. Luis de Villavicencio, oidor de la Chancillería de Valladolid.

Designado: Juan Coello de Contreras.

Consulta del Consejo de la Cámara, 12-IV-1616. Dos plazas vacantes en el Consejo de Órdenes por promoción de Alonso de Cabrera y de Juan Gaitán de Ayala al Consejo Real y al de la Inquisición, respectivamente. Sujetos propuestos.

a) Para una:

1) Ldo. Sebastián de Villafañe, oidor de la Chancillería de Valladolid. 2) Dr. Pedro de Guzmán, oidor de la Chancillería de Valladolid. 3) Dr. Juan Jiménez de Oco, fiscal del Consejo de Órdenes. 
b) Para otra:

1) Ldo. Luis de Villavicencio, oidor de la Chancillería de Valladolid. 2) Ldo. Antonio de Castro y Andrade, oidor de la Chancillería de Valladolid. 3) Ldo. Fernando Pizarro de Orellana, oidor de la Chancillería de Granada.

Designados: Sebastián de Villafañe y Juan Jiménez de Oco. Además nombra el rey para otras dos plazas que han de vacar a Luis de Villavicencio y a Pedro de Guzmán.

\section{II.- REINADO DE FELIPE IV}

Consulta de la Cámara, 17-XII-1622. Plaza vacante en el Consejo de Órdenes por promoción de Pedro de Guzmán al Consejo Real. Propuestos:

a) El presidente «nombra»:

1) Ldo. Tomás Báñez de Rivera, oidor de la Chancillería de Granada. 2) Ldo. Miguel de Carvajal y Messía, oidor de la Chancillería de Valladolid. 3) Ldo. Juan de Villavicencio Ferrer, oidor de la Audiencia de Valladolid.

b) El camarista Luis de Salcedo propone:

1) Ldo. Gregorio de Tovar, oidor de la Chancillería de Valladolid. 2) Ldo. García de Haro, oidor de la Chancillería de Valladolid. 3) Ldo. Juan Queipo de Llano.

c) El camarista Melchor de Molina propone:

1) Al dicho García de Haro. 2) Ldo. Fernando Pizarro de Orellana, oidor de la Chancillería de Granada. 3) Al dicho Miguel de Carvajal y Messía.

d) El camarista Alonso de Cabrera propone:

1) Al dicho García de Haro. 2) Al dicho Miguel de Carvajal y Messía. 3) Ldo. Alonso de Montenegro y Sotomayor, oidor de la Chancillería de Granada.

e) El camarista Juan de Chaves propone:

1) Al dicho Fernando Pizarro de Orellana. 2) Al dicho Tomás Báñez de Rivera. 3) Al dicho Miguel de Carvajal y Messía.

Designado: García de Haro.

Consulta de la Cámara, 17-XII-1622. Plaza supernumeraria del Consejo de Órdenes, creada por decreto de 8 del mismo mes y año. Proponen:

a) El presidente:

1) Ldo. Juan Chumacero de Sotomayor, fiscal del Consejo de Órdenes. 2) Ldo. García de Haro, oidor de la Chancillería de Valladolid. 3) Ldo. Fernando Pizarro de Orellana, oidor de la Chancillería de Granada.

Hispania, LXIII/2, núm. 214 (2003) 657-744 
b) El camarista Luis de Salcedo:

1) Al dicho Chumacero. 2) Al dicho Pizarro. 3) Ldo. Luis Gudiel y Peralta, oidor de la Chancillería de Granada.

c) El camarista Melchor de Molina:

1) Al dicho Chumacero. 2) Ldo. Gregorio de Tovar, oidor de la Chancillería de Valladolid. 3) Al dicho Gudiel.

d) El camarista Alonso de Cabrera:

1) Al dicho Chumacero. 2) Al dicho Pizarro. 3) Ldo. García Portocarrero, oidor de la Chancillería de Valladolid.

e) El camarista Juan de Chaves y Mendoza:

1) Al dicho Chumacero. 2) Al dicho Pizarro. 3) Ldo. Tomás Báñez de Rivera, oidor de la Chancillería de Granada.

Designado: Juan Chumacero de Sotomayor.

Consulta de la Cámara, 27-II-1624. Plaza vacante en el Consejo de Órdenes por promoción de García de Haro al Consejo Real. Proponen:

a) El presidente:

1) Ldo. Tomás Báñez de Rivera, oidor de la Chancillería de Granada. 2) Ldo. Miguel de Carvajal y Messía, oidor de la Chancillería de Valladolid. 3) Ldo. Fernando Pizarro de Orellana, fiscal del Consejo de Órdenes.

b) El camarista Luis de Salcedo:

1) Al dicho Pizarro. 2) Ldo. Gaspar de Bracamonte Dávila, de la Cámara del infante Carlos. 3) Ldo. Luis Gudiel y Peralta, oidor de la Chancillería de Granada.

c) El camarista Melchor de Molina:

1) Al dicho Pizarro. 2) Ldo. Gregorio de Tovar, oidor de la Chancillería de Valladolid. 3) Al dicho Báñez.

d) El camarista Alonso de Cabrera:

1) Al dicho Pizarro. 2) Al dicho Carvajal. 3) Al dicho Gudiel.

e) El camarista Juan de Chaves:

1) Al dicho Pizarro. 2) Al dicho Báñez. 3) Ldo. Martín de Egues y Beaumont, oidor de la Chancillería de Valladolid.

Designado: Miguel de Carvajal y Messía. 
Consulta de la Cámara, 22-VII-1626. Dos plazas vacantes en el Consejo de Órdenes por promoción de Juan Coello de Contreras y Juan Chumacero de Sotomayor al Consejo, la de éste último supernumeraria. Propuestos.

a) Para la primera:

1) Ldo. Fernando Pizarro de Orellana, fiscal del Consejo de Órdenes. 2) Ldo. Tomás Báñez de Rivera, oidor de la Chancillería de Granada. 3) Ldo. Antonio de Camporredondo y Río, oidor de la Contaduría Mayor de Hacienda.

b) Para la otra:

1) Ldo. García Portocarrero, oidor de la Chancillería de Valladolid. 2) Ldo. Gregorio de Tovar, oidor de la Chancillería de Valladolid. 3) Dr. Mateo de Cerecedo y Alvear, oidor de la Chancillería de Valladolid.

Designados: Fernando Pizarro de Orellana y Gregorio de Tovar.

5

Consulta de la Cámara, 29-VIII-1630. Plaza del Consejo de Órdenes vacante por fallecimiento de Antonio de Castro. Propuestos:

1) Ldo. Antonio Briceño Ronquillo, fiscal del Consejo de Órdenes. 2) Ldo. Juan de Carvajal y Sande, «a quien hiço V. mag ${ }^{d}$. mrd. de plaça de oydor de Vallad. o Granada para quando llegase a estos Reys $^{\circ}$ de las Islas de Canaria, donde ha servido de Regente de aquella Aud ${ }^{a} »$. 3) Ldo. Juan de Mendoza, oidor de la Chancillería de Granada.

Designado: Antonio Briceño Ronquillo.

6

Consulta de la Cámara, 25-VIII-1631. Plaza vacante en el Consejo de Órdenes por jubilación de Gregorio de Tovar. Proponen:

a) El arzobispo gobernador:

1) Ldo. Juan de Mendoza, fiscal del Consejo de Órdenes. 2) Ldo. Juan Morales y Barnuevo, oidor de la Chancillería de Valladolid. 3) Ldo. Juan de Santelices y Guevara, oidor de la Chancillería de Granada.

b) El camarista Melchor de Molina:

1) Al dicho Mendoza. 2) Al dicho Morales 3) Ldo. Diego de Cevallos y de la Vega, regente del Consejo de Navarra.

c) El camarista Fernando Ramírez Fariña:

1) Ldo. Cristóbal de Moscoso y Córdoba, oidor de la Chancillería de Valladolid. 2) $\mathrm{Al}$ dicho Cevallos. 3) $\mathrm{Al}$ dicho Mendoza.

Hispania, LXIII/2, núm. 214 (2003) 657-744 
d) El camarista Juan de Chaves y Mendoza:

1) Al dicho Mendoza. 2) Ldo. Juan del Castillo Sotomayor, oidor del Consejo y Contaduría Mayor de Hacienda. 3) Al dicho Santelices.

e) El camarista Diego de Corral y Arellano:

1) Al dicho Cevallos. 2) Al dicho Mendoza. 3) Al dicho Moscoso.

f) El camarista Francisco de Tejada y Mendoza:

1) Al dicho Cevallos. 2) Al dicho Moscoso. 3) Ldo. Tomás Báñez de Rivera, oidor de la Chancillería de Granada.

g) El camarista Juan Chumacero y Carrillo:

1) Al dicho Moscoso. 2) Al dicho Báñez. 3) Al dicho Cevallos.

Designado: Antonio de Luna, fiscal del Consejo de Guerra. No propuesto.

\section{7}

Consulta de la Cámara, 20-III-1632. Plaza vacante en el Consejo de Órdenes por jubilación de Juan de Oco. Proponen:

a) El arzobispo gobernador:

1) Ldo. Juan de Mendoza, fiscal del Consejo de Órdenes. 2) Ldo. Manuel de Guzmán, oidor de la Chancillería de Valladolid. 3) Ldo. Juan de Morales y Barnuevo, oidor de la Chancillería de Valladolid.

b) El camarista Melchor de Molina:

1) Al dicho Mendoza. 2) Al dicho Morales. 3) Ldo. Juan de Santelices y Guevara, oidor de la Chancillería de Granada.

c) El camarista Fernando Remírez Fariña:

1) Ldo. Cristóbal Moscoso y Córdoba, oidor de la Chancillería de Valladolid. 2) Ldo. Diego de Cevallos y de la Vega, regente del Consejo de Navarra. 3) Ldo. Diego Rodríguez Baltodano, oidor de la Chancillería de Valladolid.

d) El camarista Juan de Chaves y Mendoza:

1) Al dicho Mendoza. 2) Al dicho Guzmán. 3) Al dicho Santelices.

e) El camarista Francisco de Tejada y Mendoza:

1) $\mathrm{Al}$ dicho Moscoso. 2) Al dicho Cevallos. 3) Ldo. Tomás Báñez de Rivera, oidor de la Chancillería de Granada.

f) El camarista conde de Castrillo:

1) $\mathrm{Al}$ dicho Moscoso. 2) $\mathrm{Al}$ dicho Cevallos. 3) $\mathrm{Al}$ dicho Báñez

g) El camarista Juan Chumacero y Carrillo:

1) Al dicho Moscoso. 2) Al dicho Báñez. 3) Al dicho Baltodano.

Designado: Manuel de Guzmán. Asimismo el rey nombra para una plaza supernumeraria que acaba de vacar por fallecimiento de Juan Serrano Zapata a Juan de Mendoza.

Hispania, LXIII/2, núm. 214 (2003) 657-744 
Consulta de la Cámara, 4-IX-1632. Plaza vacante en el Consejo de Órdenes por promoción de Miguel de Carvajal al Consejero Real. Proponen:

a) El arzobispo de Granada, gobernador del Consejo:

1) Ldo. Diego de Cevallos y de la Vega, regente del Consejo de Navarra. 2) Ldo. Juan de Morales y Barnuevo, oidor de la Chancillería de Valladolid. 3) Cristóbal de Moscoso y Córdoba, oidor de la Chancillería de Valladolid.

b) El camarista Fernando Remírez Fariña:

1) Al dicho Cevallos. 2) Al dicho Moscoso. 3) Ldo. Diego Rodríguez Baltodano, oidor de la Chancillería de Valladolid.

c) El camarista Juan de Chaves y Mendoza:

1) Al dicho Cevallos. 2) $\mathrm{Al}$ dicho Morales. 3) Al dicho Moscoso.

d) El camarista Francisco de Tejada y Mendoza:

1) $\mathrm{Al}$ dicho Cevallos. 2) $\mathrm{Al}$ dicho Morales. 3) Al dicho Moscoso.

e) El camarista conde de Castrillo:

1) Al dicho Cevallos. 2) $\mathrm{Al}$ dicho Moscoso. 3) Ldo. Pedro de Alarcón de Ocón, alcalde del crimen de la Chancillería de Valladolid.

f) El camarista José González:

1) Al dicho Cevallos. 2) Al dicho Morales. 3) Al dicho Moscoso.

Designado: Diego de Cevallos y de la Vega.

9

Consulta de la Cámara, 19-I-1633. Plaza vacante en el Consejo de Órdenes por ascenso de Fernando Pizarro. Proponen los miembros de la Cámara lo siguiente:

a) El arzobispo de Granada, gobernador del Consejo:

1) Ldo. Juan de Morales y Barnuevo, oidor de la Chancillería de Valladolid. 2) Ldo. Diego de Riaño y Gamboa, oidor de la Chancillería de Granada. 3) Ldo. Pedro Ordóñez de la Real, oidor de la Chancillería de Granada.

b) El camarista Juan de Chaves y Mendoza:

1) Ldo. Tomás Báñez de Rivera, oidor de la Chancillería de Granada. 2) Al dicho Riaño. 3) Ldo. Juan de Salas y Valdés, oidor de la Chancillería de Valladolid.

c) El camarista Francisco de Tejada:

1) Al dicho Báñez. 2) Ldo. Álvaro de Oca y Zúñiga, sin destino y ex oidor de la Chancillería de Granada. 3) Ldo. Cristóbal de Moscoso y Córdoba, oidor de la Chancillería de Valladolid.

Hispania, LXIII/2, núm. 214 (2003) 657-744 
d) El camarista conde de Castrillo:

1) Al dicho Moscoso. 2) Al dicho Báñez. 3) Ldo. Pedro de Alarcón, alcalde del crimen de la Chancillería de Valladolid.

e) El camarista Juan de Chumacero.

1) Al dicho Moscoso. 2) Al dicho de Oca. 3) Al dicho Báñez.

f) El camarista José González:

1) Al dicho Báñez. 2) Al dicho de Oca. 3) Al dicho Salas.

Designado: Juan de Zambrana, fiscal del Consejo de Órdenes y. no consultado.

10

Consulta de la Cámara, 12-III-1635. Plaza vacante por promoción de Antonio Briceño Ronquillo a Gran Chanciller de Milán. Con votos secretos.

Designado: Juan Girón, fiscal del Consejo de Guerra.

\section{1}

Consulta de la Cámara, 8-X-1636. Con votos secretos.

Designado: Dr. Álvaro de Oca, regente del Consejo de Navarra.

12

Consulta de la Cámara, 15-X-1636. Propone al rey que se conceda título de consejero de Órdenes a Diego Rodríguez Baltodano, fiscal del mismo y que ya tenía voto.

Resolución real:. «déssele el título».

13

Consulta de la Cámara, 22-X-1638. Plaza vacante en el Consejo de Órdenes por promoción de Sebastián Zambrana de Villalobos al Consejo Real. Por votos secretos.

Designado: Claudio Pimentel, fiscal del Consejo de Órdenes.

14

Consulta de la Cámara, 8-X-1642. Propone a Pedro de Alarcón Ocón, oidor de la Chancillería de Valladolid y corregidor de Asturias, para una plaza supernumeraria del Consejo de Órdenes.

Resolución real: «Está bien».

Hispania, LXIII/2, núm. 214 (2003) 657-744 
Consulta del Consejo de Indias, 1646. "Agustín del Hierro y Antonio de Benavides; Plazas del Cons $^{\circ}$ de Órdenes, en consulta del Cons $^{\circ}$ de Yndias del año de 1646».

16

Consulta de la Cámara, 31-VIII-1648. Plaza vacante en el Consejo de Órdenes por promoción de Agustín del Yerro a fiscal del Consejo Real. Propuestos:

1) Ldo. Diego Zapata, fiscal del Consejo de Órdenes. 2) Ldo. Gregorio de Contreras.

3) Ldo. Juan Arce y Otalora.

Designado: Diego Zapata.

17

Consulta de la Cámara, 9-VI-1649. Propone a Alonso de la Torre Ibernia, oidor de la Chancillería de Valladolid y agente en Roma, para una plaza supernumeraria del Consejo de Órdenes.

Resolución real: «Está bien».

18

Consulta de la Cámara, 14-IX-1650. Plaza supernumeraria vacante por fallecimiento de Marcos Tamariz de la Escalera. Propuestos:

1) Ldo. Pedro de Munibe. 2) Ldo. José de Pueyo Muñoz. 3) Ldo. Mateo de Villamarín.

Designado. Mateo de Villamarín.

\section{9}

Consulta de la Cámara, 26-IV-1651. Provisión de dos plazas en el Consejo de Órdenes. Propuestos:

a) Para la primera:

1) Ldo. Pedro de Munibe. 2) Ldo. Gregorio Antonio de Chaves. 3) Ldo. José del Pueyo.

b) Para la segunda:

1) Ldo. Pedro de la Cantera Salazar. 2) Ldo. Juan de Cerecedo. 3) Ldo. Gregorio González de Contreras.

Designados: Pedro de Munibe y Gregorio de Chaves.

Hispania, LXIII/2, núm. 214 (2003) 657-744 
Consulta de la Cámara, 8-IV-1652. Plaza vacante en el Consejo de Órdenes, por promoción de Diego Zapata a Gran Chanciller de Milán. Propuestos:

1) Ldo. José del Pueyo. 2) Ldo. Juan de Cerecedo Alvear. 3) Ldo. Bernabé de Andrade.

Designado: Juan de Arce y Otalora, regente del Consejo de Navarra y no consultado.

21

Consulta de la Cámara, 27-III-1653. Provisión de dos plazas del Consejo de Órdenes, una vacante por promoción de Pedro Munibe al Consejo Real y otra supernumeraria. Propuestos:

a) Para la primera:

1) Ldo. Francisco de Vergara. 2) Ldo. Miguel de Luna Arellano. 3) Ldo. Antonio Riaño y Salamanca.

b) Para la otra:

1) Ldo. Juan de Estrada Manrique. 2) Ldo. Francisco Valderrama y Haro. 3) Ldo. Diego Arredondo Alvarado.

Designados: Francisco de Vergara y Juan de Estrada.

22

Consulta de la Cámara, 24-III-1654. Plaza vacante en el Consejo por fallecimiento de Gregorio de Chaves. Propuestos:

1) Ldo. Bernabé de Andrade y Funes. 2) Ldo. Francisco Guillén del Águila. 3) Ldo. Miguel de Luna y Arellano.

Designado: Miguel de Luna y Arellano, fiscal del Consejo de Órdenes.

23

Consulta de la Cámara, 31-V-1656. Plaza supernumeraria en el Consejo de Órdenes. Propuestos:

1) Ldo. Antonio de Riaño y Salamanca. 2) Ldo. Bernabé de Andrade y Funes. 3) Ldo. Diego de Arredondo Alvarado.

Designado: Antonio de Riaño. 
Consulta de la Cámara, 3-I-1657. Plaza vacante en el Consejo de Órdenes por promoción de Juan de Arce Otalora al Supremo Consejo. Propuestos:

1) Bernabé de Andrade. 2) Atanasio Giménez de Arellano. 3) Fernando Dávila.

Designado: Bernabé de Andrade.

\section{5}

Consulta de la Cámara, 8-I-1657. Plaza vacante en el Consejo de Órdenes por promoción de Francisco de Vergara a la fiscalía del Consejo Real. Propuestos:

1) Ldo. Fernando Arce Dávila. 2) Ldo. Atanasio Giménez de Arellano. 3) Juan Antonio de Molina Medrano.

Designado: Fernando de Arce.

Consulta de la Cámara, 24-I-1659. Provisión de dos plazas vacantes en el Consejo de Órdenes, una por promoción de Gerónimo Mascareñas al Consejo de Portugal y otra por fallecimiento de Bernabé de Andrade. Propuestos:

a) Para la primera:

1) Ldo. Juan Ramírez de Arellano. 2) Ldo. Gabriel de Chaves Sotomayor. 3) Fernando Queipo de Llano.

b) Para la otra:

1) Ldo. Juan Antonio de Molina y Medrano. 2) Ldo. Baltasar de la Cueva. 3) Ldo. Francisco Roco de Córdoba.

Designados: Juan de Arellano y Juan Golfín.

27

Consulta de la Cámara, 11-VIII-1659. Plaza vacante en el Consejo de Órdenes por promoción de Miguel de Luna y Arellano al Consejo de Indias. Propuestos:

1) Ldo. Baltasar de la Cueva. 2) Ldo. Gabriel de Chaves. 3) Ldo. Juan Antonio de Molina.

Designado: Baltasar de la Cueva.

Consulta de la Cámara, 26-X-1660. Plaza vacante en el Consejo de Órdenes por promoción de Juan Ramírez de Arellano al Consejo de Indias. Propuestos:

Hispania, LXIII/2, núm. 214 (2003) 657-744 
1) Ldo. Gabriel de Chaves. 2) Ldo. Francisco Paniagua. 3) Ldo. Gerónimo Morquecho.

Designado: Gabriel de Chaves.

\section{9}

Consulta de la Cámara, 19-I-1661. Plaza vacante en el Consejo de Órdenes por fallecimiento de Juan de Estrada. Propuestos:

1) Ldo. Fernando Queipo de Llano. 2) Ldo. Juan de Córdoba. 3) Ldo. Juan de Navarrete.

Resolución: no la provee el rey.

\section{0}

Consulta de la Cámara, 10-VII-1662. Provisión de una plaza en el Consejo de Órdenes además de las seis de número. Propuestos:

1) Ldo. Francisco Paniagua. 2) Ldo. Jerónimo Morquecho. 3) Ldo. Juan Navarrete.

Designado: Jerónimo Morquecho.

\section{1}

Consulta de la Cámara, 28-I-1664. Plaza supernumeraria vacante en el Consejo de Órdenes por promoción de Juan Golfín de Carvajal al Consejo Real. Propuestos:

1) Ldo. Francisco de Medrano. 2) Ldo. Gerónimo de Prado. 3) Ldo. Fernando Queipo de Valdés.

Designado: Francisco de Medrano.

\section{2}

Consulta de la Cámara, 26-III-1664. Plaza supernumeraria creada en el Consejo de Órdenes. Propuestos:

1) Ldo. Juan Bautista Navarrete. 2) Ldo. Jerónimo de Prado. 3) Ldo. Pedro de Ulloa Golfín.

Designado: Jerónimo de Prado.

33

Consulta de la Cámara, 15-IX-1664. Plaza supernumeraria del Consejo de Órdenes. Propuestos:

Hispania, LXIII/2, núm. 214 (2003) 657-744 
1) Ldo. Gonzalo de Córdoba. 2) Ldo. Juan Pimentel. 3) Ldo. Fernando Queipo.

Designado: Gonzalo de Córdoba.

Consulta de la Cámara, 5-VII-1665. Plaza vacante supernumeraria por promoción de Baltasar de la Cueva al Consejo de Indias. Propuestos:

1) Ldo. Antonio de Urrutia. 2) Ldo. Pedro de Ulloa. 3) Ldo. Pedro Ronquillo.

Designado: Antonio de Urrutia.

\section{III.- REINADO DE CARLOS II}

1

Consulta de la Cámara, 4-VII-1667. Es partidaria de que se cree una plaza supernumeraria del Consejo de Órdenes para Fernando Queipo, fiscal del mismo Consejo.

Resolución: se nombra a Fernando Queipo.

2

Consulta de la Cámara, 4-II-1669. Plaza supernumeraria del Consejo de Órdenes. Propuestos:

1) Ldo. José Ponce de León. 2) Ldo. Antonio de Sevil Santelices. 3) Ldo. Pedro Gil de Alfaro.

Designado. José Ponce de León.

3

Consulta de la Cámara, 5-I-1671. Plaza vacante en el Consejo por promoción de Antonio de Riaño al Consejo Real. Propuestos:

1) Jerónimo Ramos del Manzano. 2) Sancho de Villegas. 3) Gabriel Menéndez.

Designado: Jerónimo Ramos del Manzano.

4

Consulta de la Cámara, 12-I-1671: Plaza vacante en el Consejo de Órdenes por promoción de Gonzalo de Córdoba al Consejo Real. Propuestos:

Hispania, LXIII/2, núm. 214 (2003) 657-744 
1) Gabriel Menéndez. 2) Pedro de Ulloa Golfín. 3) Juan Ordóñez.

Designado: Gabriel Menéndez.

Consulta de la Cámara, 16-XI-1671. Plaza vacante en el Consejo de Órdenes por promoción de José Ponce al Consejo de indias.

1) Pedro de Ulloa Golfín. 2) Rodrigo Portocarrero. 3) Juan Ordóñez.

Designado: Pedro de Ulloa Golfín, fiscal del Consejo de Órdenes.

Consulta de la Cámara, 27-I-1672. Provisión de dos plazas vacantes en el Consejo de Órdenes por promociön de Fernando de Arce y Gerónimo Morquecho. Propuestos:

a) Para una:

1) Rodrigo Portocarrero. 2) Carlos de Villamayor. 3) Francisco Godínez de Paz.

b) Para la otra:

1) Juan Ordóñez. 2) Pedro de Gamarra. 3) José de Salamanca.

Designado: Juan de Ordóñez, fiscal del Consejo de Guerra y para la otra había nombrado al rey previamente sin consulta de la Cámara a Rodrigo Portocarrero.

\section{7}

Consulta de la Cámara, 4-V-1672. Plaza vacante en el Consejo de Órdenes por promoción de Jerónimo de Prado al Consejo Real. Propuestos:

1) Carlos de Villamayor. 2) Francisco Godínez de Paz. 3) Pedro de Gamarra Urquizu.

Designado: Carlos de Villamayor.

Consulta de la Cámara, 17-V-1673. Plaza vacante en el Consejo de Órdenes por fallecimiento de Juan Ordóñez. Propuestos:

1) Cristóbal de Corral Ipiñarrieta. 2) Francisco Godínez de Paz. 3) Pedro de Gamarra Urquizu.

Designado: Cristóbal de Corral Ipiñarrieta.

Hispania, LXIII/2, núm. 214 (2003) 657-744 
Consulta de la Cámara, 27-XI-1673. Plaza vacante en el Consejo de Órdenes por promoción de Pedro de Ulloa. Propuestos:

1) Francisco. Godínez de Paz. 2) Luis de Salcedo. 3) Pedro de Gamarra Urquizu.

Designado: Luis de Salcedo.

\section{0}

Consulta de la Cámara, 4-XII-1673. Plaza vacante en el Consejo de Órdenes. Propuestos:

1) Pedro Sarmiento y Toledo. 2) Pedro de Gamarra y Urquizu. 3) Fernando de Moscoso Ossorio.

Designado. Pedro Sarmiento y Toledo.

11

Consulta de la Cámara, 29-XII-1677. Plaza en el Consejo de Órdenes. Propuestos:

1) Alonso Escudero, seis votos (unanimidad). 2) Luis de Cañas, tres votos. 3) Alonso de Aguilar, cuatro votos.

Designado. Alonso Escudero.

12

Consulta de la Cámara, 18-I-1678. Apoya la pretensión de Francisco de Moscoso Osorio, arcediano de Madrid y Sumiller de Cortina del rey, en solicitud de una plaza supernumeraria del Consejo de Órdenes.

Resolución: es designado Moscoso consejero de Órdenes supernumerario, «sin gages ni salario».

13

Consulta de la Cámara, 18-V-1679. Apoya la pretensión de Andrés de Riaño, ex consejero de Hacienda, en la que solicita una plaza supernumeraria del Consejo de Órdenes.

Resolución: es designado Riaño consejero supernumerario de Órdenes.

14

Consulta de la Cámara, 6-XI-1679. Plaza del Consejo de Órdenes. Propuestos:

Hispania, LXIII/2, núm. 214 (2003) 657-744 
1) Alonso de Aguilar, tres votos. 2) Luis de Cañas, cuatro votos. 3) Luis Barahona, cuatro votos.

Designado: Alonso de Aguilar.

Consulta de la Cámara, 2-X-1680. Plaza vacante por promoción de Rodrigo Portocarrero al Consejo Real. Propuestos:

1) Martín Pimienta, cuatro votos. 2) José Portocarrero, cuatro votos. 3) Bernabé de Otalora, cuatro votos.

Designado: Isidro de Camargo, no propuesto.

16

Consulta de la Cámara, 2-V-1695. Propuestos para una plaza del Consejo de Órdenes:

1) Juan Ramírez Baquedano, por unanimidad. 2) Francisco Colón de Larreategui, por unanimidad. 3) Ignacio López de Zárate, cinco votos.

Designado: Juan Ramírez Baquedano

Consulta de la Cámara, 3-VI-1697. Propuestos para una plaza del Consejo de Órdenes:

1) Francisco Colón de Larreategui, tres votos. 2) Pedro Queipo, por unanimidad. 3) Mateo Ibáñez de Mendoza, cuatro votos

Designado: Pedro Queipo

18

Consulta de la Cámara, 3-VI-1697. Plaza una plaza supernumeraria del Consejo de Órdenes, se proponen:

1) Juan de Chalar, tres votos. 2) García Pérez de Araziel, por unanimidad. 3) Francisco de Cevallos, por unanimidad.

Designado: Juan de Chalar

19

Consulta de la Cámara, 9-XII-1697. Para una plaza supernumeraria del Consejo de Órdenes, se proponen:

Hispania, LXIII/2, núm. 214 (2003) 657-744 
1) Cristóbal de Chaves, tres votos. 2) Diego Hermoso Romero, tres votos. 3) Bernardino de Cuéllar y Medrano, por unanimidad.

Designado: Cristóbal de Chaves.

Consulta de la Cámara, 9-XII-1697. Plaza vacante en el Consejo de Órdenes por haber sido designado Queipo presidente de la Chancillería de Valladolid. Propuestos:

1) Francisco de Cevallos El Cavallero, por unanimidad. 2) Mateo Ibáñez de Mendoza, tres votos. 3) Conde de Lences, tres votos.

Designado: Francisco de Cevallos El Cavallero.

21

Consulta de la Cámara, 7-VII-1700. Plaza vacante por promoción de Juan Ramírez de Baquedano, marqués de Andía, a plaza del Consejo Real. Propuestos:

1) Nuño Ibáñez de Mendoza, por unanimidad. 2) José Bolero, tres votos. 3) Francisco de Toro Muñoz, por unanimidad.

Designado: Nuño de Mendoza

Fuente: AHN, Consejos, leg. 51.708 y Estado, leg. 6406. 


\section{APUNTES BIOGRÁFICOS DE LOS CONSEJEROS DE ÓRDENES (1598-1700)*}

\section{I.- REINADO DE FELIPE III}

\section{1.- Álvaro de BENAVIDES}

- Oidor de la Chancillería de Valladolid, 20-IV-1592

- Consejero de Órdenes, Madrid, 16-I-1599. Juramento: Madrid, 21-I-1599. Ocupa la plaza que deja vacante Gaspar de Bonifaz.

- Consejero real supernumerario, Madrid, 7-II-1600. Comienza el título «Por quanto por la falta de salud con que se halla el licençiado don Luis de Mercado del nuestro Consejo conviene probeher otra plaza del dicho Consejo que sea supernumeraria entretanto que hacemos merced al dicho don Luis». Toma de posesión: Madrid, 9-II-1600. Anualmente percibió unos emolumentos de 500.000 maravedís.

- Consejero de la Cámara, Valladolid, 8-IX-1602. Vacante por promoción de Juan de Acuña a presidente del Consejo de Hacienda. Salario anual: 50.000 maravedís.

\section{2.- Antonio de PEDROSA}

- Comendador de Almagro.

- Alcalde Mayor del Reino de Galicia.

- Oidor de la Chancillería de Valladolid, 7-VIII-1593.

- Consejero de Órdenes. Título: Barcelona, 14-VI-1599. Juramento: Madrid, 23VI-1599. Plaza vacante por promoción de Juan de Ocón a consejero de Indias.

- Jubilación, con retención del título y salario de la dicha plaza del Consejo de Órdenes y de la casa de aposento (Cédula, San Lorenzo, 20-VIII-1616).

- Falleció, 17-V1625.

\section{3.- Egas VENEGAS GIRÓN}

- Colegial del Colegio de Cuenca en Salamanca.

- Alcalde del Crimen de la Chancillería de Valladolid, 1589.

- Oidor de la Chancillería de Valladolid, 18-XII-1598.

- Oidor del Consejo de Órdenes. Toma de posesión: 4-VIII-1600.

- Falleció: Valladolid, 10-VI-1605.

- Mujer: Ana de Zúñiga.

* Las fechas que aparecen, salvo que se indique otra cosa en contrario, son las del título de nombramiento. De algunos de los consejeros de Órdenes que fueron promocionados al Consejo de Castilla he optado por no incluir su carrera posterior, la que se puede seguir a través de la obra de Fayard, citada al final. 


\section{4.- García de MEDRANO}

- Colegial de San Bartolomé.

- Alcalde de Granada (1584).

- Procurador de Cortes por Soria.

- Fiscal del Consejo de Ordenes. Toma de posesión, 4-V-1599.

- Oidor del Consejo de Órdenes. Toma de posesión, 3-III-1600.

- Consejero Real supernumerario, 21-II-1604. Juramento: 16-VI-1604.

\section{5.- Ruy DÍAZ DE MENDOZA}

- Colegial del Colegio del Arzobispo de Salamanca.

- Oidor de la Chancillería de Granada, 25-IX-1589.

- Oidor de la Chancillería de Valladolid, 13-III-1599

- Consejero de Órdenes, 28-VIII-1604. En lugar de Juan de Alderete, promovido al Consejo de Castilla. Juramento: Valladolid, 6-IX-1604.

- Falleció: 5-V-1605.

\section{6.- Luis de PADILLA MENESES}

- Dr. en ambos Derechos.

- Colegial de Bolonia.

- Alcalde mayor de Galicia.

- Oidor de la Chancillería de Granada, 1594.

- Consejero de Órdenes, Valladolid, 12-XI-1604. Juramento: Valladolid, 15-XI1604. Plaza vacante por fallecimiento de Gaspar Bonifaz.

- Del Consejo Real, San Lorenzo, 16-V-1609. Juramento: Madrid, 18-V-1609. Sucedió a García de Medrano.

— Consejero de la Cámara, 2-I-1612. Sustituyó a Núñez de Bohórquez, fallecido.

\section{7.- Gerónimo de MEDINILLA}

- Oidor de la Chancillería de Valladolid, 13-VII-1593.

- Consejero de Órdenes, 18-VIII-1604. Vacante por promoción de García de Medrano al Consejo de Castilla. Juramento: Valladolid, 6-IX-1604.

- Consejero Real, 2-II-1612. Juramento: Madrid, 4-II-1612.

- Viuda: Petronila de Velasco. Por cédula, 6-II-1630, se concede 3.000 ducados «por una vez en vacantes de plazas del número de nuestra Corte».

- Hijos: Gerónimo Antonio de Medinilla, corregidor de Córdoba y Pedro de Velasco y Medinilla, oidor de la Chancillería de Valladolid.

\section{8.- Diego LÓPEZ DE SALCEDO}

- Colegial del Colegio de Santa Cruz de Valladolid.

- Juez Mayor de Vizcaya.

- Consejero de Órdenes, 1604.

— Consejero de Castilla, 1612.

Hispania, LXIII/2, núm. 214 (2003) 657-744 


\section{9.- Enrique PIMENTEL ZÚÑIGA}

- Consejero de Órdenes, 29-III-1606. Vacante por fallecimiento de Rui Díaz de Mendoza. Tomó posesión: Madrid, 6-X-1606.

- Consejero de la Inquisición, 1613.

- Obispo de Valladolid, 1619.

- Obispo de Cuenca, 1623.

\section{0.- Pedro de VEGA Y SALAZAR}

- Colegial del Colegio de San Bartolomé en Salamanca.

- Inquisidor de los Tribunales de Valladolid y de Córdoba.

- Oidor de la Chancillería de Valladolid, 10-VII-1601.

- Consejero de Órdenes, 22-II-1608. Vacante por fallecimiento de Egas Venegas. Posesión: 14-III-1608.

- Presidente de la Chancillería de Valladolid, 10-VIII-1613.

- Fallecimiento: 16-VII-1614.

\section{1.-Juan SERRANO ZAPATA}

- Fiscal del Consejo de Órdenes, 2-IX-1604. Juramento: Valladolid, 9-IX-1604.

- Consejero de Órdenes, 22-VIII-1609. En lugar de Luis de Padilla, promovido al Consejo Real. Juramento: Madrid, 31-VIII-1609.

- Embajador de Génóva, 1629.

\section{2.- Mendo de BENAVIDES}

- Nacido en Santisteban del Puerto (Jaén), 1569.

- Colegial del Colegio de Santa Cruz..

- Catedrático de Leyes en la Universidad de Valladolid.

- Oidor de la Chancillería de Valladolid, 17-IX-1604.

- Fiscal del Consejo de Órdenes, 4-XI-1610. Juramento. Madrid, 9-XI-1610.

- Consejero de Órdenes, 1-IV-1612. Vacante por promoción de Gerónimo de Medinilla al Consejo Real. Juramento: Madrid, 2-IV-1612.

- Consejero de la Inquisición, 1617.

- Presidente de la Chancillería de Granada, 23-VII-1624.

- Obispo de Segovia, consagrado el 18-VII-1633.

- Obispo de Cartagena, consagrado el 19-XI-1640.

- Fallecimiento: 17-X-1644.

\section{3.- Alonso de CABRERA}

- Colegial del colegio del azrobispo en Salamanca.

- Oidor de la Chancillería de Valladolid.

- Fiscal del Consejo de Órdenes, 19-V-1612. Vacante por promoción de Mendo de Benavides a consejero de Órdenes. Juramento. Madrid, 27-V-1612. 
- Consejero de Órdenes, 6-XII-1612. Vacante por promoción de Diego López de Salcedo al Consejo Real. Juramento: Madrid, 7-XII-1612.

— Oidor supernumerario del Consejo, 9-IV-1616. Juramento: Madrid, 11-IV-1616.

\section{4.- Pedro de ÁLAVA}

- Colegial en Oñate y en el colegio de Santa Cruz de Valladolid.

- Rector de la Universidad de Valladolid.

- Catedrático de Código y de Digesto Viejo.

- Catedrático sustituto de Prima de Leyes y de Decreto.

- Juez Mayor de Vizcaya y Alcalde de Hijosdalgo sustituto.

- Oidor de la Chancillería de Valladolid, 20-IX-1608.

- Fiscal del Consejo de Órdenes, 5-III-1613. Plaza vacante por promoción de Alonso de Cabrera a consejero de Órdenes. Juramento: Madrid, 15-IV-1613.

- Oidor del Consejo de Órdenes, 7-IX-1613. Plaza vacante por promoción de Enrique Pimentel al Consejo de la Inquisición. Juramento: Madrid, 9-IX-1613.

\section{5.- Juan GAITÁN DE AYALA}

- Colegial del Colegio del Arzobispo de Salamanca.

- Inquisidor de Cuenca y de Granada.

- Oidor de la Chancillería de Valladolid, 2-XII-1604.

- Consejero de las Órdenes, 2-XI-1613. Plaza vacante por promoción de Pedro de Vega a presidente de la Chancillería de Valladolid.

- Consejero de Inquisición, 1616.

\section{6.-Juan de COELLO DE CONTRERAS}

- Alcalde supernumerario de Casa y Corte, 24-V-1611. Juramento: Madrid, 28-V1611.

- Consejero de Órdenes, 26-VIII-1614. Vacante por fallecimiento de Pedro de Álava. Juramento: Madrid, 28-VIII-1614.

- Consejero supernumerario del Real, 7-V-1626. Juramento: Madrid, 11-V-1626.

- Cédula, 2-VI-1629, el rey hace merced a Juana de Vega, viuda de Coello, de 3.000 ducados.

\section{7.- Sebastián de VILLAFAÑ $E$}

- Hijo del Dr. Villafañe, consejero de Castilla y camarista.

- Ldo. en Cánones por la Universidad de Salamanca.

- Dr. por la Universidad de Valladolid.

- Colegial del Colegio de Santa Cruz de Valladolid.

- Catedrático de Sexto en propiedad en la Universidad de Valladolid.

- Oidor de la Chancillería de Granada, 1602.

- Oidor de la Chancillería de Valladolid, 21-VIII-1609.

Hispania, LXIII/2, núm. 214 (2003) 657-744 
- Designado por el rey en 1610 fiscal de Indias, renunció.

- Oidor del Consejo de Órdenes, 1616. Muere en Valladolid el 10 de mayo de ese año sin haber tomado posesión.

Falleció, 2-VIII-1632.

\section{8.- Juan JIMÉNEZ DE OCÓN}

- Oidor de Comptos.

- Alcalde de la Corte Mayor.

- Fiscal del Consejo de Órdenes, 31-I-1614

Real.

- Consejero de Órdenes, 19-IV-1616. Vacante por promoción de Cabrera al Consejo

\section{9.- Luis de VILLAVICENCIO}

- Oidor de la Chancillería de Valladolid; 2-XII-1602.

- Oidor del Consejo de Órdenes, 24-IX-1616. Plaza vacante por jubilación de Antonio de Pedrosa. Juramento: 24-X-1616.

- Consejero de Castilla, 6-V-1628.

\section{0.- Pedro de GUZMÁN}

- Oidor de la Chancillería de Valladolid, 21-VIII-1609.

- Consejero supernumerario de Órdenes, 12-I-1617. Vacante por promoción de Juan Gaitán de Ayala al Consejo de la Inquisición. Juramento: Madrid, 13-I-1617. 1622 .

- Consejero supernumerario del Real, 11-XII-1622. Juramento: Madrid, 15-XII-

\section{1.- Antonio de CASTRO Y ANDRADE}

- Colegial y Rector del Colegio de San Bartolomé en Salamanca.

- Del Colegio de pasantes de Santiago de Salamanca.

- Alcalde de Hijosdalgo de la Chancillería de Granada, 21-VIII-1609.

- Oidor de la Chancillería de Valladolid, 14-II-1614.

- Fiscal del Consejo de Órdenes, 28-II-1617. Vacante por promoción de Juan Jiménez de Ocón al mismo Consejo. Juramento: Madrid, 2-III-1617.

- Consejero de Órdenes, 23-IX-1617. Vacante por promoción de Mendo de Benavides al Consejo de la Inquisición. Juramento: Madrid, 3-X-1617.

- Falleció, 19-VIII-1630. 


\section{1.- REINADO DE FELIPE IV}

\section{1.- Juan CHUMACERO DE SOTOMAYOR Y CARRILLO, CONDE DE GUARO}

- Oidor de la Chancillería de Granada, 9-VIII-1614.

- Fiscal del Consejo de Órdenes, 8-III-1621. Vacante por promoción de Pedro de Vivanco Villagómez a consejero de Indias. Juramento: Madrid, 11-III-1621.

- Consejero supernumerario de Órdenes, 23-XII-1622.

- Consejero supernumerario del Real, 7-V-1626. Juramento: Madrid, 11-V-1626.

- Fiscal del Consejo Real, 3-VI-1626. Vacante por promoción de Francisco de Alarcón a consejero del mismo. Juramento: Madrid, 11-V-1626.

- Presidente del Consejo Real, a partir de 16 de marzo de 1643, en lugar de Diego Castrejón, gobernador, elegido obispo de Tarazona.

\section{2.- Garcia de HARO y AVELLANEDA, CONDE DE CASTRILLO}

- Oidor de la Chancillería de Valladolid, 19-III-1619.

- Consejero de Órdenes, 13-V-1623. Vacante por promoción de Pedro de Guzmán al Consejo Real. Juramento: Madrid, 24-V-1623.

- Consejero supernumerario del Real, 17-II-1624. Juramento: Madrid, 26-II-1624.

- Camarista, 7-IV-1625.

\section{3.- Miguel de CARVAJAL Y MESÍA, MARQUÉS DE JÓDAR}

- Oidor de la Chancillería de Valladolid, 16-VI-1617.

- Oidor del Consejo de Órdenes, 1-VI-1624. Plaza vacante por promoción de García de Haro al Consejo Real. Juramento: Madrid, 4-VII-1624.

- Consejero de Castilla, 20-VIII-1632. Plaza vacante por fallecimiento de Diego de Corral. Juramento: Madrid, 23-VIII-1632.

\section{4.- Fernando PIZARRO Y DE ORELLANA}

- Fiscal del Consejo de Órdenes, 30-VI-1623. Vacante por promoción de Juan Chumacero de Sotomayor a consejero de Órdenes. Juramento: Madrid, 14-VII-1623.

- Consejero de Órdenes, 18-VII-1626. Vacante por promoción de Juan Coello de Contreras al Consejo de Castilla. Juramento: Madrid, 19-VII-1626.

- Consejero supernumerario de Castilla, 8-I-1633. Juramento: Madrid, 10-I-1633.

- El rey concede a su viuda, Teresa Velasco y Mendoza, mediante cédula de 5-III1651, la merced de por vida de la mitad de los gajes de que gozaba su marido.

\section{5.- Gregorio de TOBAR}

- Fiscal de la Chancillería de Valladolid.

- Alcalde Mayor de Galicia, 1599.

- Oidor de la Chancillería de Granada, 1604.

Hispania, LXIII/2, núm. 214 (2003) 657-744 
- Oidor de ala Chancillería de Valladolid, 1608.

- Consejero de Órdenes, 2-IX-1626. En lugar y por promoción de Juan de Chumacero de Sotomayor al Consejo de Castilla. Juramento: Madrid, 15-X-1626.

- Jubilado: cédula, 19-VIII-1631.

\section{6.- Gaspar de BRACAMONTE, CONDE DE PEÑARANDA}

- Fiscal del Consejo de Órdenes, 31-VII-1626. Plaza vacante por promoción de Fernando Pizarro Orellana al Consejo Real. Juramento: Madrid, 3-VIII-1626.

- Oidor (supernumerario) del Consejo de Órdenes, 13-III-1628. Juramento: Madrid, 13-III-1628. 1634.

- Consejero supernumerario de Castilla, 23-XII-1634. Juramento: Madrid, 26-XII-

- Camarista, 27-IV-1642.

— Presidente del Consejo de Órdenes, 22-II-1651. Juramento: Madrid, 25-II-1651.

\section{7.- Antonio BRICEÑO RONQUILLO}

- Colegial del Colegio de Oviedo de Salamanca.

- Catedrático de Digesto Viejo de la Universidad de Salamanca.

- Oidor de la Chancillería de Valladolid

- Procurador de Cortes por la Universidad de Salamanca.

- Fiscal del Consejo de Órdenes, 1629.

- Oidor del Consejo de Órdenes, 1630. Vacante por fallecimiento de Antonio de Castro y Andrade.

\section{8.- Antonio de LUNA Y SARMIENTO}

- Fiscal del Consejo de Guerra.

- Consejero de Órdenes, 18-IX-1631. Vacante por jubilación de Gregorio de Tovar. Juramento: Madrid, 20-IX-1631.

- Gran Chanciller de Milán, 1635.

- Consejero honorario del Real, 26-I-1643. Juramento: Madrid, 29-I-1643.

- Consejero efectivo del mismo, 22-IV-1651. Juramento: Madrid, 24-IV-1651.

\section{9.- Juan de MENDOZA}

- Bachiller en Cánones por la Universidad de Salamanca.

- Ldo. en Cánones por la Universidad de Sigüenza.

- Juez sinodal.

- Alcalde de Hijosdalgo de la Chancillería de Valladolid.

- Oidor de la Chancillería de Granada, 29-V-1621.

- Consultor del Santo Oficio de la Inquisición de Granada.

- Canónigo de Coria.

- Arcediano de Valencia de Alcántara. 
- Fiscal del Consejo de Órdenes, 1631.

- Oidor del Consejo de Órdenes, 1632.

\section{0.- Manuel Enrique de GUZMÁN}

- Bachiller en Cánones por la Universidad de Salamanca.

- Colegial del Colegio de Santa Cruz de Valladolid.

- Rector de la Universidad de Salamanca.

- Oidor de la Chancillería de Valladolid, 25-V-1628.

- De la Cámara del Cardenal Infante.

- Consejero de Órdenes, 14-II-1633. Vacante por fallecimiento de Juan de Oco.

- Gran Canciller de Milán, 1634.

\section{1.- Sebastián de ZAMBRANA DE VILLALOBOS}

- Fiscal del Consejo y Contaduría Mayor de Hacienda, 15-II-1629. Juramento: Madrid, 4-III-1629.

- Fiscal del Consejo Real, 18-X-1629. Juramento: Madrid, 22-X-1629.

- Consejero de Órdenes, 25-II-1633. En lugar de Fernando Pizarro Orellana, promovido al Consejo de Castilla. Juramento: Madrid, 26-II-1633.

- Consejero supernumerario del Real, 26-IX-1638. Juramento. Madrid, 28-IX-1638.

\section{2.- Diego de ZEBALLOS Y DE LA VEGA}

- Regente del Consejo de Navarra, 29-XI-1624.

- Consejero de Órdenes, VI-1633.

- Consejero supernumerario del Real, 4-I-1642. Juramento: Madrid, 7-I-1642.

\section{3.- Lope de MORALES}

- Del Consejo de Navarra, 1616.

- Oidor de la Chancillería de Valladolid, 11-III-1629. Juramento, 26-IV-1629.

- Corregidor de Vizcaya.

- Procurador de Cortes por la ciudad de Soria.

- Fiscal del Consejo de Órdenes, Madrid, 21-III-1633. Plaza vacante por promoción de Juan de Mendoza a consejero de Órdenes. Juramento: Madrid, 11-IX-1634.

- Consejero (supernumerario) de Órdenes, Madrid, 5-XI-1634. Juramento, Madrid, 7-XI-1634.. V-1642.

- Consejero de Castilla supernumerario, Madrid, 29-I-1642. Juramento, Madrid, 7-

\section{4.- Juan GIRÓN Y ZÚÑIGA}

- Fiscal del Consejo de Guerra, 5-X-1631.

- Consejero de Órdenes, 20-IV-1635.

Hispania, LXIII/2, núm. 214 (2003) 657-744 
- Consejero honorario del Consejo Real, 6-I-1657.

- Consejero efectivo de Castilla, 28-VIII-1660.

\section{5.- Diego RODRÍGUEŻ BALTODANO}

- Colegial del Colegio de San Bartolomé de Salamanca.

- Juez de Grados la Audiencia de Sevilla, IV-1612.

- Consultor del Santo Oficio de la Inquisición de dicha ciudad.

- Oidor de la Chancillería de Valladolid, 15-V-1621.

- Fiscal del Consejo de Órdenes, 11-V- 1635. Vacante por promoción de Lope de Morales a plaza del mismo Consejo. Juramento: Madrid, 18-V-1635.

- Oidor del Consejo de Órdenes, 21-X-1636. Juramento: Madrid, 21-X-1636.

\section{6.-Juan CHACÓN PONCE DE LEÓN}

- Oidor de la Chancillería de Valladolid, 5-X-1631.

- Consejero (supernumerario) de Órdenes, 23-VI-1637. 1644.

- Consejero supernumerario del Real, 6-VIII-1644. Juramento: Madrid, 12-VIII-

_ Visitador General de Nápoles, 1647.

\section{7.- Álvaro de OCA Y ZÚÑIGA}

- Regente del Consejo de Navarra, 19-VI-1633.

- Consejero de Órdenes, IV-1637.

- Consejero de Castilla, .18-XI-1637.

\section{8.- Claudio PIMENTEL}

- Fiscal del Consejo de Órdenes, 11-V-1638. Vacante por promoción de Diego Rodríguez Baltodano a una de las plazas del mismo Consejo. Juramento: Madrid, 31-V1638.

- Consejero de Órdenes, 23-X-1638. Vacante por promoción de Sebastián Zambrana Villalobos al Consejo Real. Juramento: Madrid, 25-X-1638.

- Consejero de la Inquisición, 1642.

\section{9.-Juan de CARBAJAL Y SANDE}

- Colegial del Colegio de Cuenca de Salamanca.

- Regente de la Audiencia de Canarias, 24-III-1624.

- Oidor supernumerario del Consejo de Indias, 17-V-1631. Juramento: Madrid, 24V-1631. Visitador de la Audiencia de Charcas.

- Consejero de Órdenes, 17-I-1640. Juramento: Madrid, 19-I-1640.

- Presidente de la Chancillería de Granada, 22-IV-1644.

- Presidente de la Chancillería de Valladolid, 21-XI-1648. 
- Presidente del Consejo y Contaduría Mayor de Hacienda, 22-XI-1652. Vacante por fallecimiento de Antonio de Camporredondo Río. Juramento: Madrid, 29-XI-1652.

- Plaza del Consejo y de la Cámara de Castilla, 20-III-1658. Juramento: Madrid, 28-III-1658.

\section{0.- Antonio de ARAGÓN}

- Consejero (supernumerario) de Órdenes, 24-IX-1640. Juramento: Madrid, 24IX-1640.

- Consejero de Inquisición, 1640.

\section{1.-Jerónimo de MASCAREÑ $A S$}

- Nacido en Lisboa.

- Oidor (supernumerario) del Consejo de Órdenes, 25-VI-1641. Juramento: Madrid, 26-VI-1641.

- Consejero de Portugal.

- Obispo de Segovia, consagrado el 9-IV-1668.

- Falleció el 25-X-1671.

\section{2.- Bernardo de IPEÑARRIETA Y GALDÓS}

- Oidor de la Chancillería de Valladolid, 7-III-1.631.

- Alcalde de Casa y Corte, decreto, Madrid, 21-VI-1641. No aceptó.

- Consejero (supernumerario) de Órdenes, 27-XI-1641. Juramento: Madrid, 12-VI1642. Cédula, 21-VII-1642, que por estar ocupado en el servicio real se le abone el salario y emolumentos de la plaza del Consejo de Órdenes desde el día que se le expidió el título.

- Consejero de Castilla, 25-XII-1645. Juramento: Madrid, 20-III-1646.

\section{3.- Francisco de BORJA}

- Consejero (supernumerario) de Órdenes, 22-XII-1642. Juramento: Madrid, 23XII-1642.

\section{4.- Pedro de ALARCÓN Y OCÓN}

- Colegial del Colegio de Cuenca en Salamanca.

- Alcalde Mayor del Reino de Navarra, junio de 1618.

- Alcalde del Crimen de la Chancillería de Granada, 8-IX-1624.

- Alcalde del Crimen de la Chancillería de Valladolid, octubre de 1626.

- Corregidor de Asturias y Oidor de la Chancillería de Valladolid, 7-IV-1635.

- Consejero supernumerario de Órdenes, 23-VI-1643. Juramento: Madrid, 25-VI1643.

Hispania, LXIII/2, núm. 214 (2003) 657-744 


\section{5.- Agustín DEL HIERRO}

- Alcalde supernumerario de Casa y Corte, 16-IV-1645. Juramento: Madrid, $17-$ VI-1645.

- Consejero de Órdenes, 6-V-1647. Juramento: Madrid, 16-V-1647.

- Procurador fiscal del Consejo de Castilla, 28-VIII-1648. Juramento: Madrid, 5IX-1648.

\section{6.- Antonio de BENAVIDES} 1647.

- Consejero (supernumerario) de Órdenes, 23-II-1647. Juramento: Madrid, 25-II-

- Comisario General de la Cruzada, 1668.

\section{Diego ZAPATA}

- Oidor de la Chancillería de Granada, 12-IV-1642.

- Fiscal del Consejo de Órdenes, 30-XI-1647. Vacante por promoción de Rodrigo Jerónimo Pacheco a una plaza del Consejo de Indias. Juramento: Madrid, 2-XII-1647.

- Consejero de Órdenes, 1648.

- Gran Canciller de Milán, 1648.

- Consejero de Italia.

- Consejero Real honorario, 15-II-1670. Juramento: Madrid, 5-VII-1670.

- Consejero Real en ejercicio, 11-I-1673. Juramento: Madrid, 11-I-1673.

- Presidente del Consejo y Contaduría mayor de Hacienda y sus Tribunales, 21-XI1673. Juramento: Madrid, 22-XI-1673.

\section{8.- Álvaro de la TORRE IBERNIA}

— Bachiller en Cánones, agosto de 1627.

- Colegial del Colegio mayor de San Bartolomé de Salamanca, septiembre de 1633.

- Ldo., abril de 1640.

- Agente procurador y solicitador en Roma junto con las agencias de los Reinos de Nápoles y Sicilia y del Estado de Milán, 1644.

- Consejero (supernumerario) de Órdenes, 1649.

\section{9.- Marcos TAMARIZ DE LA ESCALERA}

- Juez Mayor de Vizcaya.

- Oidor de la Chancillería de Granada, 7-XI-1631.

- Fiscal del Consejo de Órdenes, 2-VI-1649. Vacante la plaza por promoción de Diego Zapata a consejero de Órdenes. Juramento: Madrid, 3-VI-1649.

- Consejero de Órdenes, 1650. 


\section{0.- Mateo de VILLAMARÍN ROLDÁN}

- Colegial de San Miguel (Granada).

- Alcalde supernumerario del Crimen de la Chancillería de Granada, 28-VI-1636. 1649.

- Alcalde supernumerario de Casa y Corte, 26-XI-1648. Juramento: Granada, 4-I-

- Oidor del Consejo de Órdenes, 5-II-1651. Plaza vacante por fallecimiento de Marcos Tamariz. Juramento: Madrid, 6-II-1651. I- 1652

- Oidor supernumerario del Consejo de Indias, 18-X-1651. Juramento: Madrid, 9-

\section{1.- Pedro de MUNIBE}

- Alcalde supernumerario de Casa y Corte, 4-VI-1646. Juramento: Madrid, 8-VI-1646.

- Consejero (supernumerario) de Órdenes, 5-VI-1651. Juramento: Madrid, 7-VI-1651.

- Consejero supernumerario del Real, 3-III-1653. Madrid, 5-III-1653.

\section{2.- Gregorio de CHAVES MENDOZA}

- Colegial huésped del mayor de Cuenca de Salamanca.

- Catedrático de Leyes de la Universidad de Salamanca.

- Corregidor de Jaén, de Alcalá la Real, de Loja y Alhama y de Córdoba.

- Alcalde de Hijosdalgo de la Chancillería Granada, 15-III-1638.

- Oidor de la Chancillería de Granada, 15-III-1646 1648.

- Alcalde supernumerario de Casa y Corte, 26-XI-1648. Juramento: Madrid, 17-V-

- Consejero de Órdenes, 8-VII-1651. Juramento: Madrid, 10-VII-1651.

\section{3.- Juan de ARCE OTALORA}

- Regente del Consejo de Navarra, 2-IV-1648.

- Consejero de Órdenes; 30-VIII-1652. Juramento: Madrid, 16-VII-1654.

- Oidor supernumerario del Consejo Real, 6-I-1657. Juramento: Madrid, 8-I-1657.

- Del Consejo de Hacienda, por las tardes, 24-V-1666.

\section{4.-Juan de ESTRADA MANRIQUE}

- Mujer: María Francisca Chumacero.

- Alcalde de Hijosdalgo de la Chancillería de Granada, 16-IX-1645.

- Oidor de la Chancillería de Valladolid, 8-X-1648. 1653.

- Consejero (supernumerario) de Órdenes; 30-V-1653. Juramento: Madrid, 23-VI-

- Cédula, 25-I-1661, el rey hace merced a José de Estrada, hijo de Juan de Estrada, o a su viuda, María Francisca Chumacero, de los gajes que gozaba el consejero.

Hispania, LXIII/2, núm. 214 (2003) 657-744 


\section{5.- Miguel de LUNA ARELLANO}

- Alcalde Mayor de la Real Audiencia de Galicia, 1623.

- Juez de la Audiencia de Sevilla.

- Superintendente de la Justicia Militar en Flandes.

- Oidor supernumerario de la Chancillería de Granada, 25-XII-1645.

- Fiscal del Consejo de Órdenes, 25-IV-1653. Plaza vacante por promoción de Vergara a consejero de Órdenes. Juramento: Madrid, 30-IV-1653.

- Consejero de Órdenes, 18-IV-1654. Plaza vacante por fallecimiento de Gregorio de Chaves. Juramento: Madrid, 21-IV-1654.

- Consejero de Indias, 4-IX-1659. Plaza vacante por fallecimiento de Juan de la Calle. Toma de posesión: 6-IX-1659.

- Fallecimiento: 12-V-1662.

\section{6.- Antonio de RIAÑO SALAMANCA}

- Oidor de la Chancillería de Valladolid, 16-III-1650.

- Fiscal de Consejo de Órdenes, 10-VII-1654. Vacante por promoción de Miguel de Luna y Arellano a una de las plazas del mismo Consejo. Juramento: Madrid, 20-VII-1654. 1656.

- Consejero (supernumerario) de Órdenes, 10-VI-1656. Juramento: Madrid, 13-VI-

- Consejero Real, 7-I-1671. Juramento: Madrid, 9-I-1671.

\section{7.- Bernabé de ANDRADE Y FUNES}

- Oidor de la Chancillería de Valladolid, 15-V-1641.

- Alcalde de Casa y Corte, 1651.

- Consejero de Órdenes, 1657.

\section{8.- Fernando de ARCE DÁVILA}

- Oidor de la Chancillería de Granada, 10-VI-1653.

- Fiscal del Consejo de Órdenes, 4-VII-1656. Vacante por promoción de Antonio de Riaño y Salamanca a una plaza de consejero de Órdenes. Juramento: Madrid, 3-VIII-1656.

- Consejero de Órdenes, 17-I-1657. Vacante por promoción de Francisco de Vergara a fiscal del Consejo de Castilla. Juramento: Madrid, 17-I-1657.

- Consejero de Castilla, 8-I-1672. Juramento: Madrid, 11-I-1672.

\section{9.- Francisco de VERGARA ÁLAVA}

- Oidor de la Chancillería de Granada, 1-IV-1645.

- Fiscal del Consejo de Órdenes, 2-II-1652. vacante por promoción de José Pardo de Figueroa a la fiscalía del Consejo de Indias. Juramento: Madrid, 5-II-1652.

- Consejero de Órdenes, 1653.

— Fiscal del Consejo Real, 12-I-1657. Juramento, 13-I-1657.

- Oidor supernumerario del Consejo Real, 10-I-1659. Juramento: 10-I-1659.

Hispania, LXIII/2, núm. 214 (2003) 657-744 


\section{0.- JUan RAMÍREZ DE ARELLANO} 1657

- Alcalde supernumerario de Casa y Corte, 7-XI-1657. Juramento: Madrid, 8-XI1659.

- Consejero (supernumerario) de Órdenes, 13-II-1659. Juramento: Madrid, 14-II-

- Consejero de Indias, 4-X-1660. Vacante por promoción de Fernando de Guevara Altamirano al Consejo Real. Juramento: Madrid, 7-X-1660.

— Consejero de Castilla, 8-I-1672. Juramento: Madrid, 11-I-1672.

\section{1.-Juan GOLFÍN DE CARVAJAL}

- Oidor de la Chancillería de Granada, 26-IX-1647. 1659.

- Consejero (supernumerario) de Órdenes, 10-V-1659. Juramento: Madrid, 12-V-

- Consejero de Castilla, 30-I-1664. Juramento: Madrid, 31-I-1664.

\section{2.- Baltasar de LA CUEVA ENRÍQUEZ}

- Oidor de la Chancillería de Granada, 5-VII-1654.

- Fiscal del Consejo de Órdenes, 8-III-1659. Vacante por promoción de Gil de Castrejón a fiscal del Consejo de Indias. Juramento: Madrid, 4-IV-1659.

- Consejero de Órdenes, 7-IX-1659. Vacante por promoción de Miguel Luna y Arellano a consejero de Indias. Juramento: Madrid, 13-IX-1659.

\section{3.- Lope de los Ríos}

- Regente del Consejo de Navarra, 13-XII-1658.

- Consejero ( supernumerario) de Órdenes, 30-VI-1661. Posesión: Madrid, 19-IX-1661.

- Presidente de la Chancillería de Granada, 15-V-1662.

\section{4.- Gabriel de CHAVES SOTOMAYOR}

- Oidor de la Chancillería de Valladolid, 8-V-1653.

- Fiscal del Consejo de Órdenes, 12-XII-1659. Vacante por promoción de Baltasar de la Cueva al Consejo de Órdenes. Juramento: Madrid, 19-XII-1659.

- Consejero de Órdenes, 1660. Vacante por promoción de Ramírez de Arellano a consejero de capa y espada de Indias.

- Consejero Real, 3-V-1664. Juramento: Madrid, 9-V-1664.

\section{5.- Jerónimo de MORQUECHO SANDOVAL}

- Fiscal del Consejo de la Cruzada, 28-XI-1651.

- Fiscal del Consejo de Órdenes, 3-III-1661. Vacante por promoción de Gabriel de Chaves Sotomayor al Consejo de Órdenes. Juramento: Madrid, 4-III-1661.

Hispania, LXIII/2, núm. 214 (2003) 657-744 
- Consejero de Órdenes, 21-VII-1662. Vacante por promoción de Lope de los Ríos a Presidente de la Chancillería de Granada. Juramento: Madrid, 21-VII-1662.

- Consejero del Real, 8-I-1672. Juramento: Madrid, 11.I-1672.

\section{6.- Francisco de MEDRANO BAZÁN} 1653.

- Alcalde de Casa y Corte supernumerario, 29-V-1653. Juramento: Madrid, 8-VI-

- Oidor del Consejo de Órdenes, 23-III-1664. En lugar y por promoción de Juan Golfín al Consejo Real. Juramento: Madrid, 28-III-1664.

- Fiscal del Consejo Real, 10-IX-1668. Juramento: Madrid, 13-IX-1668.

- Consejero de Castilla, 6-I-1670. Juramento: 10-I-1670.

\section{7.-Jerónimo de PRADO Y TOLEDO}

- Alcalde Mayor de Galicia, 23-IX-1654.

- Oidor de la Chancillería de Valladolid, 30-V-1659.

- Fiscal de la Cárcel de Corte y Audiencia de los alcaldes de Corte: 2-XII-1661. Juramento: Madrid, 9-XII-1661.

- Fiscal del Consejo de Órdenes, 17-VIII-1662. Vacante por promoción de Gerónimo Morquecho a plaza del Consejo de Órdenes. Juramento: Madrid, 19-VIII-1662.

- Oidor (supernumerario) de Órdenes, 1664.

- Consejero Real de Castilla, 23-IV-1672 Juramento: Madrid, 29-IV-1672.

\section{8.- Gonzalo de FERNÁNDEZ DE CÓRDOVA}

- Oidor de la Chancillería de Valladolid, 19-X-1659.

- Consejero (supernumerario) de Órdenes, 27-XI-1664. Juramento: Madrid, 10XII-1664.

- Consejero Real, 15-I-1671. Juramento: Madrid, 16-I-1671.

- Presidente de la Casa de Contratación, 27-V-1672.

- Presidente del Consejo y Contaduría Mayor de Hacienda, 4-IV-1677. Juramento: Madrid, 5-IV-1677. Exonerado: 17-VII-1677.

\section{9.- Antonio de URRUTIA AGUIRRE}

- Oidor de la Chancillería de Granada, 30-IX-1660.

- Fisal de la cárcel real y Audiencia de los alcaldes de Casa y Corte, 10-IX-1662. Vacante por promoción de Gerónimo de Prado y Toledo a fiscal del Consejo de Órdenes. Juramento: Madrid, 5-X-1662.

- Fiscal del Consejo de Órdenes, 5-VI-1664. Vacante por promoción de Gerónimo de Prado a una plaza del mismo Consejo. Juramento: Madrid, 9-VI-1664.

- Consejero (supernumerario) de Ordenes, 15-VII-1665. Juramento: Madrid, 23VII-1665.

— Fallecimiento, 1668.

Hispania, LXIII/2, núm. 214 (2003) 657-744 


\section{III.- REINADO DE CARLOS II}

\section{1.- Fernando QUEIPO DE LLANO VALDÉS}

- Juez Mayor de Vizcaya.

- Oidor de la Chancillería de Granada, 26-XI-1648.

- Fiscal del Consejo de Órdenes, 18-XI-1665. Vacante por promoción de Urrutia a consejero de Órdenes. Juramento: Madrid, 19-XI-1665.

- Consejero de Ordenes, 16-VII-1667. Juramento: Madrid, 18-VII-1667.

- Por cédula 7-X-1667 el monarca hizo merced a su viuda Felipa Zapata de la mitad de los gajes que su marido gozaba.

\section{2.-José PONCE DE LEÓN}

- Oidor de la Chancillería de Valladolid, 22-X-1667.

- Fiscal del Consejo de Órdenes, 8-XII-1668. Vacante por haber pasado Melchor de Córdoba Zapata a fiscal del Consejo de Indias. Juramento: Madrid, 10-XII-1668.

- Consejero de Órdenes, 14-II-1669. Juramento: Madrid, 16-II-1669.

- Consejero de Indias, 12-XI-1671. Vacante por promoción de Lorenzo Matheu y Sanz a regente del Consejo de Aragón. Juramento: Madrid, 14-XI-1671.

- Camarista de Indias, 27-VI-1673.

- Fallecimiento: 3-VII-1676.

\section{3.- Jerónimo RAMOS DE MANZANO} Carlos II.

- Hijo de Francisco Ramos del Manzano, del Consejo y Cámara y maestro del rey

- Oidor supernumerario dé la Chancillería de Valladolid, 29-X-1669.

- Fiscal del Consejo de Órdenes, 20-II-1670. Vacante por promoción de Antonio Sevil Santelices a fiscal del Consejo de Indias. Juramento: Madrid, 25-II-1670.

- Consejero de Órdenes, 13-1-1671. Vacante por promoción de Antonio de Riaño y Salamanca al Consejo Real. Juramento: Madrid, 14-I-1671.

- Consejero honorario de Castilla, «sin exercicio ni gajes» 21-XI-1673. Juramento: Madrid, 23-XI-1673.

— Consejero efectivo de Castilla, 13-VIII-1679. Posesión: Madrid, 14-VIII-1679.

\section{4.- Gabriel MENÉNDEZ DE PORRES Y AVILÉS, CONDE DE CANALEJAS}

- Juez de la Audiencia de Sevilla.

- Oidor de la Chancillería de Granada, 4-IX-1665.

- Alcalde supernumerario de Casa y Corte, 9-XI-1668. Juramento: Madrid, 19-XI1668.

- Consejero de Órdenes, 6-IV-1671. Vacante por promoción de Gonzalo de Córdoba al Consejo de Castilla. Juramento: Madrid, 6-IV-1671. Salario: 500.000 mrs.

- Consejero de Indias, 20-X-1675. Juramento: 24-X-1675.

- Camarista de Indias, 28-IX-1685. Juramento: 1-X-1685. Salario: 50.000 mrs. 


\section{5.- Pedro de ULLOA GOLFÍN}

- Oidor de la Chancillería de Granada, 19-I-1661

- Fiscal del Consejo de Órdenes, 19-III-1671. Vacante por promoción de Jerónimo Miguel Ramos del Manzano al Consejo de Órdenes: Juramento: Madrid, 11-V-1671.

- Consejero de Órdenes, 1671.

- Consejero Real, 30-XI-1673. Juramento: Madrid, 2-XII-1673.

\section{6.- Juan de ORDÓNEEZ RODRÍGUEZ DE LEDESMA}

- Colegial mayor y catedrático en Salamanca.

- Juez de Grados de la Audiencia de Sevilla,

- Oidor de la Chancillería de Valladolid, 20-II-1661

- Fiscal del Consejo de Guerra, 10-III-1664. Vacante por fallecimiento de Íñigo López Bravo. Juramento: Madrid, 17-III-1664.

- Consejero de Órdenes, 29-III-1672. Juramento: Madrid, 31-III-1672.

\section{7.- Rodrigo Jerónimo PORTOCARRERO MENESES NOREÑA}

- Oidor de la Chancillería de Granada, 12-VIII-1670.

- Fiscal del Consejo de Órdenes, I-1672.

- Consejero de Órdenes, 3-VI-1672. Juramento: Madrid, 20-VI-1672.

- Consejero de Castilla, 4-X-1680.

\section{8.- Carlos de VILLAMAYOR VIVERO}

- Regente del Consejo de Navarra, 8-IV-1669.

- Consejero de Órdenes, 5-IX-1672. Juramento: Madrid, 6-IX-1672.

- Consejero de Indias, 4-XII-1673. Juramento: Madrid, 6-XII-1673.

- Presidente de la Chancillería de Granada y consejero real, 1-III-1675. Juramento como consejero: Madrid, 16-III-1675.

\section{9.- Cristóbal del CORRAL IPEÑARRIETA}

- Oidor de la Chancillería de Granada, 14-VII-1664.

- Fiscal del Consejo de Órdenes, 10-VI-1672. Vacante por promoción de Rodrigo Portocarrero a una plaza del mismo Consejo. Juramento: Madrid, 13-VI-1672.

- Consejero de Órdenes, 26-V-1673. Vacante por fallecimiento de Juan Ordóñez Rodríguez de Ledesma. Juramento: Madrid, 29-V-1673.

- Consejero de Castilla, 23-VI-1676. Juramento: Madrid, 25-VI-1676.

\section{0.- Luis de SALCEDO ARBIZU, CONDE DE GÓMARA}

- Alcalde de Casa y Corte, 20-III-1670.

- Consejero de Órdenes, 9-I-1674. Juramento: Madrid, 11-I-1674 
- Consejero Real, 2-VIII-1681. Juramento: Madrid, 7-VIII-1681

- Camarista, 12-I-1688. Toma de posesión: 15-I-1688.

\section{1.- Pedro SARMIENTO TOLEDO, CONDE DE GONDOMAR, MARQUÉS DE MONTALBO}

- Fiscal del Consejo de Guerra, 20-II-1673. Juramento: 17-IV-1673.

- Fiscal del Consejo de Órdenes, 21-VII-1673. Vacante por promoción de Cristóbal del Corral Ipeñarrieta al Consejo de Órdenes. Juramento: Madrid, 26-VII-1673.

- Consejero de Órdenes, 12-XII-1673. Vacante por promoción de Carlos de Villamayor a plaza del Consejo de Indias.. Juramento: 16-XII- 1673.

— Fiscal del Consejo Real, 28-X-1678. Juramento: Madrid, 30-X-1678.

- Consejero Real, 18-VII-1679.

- Concede la propiedad y perpetuidad de la vara de alguacil mayor del Consejo de Hacienda y de sus tribunales para «después de los días» de Miguel de Ibarra «a quien toca vitaliciamente» (Título, 12-XI-1707).

\section{2.- Melchor de CEBALLOS ELCABALLERO}

- Oidor de la Chancillería de Valladolid, 6-III-1671.

— Fiscal de la cárcel de Corte, 22-VIII-1672. Juramento: Madrid, 28-IX-1672.

- Consejero de Órdenes supernumerario, 8-II-1675. Juramento: Madrid, 21-II-1675.

- Consejero de Castilla honorario, 25-V-1683. Juramento: 29-V-1683.

\section{3.- Jerónimo de VILLAMAYOR}

- Fiscal del Consejo de la Cruzada, 17-X-1667.

— Fiscal del Consejo de Órdenes, 22-III-1674.

- Consejero de Órdenes, 10-XI-1675.

- Consejero Real, 22-VIII-1681.

\section{4.- Manuel de COLOMA}

- Hijo de Pedro Coloma, Secretario del Despacho Universal.

- Alcalde de Hijosdalgo de la Chancillería de Valladolid.

- Oidor de la Chancillería de Granada, 9-III-1671.

- Fiscal del Consejo de Guerra, 28-VII-1673. Juramento: 11-VIII-1673.

- Consejero de Órdenes supernumerario, 11-II-1677. Juramento: 17-II-1677.

- Consejero honorario de Castilla, 5-XI-1684. Juramento: en Milán el 3-I-1685 en manos del conde de Melgar, Gobernador y Capitán General del Estado de Milán.

\section{5.- Alonso ESCUDERO ERASO}

- Alcalde Mayor de Galicia, 19-X-1659

- Oidor de la Chancillería de Valladolid, 24-XII-1665.

Hispania, LXIII/2, núm. 214 (2003) 657-744 
- Del Consejo de Navarra, 1672.

- Fiscal del Consejo de Órdenes, 14-IV-1676. Vacante por promoción de Jerónimo de Villamayor a consejero de Órdenes. Juramento: Madrid, 21-IV-1676.

— Oidor del Consejo de Órdenes, 1678.

\section{6.- Francisco MOSCOSO OSORIO}

- Arcediano de Madrid y sumiller de cortina del rey. 1678 .

- Consejero de Órdenes, por resolución a consulta de la Cámara de 18 de enero de

\section{7.- Andrés de RIAÑO}

- Fiscal de la Junta de Millones.

- Oidor supernumerario del Consejo y Contaduría Mayor de Hacienda, 21-XII1653. Juramento: Madrid, 23-XII-1653.

- Consejero de Órdenes, 6-VI-1679. Juramento: Madrid, 7-VI-1679.

\section{8.- Alonso de AGUILAR}

- Colegial del Mayor de Cuenca.

- Fiscal del Consejo de Órdenes, 24-I-1678. Vacante por promoción de Escudero a consejero de Órdenes. Juramento: Madrid, 24-I-1678.

- Consejero de Ordenes, 15-XII-1679. Juramento: Madrid, 15-XII-1679.

\section{9.- Isidro de CAMARGO GUZMÁN}

- Alcalde de Casa y Corte, 31-XII-1677. Juramento: Madrid, 8-VIII-1678.

- Consejero de Órdenes, 19-XII-1680. En lugar y por promoción de Rodrigo Portocarrero al Consejo de Castilla. Juramento: Madrid, 21-I-1681.

- Consejero Real, 15-I-1684. Juramento: 22-I-1684.

\section{0.- Luis de CAÑAS SILVA}

- Alcalde de Hijosdalgo de la Chancillería de Valladolid.

- Oidor de la Chancillería de Valladolid, 22-VIII-1664.

- Fiscal del Consejo de Guerra, 14-IV-1677. Juramento: Madrid, 14-VI-1677.

- Fiscal del Consejo de Órdenes, 8-IV-1680. Juramento: Madrid, 10-IV-1689.

- Consejero de Indias, 5-XI-1680.

- Consejero de Órdenes, 5-XI-1680. Juramento: Madrid, 7-XI-1680.

\section{1.-JUan RAMÍREZ DE BAQUEDANO, MARQUÉS DE ANDIA}

— Alcalde de Casa y Corte, 7-X-1687. 
- Consejero de Órdenes. Consulta del Consejo de la Cámara: 2-V-1695. Título: 21V-1695.

- Consejero de Castilla, 29-VI-1700.

\section{2.- Alonso RICO DE VILLARROEL}

- Consejero de Órdenes. Decreto de nombramiento: 20-I-1681. Título: 23-IV1681.

\section{3. - EL CONDE DE MONTEZUMA}

- Oidor de la Chancillería de Granada.

- Consejero de Órdenes. Decreto de nombramiento: 24-VI-1681.

\section{4.- Baltasar de MENDOZA Y SANDOVAL}

- Oidor de la Chancillería de Granada.

- Consejero de Órdenes supernumerario. Decreto de nombramiento: 10-X-1681. Título: 29-I-1682.

\section{5.- Francisco BERNARDO DE QUIRÓS}

- Agente General en Roma.

- Consejero supernumerario de Órdenes. Decreto de nombramiento: 31-V-1684. Título: 20-XI-1687.

- Consejero de Castilla. Título: 16-III-1692.

- Consejero y camarista de Indias. Título: 18-III-1700.

\section{6.- Antonio SARMIENTO TOLEDO}

- Oidor de la Chancillería de Granada. 1680.

- Consejero supernumerario de Órdenes. Decreto de nombramiento: 8-I-1686. Título: 21-VI-1686.

\section{7.- Antonio PORTOCARRERO, CONDE DE OBEDOS}

- Consejero de Órdenes. Decreto de nombramiento: 20-VIII-1686.

\section{8.- Luis Francisco VILLAMARÍN Y ORTEGA}

- Fiscal de la Chancillería de Granada. Título: 23-I-1673.

- Oidor de la Chancillería de Granada. Título: 25-X-1675.

- Fiscal del Consejo de Órdenes.

- Consejero de Órdenes. Decreto de nombramiento: 14-I-1687.

Hispania, LXIII/2, núm. 214 (2003) 657-744 


\section{9.- García de MEDRANO Y MENDIZÁBAL}

- Alcalde de Hijosdalgo de la Chancillería de Valladolid.

- Oidor de la Chancillería de Valladolid. Título: 4-X-1680.

- Alcalde de Casa y Corte. 1684.

- Consejero supernumerario de Órdenes. Decreto de nombramiento: 23-V-1690. Título: 17-VIII-1690.

\section{0.- Rodrigo de MIRANDA Y QUIÑONES, CONDE DE SAN PEDRO}

- Alcalde de Casa y Corte, 8-IV-1685.

- Consejero supernumerario de Órdenes. Decreto de nombramiento: 23-V-1690. Título: 11-VII-1690.

- Consejero de Castilla, 19-I-1693.

\section{1.-Nicolás de ORELLANA}

— Fiscal del Consejo de Órdenes. 1695.

- Consejero de Órdenes. Decreto de nombramiento: 21-XI-1695. Título: 14-XII-

- Jubilado: 3-XI-1707.

\section{2.- Ignacio de ZÁRATE}

- Fiscal del Consejo de Guerra.

- Consejero de Órdenes. Decreto de nombramiento: 21-XI-1695.

\section{3.- Pedro QUEIPO DE LLANO}

- Fiscal de la Chancillería de Granada, 25-XI-1679.

- Oidor de la Chancillería de Granada, 11-III-1686.

- Alcalde de Casa y Corte, 20-VI-1695. VI-1697.

- Consejero de Órdenes. Consulta del Consejo de la Cámara: 3-VI-1697. Título: 20-

- Presidente de la Chancillería de Valladolid,, 21-X-1697.

- Consejero de Castilla, 16-V-1700.

\section{4.-Juan de CHALAR} 1697.

- Consejero supernumerario de Órdenes. Consulta del Consejo de la Cámara: 3-VI-

\section{5.- Carlos de BORJA}

- Sumiller de Cortina. 
- Consejero supernumerario de Órdenes. Decreto de nombramiento: 30-XII-1697. Título 28-I-1698.

\section{6.- Cristóbal de CHAVES}

- Alcalde de Hijosdalgo de la Chancillería de Valladolid. Título: 18-V-1686.

- Oidor de la Chancillería de Valladolid. Título: 27-IV-1693.

- Alcalde de Casa y Corte. Título: 3-XII-1696.

- Consejero supernumerarió de Órdenes. Consulta del Consejo de la Cámara: 9-XII1697. Título: 9-I-1698.

\section{7.- Francisco de CEVALLOS EL CAVALLERO}

- Fiscal de la Chancillería de Granada. Título: 10-XII-1688.

- Oidor de la Chancillería de Granada. Título: 2-IV-1691.

- Consejero de Órdenes. Consulta del Consejo de la Cámara: 9-XII-1697. Título: 20-II-1698.

\section{8.- Andrés DORIGA}

- Fiscal del Consejo de Guerra. Título: 29-XII-1696.

- Consejero supernumerario de Órdenes. Decreto de nombramiento: 29-X-1698. Título: 9-XII-1698.

\section{9.- Mateo IBÁÑEZ DE MENDOZA}

- Oidor de la Chancillería de Granada. Título: 26-X-1690.

- Fiscal del Consejo de Órdenes.

- Consejero de Órdenes. Consulta del Consejo de la Cámara: 7-VII-1700.

\section{Fuentes:}

AGS, QC, legs. 1-39; AHN, Consejos, leg. 51.708 y Estado, legs. 6406 y 6408. 